SONISE DOS SANTOS MEDEIROS

\title{
REPRESENTAÇÕES E PRÁTICAS TRADICIONAIS DIANTE DA INOVAÇÃO TECNOLÓGICA: DIMENSÕES SOCIOAMBIENTAIS DO CASO DA PECUÁRIA BOVINA DE LEITE
}

\begin{abstract}
Dissertação de Mestrado apresentada à Escola de Engenharia de São Carlos da Universidade de São Paulo, como parte dos requisitos necessários à obtenção do título de Mestre em Ciências da Engenharia Ambiental.
\end{abstract}

Orientadora: Prof ${ }^{a}$ Drª Norma Felicidade Lopes da Silva Valencio

São Carlos - SP 


\section{FOLHA DE. JULGAMENTO}

Candidata: Bacharel SONISE DOS SANTOS MEDEIROS

Dissertação defendida e julgada em 29/02/2008 perante a Comissåo Julgadora:

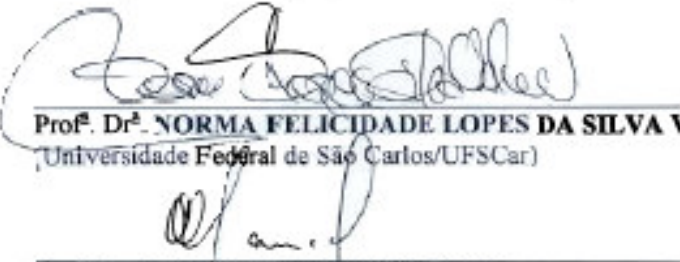

Prof. Dr. FREDERICO FABIO MAUAD

(Escola de Engenharia de Săo Carlos/USP)
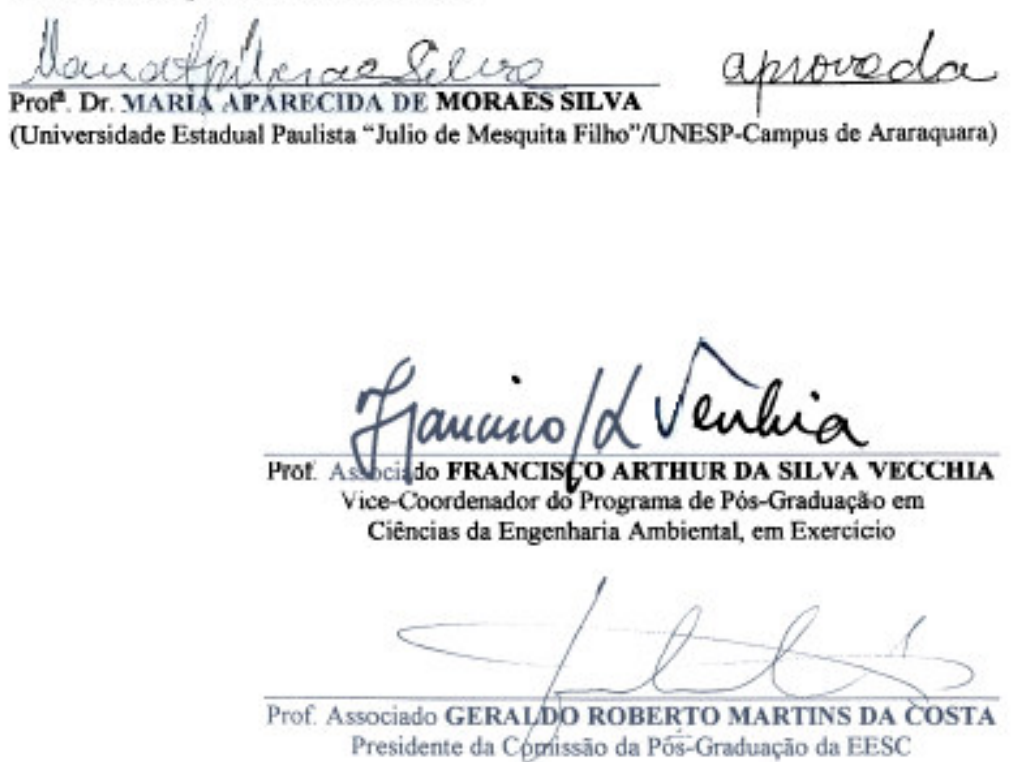
Norma,

minha extrema gratidão e admiração. 


\section{AGRADECIMENTOS}

Aos meus pais, pela oportunidade da vida.

À EMBRAPA, por ter viabilizado esta experiência.

À Embrapa Pecuária Sudeste, nas pessoas do Dr. Nelson, Dr. Airton e Dr. Sérgio pela confiança e também oportunidade.

Ao professor Dr. Silvio Crestana, de forma muito especial, por suas valiosas contribuições.

Ao professor Dr. Frederico Mauad pela colaboração e também importantes contribuições.

Aos colegas de trabalho pela atenção, colaboração e disponibilidade quando das entrevistas.

Aos agricultores familiares que me receberam com muita receptividade e cordialidade.

Ao Douglas, Mário Augusto e Zildinha, do município de Cristais Paulista-SP, pelo apoio e a atenção que me dispensaram.

Às amigas Elaine e Denise pelo apoio e colaboração.

Ao Carlos Eduardo pela leitura e contribuições a este trabalho.

Aos colegas do SRH pelo apoio e incentivo.

A Sônia Borges, Rosely e Cristina Campanelli, sempre tão atenciosas às minhas solicitações.

Ao colega Jorge Reti por compartilhar seus conhecimentos.

Aos amigos Kátia e Edilson pelo apoio logístico.

Por fim, aos meus amigos que, de perto ou à distância, me incentivaram e torceram por mim. 


\section{RESUMO}

MEDEIROS, S. S. Representações e práticas tradicionais diante da inovação tecnológica: dimensões socioambientais do caso da pecuária bovina de leite, São Carlos, SP, 2008.

A presente proposta de trabalho, está baseada na Teoria das Representações Sociais (TRS), cujos fundamentos permitiram a compreensão da dinâmica e da qualidade das interações, entre a Embrapa Pecuária Sudeste - como instituição pública de pesquisa agropecuária e representante da modernidade e os agricultores familiares, da pecuária de leite dos municípios de Cristais Paulista-SP e Ribeirão Corrente-SP - representando o modo de vida da tradição - no processo de inovação tecnológica por meio do projeto "Balde Cheio". Este estudo buscou preencher uma lacuna de conhecimentos das representações e práticas sociais que são costuradas e produzidas nas interações cotidianas dos atores envolvidos, por meio da análise sociológica baseada num estudo de caso elaborado com procedimentos de pesquisa qualitativa. Analisou-se, em primeiro lugar, o papel do Estado como indutor e viabilizador da modernização da agricultura, privilegiando o capital em detrimento da pequena produção. Após, analisou-se, a implantação da empresa pública de pesquisa agropecuária, Embrapa, a qual constituiu-se, entre outros, na materialização dessa intervenção, o que a caracteriza como uma instituição da modernidade. O grupo com o qual a empresa pública ensejou interagir - agricultura familiar - revelou um modo de vida cujas relações e práticas sociais são baseadas na tradição, mas com paulatina permeabilidade às práticas modernas, incorporadas ambiguamente, isto é, em meio a resistências, como forma de manutenção da sua identidade, e em meio à satisfação pela acomodação dos novos conhecimentos trazidos pela Embrapa. Assim, a análise da construção social e material dos processos interativos entre os sujeitos envolvidos, no caso, a instituição pública e a agricultura familiar, possibilitou evidenciar aspectos significativos a respeito da qualidade desse processo, os quais revelaram tensões subjacentes que sugerem a ausência de uma efetiva dialogicidade.

Palavras-chave: Representações Sociais, Tradição, Modernidade, Agricultura Familiar, Embrapa. 


\begin{abstract}
MEDEIROS, S. S. Traditional representations and practices before the technological innovation: socioenvironmental dimensions of the case of the bovine cattle-breeding of milk, São Carlos, SP, 2008.

This current proposal of work is based on the Social Representation Theories (SRT), whose basis allowed the comprehension of the dynamic and the quality of the interactions between Embrapa Pecuária Sudeste - as a public institution of agricultural cattle-breeding research and a representative of the modernity - and the familiar agriculturists of milk cattle-breeding from cities of Cristais Paulistas-SP and Ribeirão Corrente-SP - representing the tradition way of life - in the process of technological innovation through the project "Balde Cheio". This work sought to fill the gap of the knowledge of the representation and the social practices which are sewed and produced in the everyday interaction of the people involved, through the sociological analyses, based on a case study elaborated with the qualitative research procedures. First of all, it was analyzed, the role of the Estate as a persuader and accomplisher of the modernization of the agriculture, supporting the capital instead of the small production. After, it was analyzed, the implantation of the public agricultural cattle-breeding research institution, Embrapa, which was used, among others, in the materialization of this intervention, that makes it as an institution of the modernity. The group whom the public institution wanted to interact with - familiar agriculture revealed a way of life which the social relations and practices are based on the tradition, but with slowly acceptance of the modern practices, incorporated with both; in other words between the resistance, as a way to keep the identity, and between the satisfaction by the acceptance of the new knowledge brought by Embrapa. Thus, the analysis of the social construction and the interactive process material among the subjects involved, in this case, the public institution and the familiar agriculture, permitted to show meaningful aspects regarding the quality of the process which revealed covered tensions that suggest the absence of an effective dialogicity (change of knowledge).
\end{abstract}

Key-words: Social Representations, Tradition, Modernity, Familiar Agriculture, Embrapa. 


\section{LISTA DE FOTOGRAFIAS}

Foto 1 - produtor em sua rotina de trabalho. A postura de cócoras ao realizar a ordenha manual 25

Foto 2 - tanque de expansão, instalado no espaço da propriedade, para acondicionamento do leite, até o momento da entrega ao caminhão da cooperativa.

Foto 3 - um camponês, circunscrito a seu meio 88

Foto 4 - os meios materiais no campo vão da tração animal à mecanização, definindo diversos níveis de assimilação das inovações voltadas para o meio rural

Foto 5 - família e trabalho: aspectos indissociáveis do modo de vida da tradição 92

Foto 6 - local de trabalho e de residência: presença do técnico da cooperativa e horta doméstica para consumo da família 93

Foto 7 - motor antigo adaptado ao tanque de expansão - forma de reduzir custo, economia de dois mil e oitocentos litros de leite 97

Foto 8 - uso do latão (tradicional) e o resfriador (moderno) para acondicionamento do leite 119

Foto 9 - área de irrigação de capim feita conforme recomendação da Embrapa ao produtor.

Foto 10 - folhas de jornal presas ao suporte do equipamento da ordenha; são utilizadas para secar o úbere da vaca antes da ordenha 124

Foto 11 - quadro técnico para anotações afixado na parede da casa do produtor participante do projeto 126

Foto 12 - local da nascente na propriedade do agricultor familiar, protegida 
por uma vegetação nativa 128

Foto 13 - produtor realizando a ordenha manual, uma prática da tradição, para em seguida, acondicionar o leite no tanque de expansão, uma prática moderna 138 


\section{LISTA DE FIGURAS}

Figura 1: quadro esquemático dos atores envolvidos na análise......... 19

Figura 2: quadro esquemático do procedimento de análise ............... 106 


\section{SUMÁRIO}

\section{RESUMO}

\section{ABSTRACT}

INTRODUÇÃO 9

CAPÍTULO 1 - CARACTERÍSTICAS DA MODERNIDADE................................ 20

1.1. A modernidade como produção material da existência social ..................... 27

1.2. A modernidade como produção simbólica da existência social...................... 32

1.3. A modernidade como lógica das interações sociais.................................... 35

1.4. Inovação como rede sociotécnica ....................................................... 41

1.5. Representações sociais sobre a modernidade........................................ 45

1.6. A modernidade e suas implicações no mundo rural ................................... 50

\section{CAPÍTULO 2 - A EMBRAPA PECUÁRIA SUDESTE: UMA INSTITUIÇÃO DA}

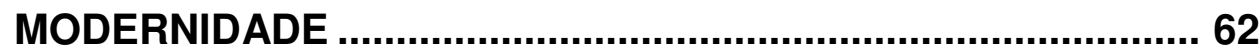

2.1. Contexto do novo desenho institucional para a agricultura brasileira:

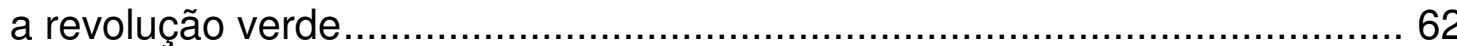

2.2. Implantação da Embrapa: origem e caracterização da instituição ................. 70

2.3. A Embrapa Pecuária Sudeste: missão institucional e estratégias ................. 80

CAPÍTULO 3 - AGRICULTURA FAMILIAR: UM MODO DE VIDA ..................... 87

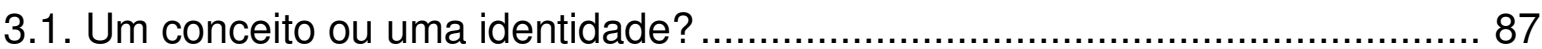

3.2. Estratégias de reprodução material: práticas e significados ........................ 96 


\section{CAPÍTULO 4 - AS PRÁTICAS E REPRESENTAÇÕES TRADICIONAIS FRENTE}

\section{À INOVAÇÃO: LIMITES E POTENCIALIDADES ....................... 102}

4.1. Discussão dos procedimentos do estudo de caso ..................................... 103

4.1.1. O outro no olhar dos sujeitos envolvidos: apontando a qualidade das

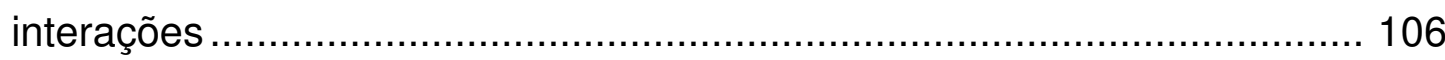

4.1.2. A produção material do agricultor familiar: valorização ou depreciação? ... 115

4.1.2.1 As práticas de produção: dimensões objetivas da resistência e

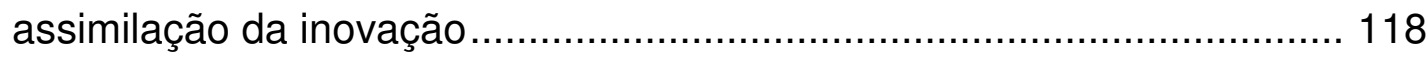

4.1.2.2 A propriedade familiar como produção social do lugar ............................ 124

4.1.2.3 Produção familiar e sua interação com o mercado: a inovação como ponte desejada/eficaz?

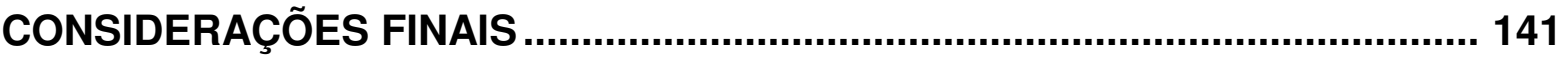

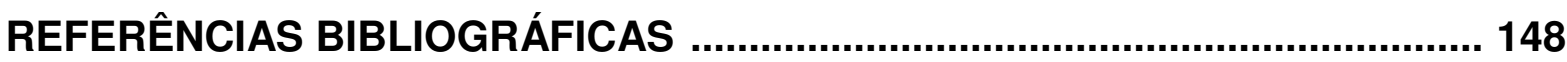

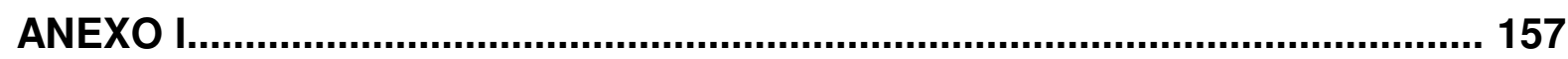

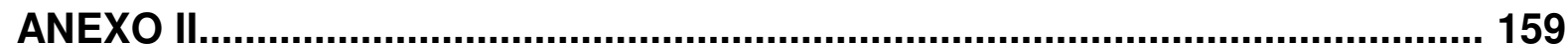




\section{INTRODUÇÃO}

A Embrapa Pecuária Sudeste - empresa pública de pesquisa agropecuária, tem por finalidade produzir tecnologias que promovam a competitividade e o desenvolvimento da pecuária da região Sudeste e estabelece, em seu Plano Diretor, orientações para ações frente aos desafios futuros, para o desenvolvimento sustentável do espaço rural e a competitividade da pecuária bovina de leite.

Em termos sociais, a Unidade busca a redução dos desequilíbrios regionais e desigualdades sociais para a gestão sustentável do meio ambiente e dos recursos naturais. Internamente, propõe como diretriz estratégica de desenvolvimento organizacional e de gestão de pessoas, ações e metas que viabilizem e efetivem a sua missão: "Viabilizar soluções tecnológicas competitivas para o desenvolvimento da pecuária da região Sudeste, por meio da geração, da adaptação e da transferência de conhecimentos e tecnologias em benefício da sociedade" (EMBRAPA, 2005:21).

Entretanto, a geração de novas tecnologias deve garantir não apenas o crescimento do setor produtivo, mas a sua sustentabilidade; esta não somente nos aspectos dos recursos naturais, mas pela efetiva participação dos diferentes e diversos personagens envolvidos, para que se garanta a estes, a identidade do produto ou processo com o seu local e o direito de se fazer representado no produto do conhecimento gerado, seja na sua forma escrita, seja na acessibilidade, seja na apropriação do conhecimento; fortalecendo o sentimento de pertencer e gerando compromisso e comprometimento.

Crê-se que o diálogo entre os agentes integrantes do processo de construção da inovação tecnológica possa minimizar os efeitos não esperados que por ventura ocorram e, assim, ao invés de produzir um distanciamento entre a realidade e os resultados desejados, promovam a sua aproximação.

Convém, contudo, destacar que o processo de produção do conhecimento e sua incorporação, na forma de inovação de produtos e processos, passa pela dimensão da subjetividade e a Teoria das Representações Sociais - TRS, colabora na interpretação de fenômenos nos quais as inovações são valorizadas ou depreciadas pelos sujeitos envolvidos.

O outro, para quem se dirige a Embrapa, no enfoque deste trabalho, o agricultor familiar da pecuária de leite, faz parte do programa institucional 
denominado Macroprograma 6 - Apoio ao Desenvolvimento da Agricultura Familiar e à Sustentabilidade do Meio Rural, cujas ações estão “(...) voltadas para fornecer suporte a iniciativas de desenvolvimento sustentável da agricultura familiar e de comunidades tradicionais, na perspectiva de agregação de valor (...)", bem como para aprimorar o relacionamento da Embrapa com seus públicos de interesse e com a sociedade, por meio da organização de núcleos especializados, equipes interativas ou redes, conforme sua complexidade e abrangência (EMBRAPA, 2004c:2).

A relação entre a Embrapa e a agricultura familiar, dá-se pelo conhecimento. Mas, um novo conhecimento só pode ser assimilado e acomodado num processo contínuo e de interação, e não como algo mecânico da "troca pela troca"; como observado por Arruda (2002): "Se considerarmos que a ciência não acontece dentro de uma bolha, isolada da sociedade, podemos perceber como o quadro que a cerca incidirá também sobre sua produção (...)" (ARRUDA, 2002:129).

$\mathrm{Na}$ rotina das atividades desenvolvidas pelos atores envolvidos, existe um espaço a ser preenchido quanto à qualidade da sua interação, a qual perpassa pelas suas representações. Desta forma, para balizar e fundamentar o ambiente de relação entre os sujeitos Embrapa e agricultura familiar, em que estas representações são construídas, reinventadas ou formuladas pelos atores envolvidos, precisamos deslindar uma problemática que passa pelos seguintes aspectos: as características da modernidade e sua produção material e imaterial, a partir de suas lógicas de interação; suas representações; a inovação como rede sociotécnica; suas implicações no meio rural e, ainda, a caracterização da instituição pública Embrapa, como agente do Estado; aspectos da agricultura familiar, entendida como um modo de vida da tradição e, por fim, o estudo de caso ajudará a compreender os fenômenos sociais ocorridos nos processos interativos entre a instituição pública e a agricultura familiar, no contexto da inovação tecnológica.

A presente proposta de trabalho, que busca preencher a lacuna de interpretação acerca das representações sociais (valores, sentimentos, percepções e interação) e das práticas sociais entre os produtores da pecuária bovina leiteira do segmento da agricultura familiar e a Embrapa Pecuária Sudeste, o fez numa perspectiva sociológica a partir de uma abordagem qualitativa de pesquisa. Num sentido mais abrangente, este estudo tem por objetivo geral analisar como o Estado - representante da modernidade, por meio da indução de novas práticas 
tecnológicas tem influenciado o modo de vida da tradição entendida como agricultura familiar.

Como objetivo específico, pretende-se descrever e analisar as especificidades das representações e práticas sociais, no entorno da produção e difusão de conhecimentos institucional da Embrapa Pecuária Sudeste, em contraposição ao modo de produzir da agricultura familiar da bovinocultura de leite.

Supõe-se que na construção social da imagem do outro e seu fazer, paire as possibilidades de interação mais ou menos exitosas relacionados à incorporação das inovações.

Este trabalho apresenta, no capítulo 1, algumas dimensões da modernidade a fim de lançar certa criticidade aos padrões hegemônicos do progresso, no qual o mundo rural foi açambarcado. Pretendeu-se destacar a ambiguidade da modernidade, cuja dinâmica, ao mesmo tempo em que produz benefícios e facilidades é, também, o algoz da sociedade em vista dos seus efeitos não esperados, produzindo insegurança ao promover o rompimento com uma tradição, cujas práticas conferiam certa estabilidade na produção do saber e fazer e das relações interpessoais de certos grupos.

A modernidade constroe-se como representações sociais que permeiam as interações entre os sujeitos, suas formas organizativas e institucionais de modo a modificá-las. O fazer científico e tecnológico, no âmbito do Estado, é o elemento a se destacar aqui.

Ainda, neste capítulo, se faz uma sucinta discussão acerca do modelo econômico que, historicamente, subjulgou e alijou do processo de desenvolvimento do País a agricultura familiar. Parte-se do processo de modernização da agricultura brasileira pós 1950, cujo modelo produtivista negligenciou questões relevantes como os impactos socioambientais. Traz, ainda, algum horizonte de ações mitigadoras desses efeitos, discutindo a emergência de um discurso sobre sustentabilidade.

No capítulo 2, encontra-se a caracterização de como a instituição pública de pesquisa agropecuária, Embrapa, emergiu no cenário da modernidade, como instrumento do Estado para o processo de modernização da agricultura, cuja proposta era promover o desenvolvimento do setor a partir da produção do conhecimento científico em busca da inovação tecnológica.

No capítulo 3, buscou-se apresentar as características de um dos principais sujeitos do processo de modernização da agricultura, com o qual a Embrapa 
procurou interlocução, qual seja, o agricultor familiar. A proposta é caracterizar seu modo de vida no bojo do qual se tecerão suas resistências ou simpatias aos processos inovativos, apresentados diretamente ou indiretamente pela Embrapa. A abordagem está na sua identidade, congregando suas práticas, subjetividades e produção social do seu lugar no campo.

O capítulo 4, apresenta um estudo de caso que dedicou-se a analisar em que medida o Estado, por meio da indução de novas técnicas é capaz de influenciar o modo de vida com características tradicionais, entendida como agricultura familiar. Neste contexto de interação, os sujeitos são a empresa pública de pesquisa agropecuária, Embrapa Pecuária Sudeste, e os agricultores familiares da pecuária leiteira, participantes do projeto desenvolvido por aquela instituição, cuja interação também é mediada por técnicos da extensão rural ou da cooperativa de leite. Foram estudadas e analisadas as representações da tecnologia apresentada pela instituição de pesquisa e como ela é compreendida e entendida pelos agricultores familiares da pecuária de leite.

Nas considerações finais faz-se uma reflexão acerca de como a instituição pública, produtora de conhecimento, tem que enfrentar desafios para melhorar suas interações com a produção familiar.

\section{Procedimentos metodológicos}

A metodologia utilizada neste trabalho de pesquisa, foi caracterizada como um estudo de caso e tem o caráter exploratório uma vez que visa coletar, sistematizar e analisar dados obtidos no campo para compor uma primeira configuração do problema, razão pela qual ao invés de apresentar hipóteses prévias, suscitou as mesmas e as testou ao longo de seu desenvolvimento (BECKER, 1997).

A metodologia qualitativa, proposta para o estudo de caso, utilizou procedimentos que representou a população em estudo, qual seja, a empresa pública Embrapa Pecuária Sudeste e os agricultores familiares da pecuária leiteira participantes do projeto desenvolvido por aquela instituição. A metodologia buscou, ainda, a descrição detalhada do cenário e dos sujeitos envolvidos permitindo uma melhor compreensão da natureza das interações entre estes e, na qual, a pesquisadora definiu sua amostra sobre uma base evolutiva, denominada "bola de neve" (TAYLOR e BOGDAN, 1992). 
A pesquisa bibliográfica, permitiu identificar as concepções referentes às representações sociais e suas práticas no contexto das relações interpessoais, bem como, àquelas que elucidaram questões que envolvem a construção do cenário da modernização da agricultura e a participação do Estado nesse processo. Após sua consolidação, passou-se à realização da pesquisa documental para caracterização da Embrapa, a qual buscou o discurso institucional, a partir da análise da vasta documentação sobre a história da Unidade e da Empresa. Foram analisados, como dados "objetivos", documentos históricos e públicos da unidade: Plano Diretor, relatórios de gestão, boletins, publicações e relatórios técnicos, documentos de gestão estratégica, entre outros, a fim de se obter uma perspectiva mais ampla dos cenários de modo a compreender melhor os processos organizacionais.

A seguir, foi realizada a pesquisa de campo, cujo propósito foi a obtenção das informações necessárias ao atingimento dos objetivos descritos anteriormente.

Devido à natureza da proposta de trabalho, à qual definiu dois sujeitos para análise, os quais não se sobrepõem, mas interagem na dinâmica de suas atividades; a pesquisa foi realizada em duas localidades distintas. Uma no interior da Unidade Embrapa Pecuária Sudeste e a outra nos município de Cristais Paulistas e Ribeirão Corrente, no Estado de São Paulo, com os agricultores familiares da pecuária de leite.

Para o trabalho de campo, foram realizadas entrevistas semi-estruturadas, bem como a observação direta e o uso da fotodocumentação; cuja construção da amostra atendeu ao critério de "bola de neve", já citado. Este, todavia, não define previamente o tamanho da amostra, ele é definido no momento em que as informações obtidas se repetem e nada de novo é acrescentado, denominado de saturação teórica.

\subsection{Metodologia da investigação de campo}

A metodologia adotada para este trabalho foi fundamentada em técnicas e métodos denominados de pesquisa qualitativa.

Oliveira (2005), diz que existem muitas interpretações a respeito da expressão pesquisa qualitativa e diante de tantos significados, ela a conceitua “(...) como sendo um processo de reflexão e análise da realidade através da utilização de 
métodos e técnicas para compreensão detalhada do objeto de estudo em seu contexto histórico e/ou segundo sua estruturação" (OLIVEIRA, 2005:41).

De acordo com a mesma autora, na abordagem qualitativa, é importante considerar todos os fatos e fenômenos, pois tem como fonte direta de dados o ambiente natural. Cita, ainda, seu caráter descritivo, o significado que as pessoas dão às coisas e a sua vida (a subjetividade) e a análise dos dados tende a seguir um enfoque indutivo.

Neste trabalho, a pesquisa foi baseada no estudo de caso, que constitui uma das técnicas da abordagem qualitativa. $O$ mesmo permite chegar a uma compreensão abrangente do fenômeno de estudo, ou seja, quem são seus membros? Quais suas modalidades de atividade e interação recorrentes e estáveis? Como essas atividades se relacionam umas com as outras e como o grupo está relacionado com o ambiente que o circunda. Ao mesmo tempo, o estudo de caso permite também desenvolver declarações teóricas mais gerais sobre a freqüência do processo dentro do fenômeno estudado (BECKER, 1997).

Segundo Becker (1997), por objetivar compreender todo o comportamento do grupo, o estudo de caso não pode ser concebido para testar proposições gerais. Em contraste com o experimento de laboratório, o qual testa uma ou poucas proposições intimamente relacionadas tão rigorosa e precisa quanto possíveis; o estudo de caso tem que ser preparado para lidar com uma grande variedade de problemas teóricos e descritivos.

$\mathrm{Na}$ estruturação da pesquisa, que tem como foco as interações sociais em torno da pecuária bovina de leite, foram formados três grupos de amostras: a) a Embrapa Pecuária Sudeste; b) agricultores familiares da pecuária bovina de leite, pertencentes ao projeto da agricultura familiar da Embrapa Pecuária Sudeste e c) como grupo de controle, agricultores familiares da pecuária bovina de leite, pertencentes ao segmento da agricultura familiar denominados "grupo sem interação" com a Embrapa Pecuária Sudeste. A divisão representa os diferentes recortes dos clientes acessados ou não pela Embrapa Pecuária Sudeste e, por conseguinte, permite analisar se interações diretas com a referida instituição pública, podem influenciar mais decisivamente a adoção de processos inovativos.

Para o desenvolvimento das atividades de campo, foi realizado contato prévio com alguns sujeitos dos grupos focalizados a fim de construir a amostra. 
Os instrumentos utilizados na coleta de dados de campo foram as entrevistas semi-estruturadas, a observação direta, relatos orais, diário de campo e a fotodocumentação.

Para a realização das entrevistas, seguiu-se um roteiro, no qual constaram tópicos pré-definidos com base no que o estado da arte suscitava e não obedeceu um rigor de seqüência, mas pautou-se pelas narrativas que os próprios entrevistados sentiram-se melhor na busca de apresentar os seus fazeres e dos significados a eles atribuídos (ANEXOS I e II).

A condução da entrevista semi-estruturada, foi feita de acordo com a metodologia proposta por Taylor e Bogdan (1992), na qual, por meio do trabalho de campo, buscou-se, inicialmente, a interação social com os entrevistados, cujo objetivo era estabelecer uma relação de confiança, integração e aceitação da figura do pesquisador. Em seguida, passou-se à obtenção dos dados de campo.

A entrevista semi-estruturada requer um desenho flexível da investigação, ou seja, nenhum número ou tipo de informante foi especificado. Neste trabalho, os informantes não têm seus nomes revelados, eles são identificados por letras; estas, por sua vez, foram distribuídas aleatoriamente e não atendeu a ordem da entrevista, cujo propósito foi garantir-lhes que as características gerais do grupo, e não dos indivíduos, era o que se buscava, com o explicitado pelo entrevistador.

Sua obtenção, seguiu um estilo de conversação livre e não de um intercâmbio formal de perguntas e respostas; ela foi dinâmica e flexível. Para auxiliar a atividade, lançou-se mão de um gravador, o qual ajudou a elucidar os lapsos de memória da pesquisadora. Taylor e Bogdan (1992) fazem ponderações sobre o uso do gravador, consideram que o aparelho pode causar incômodo ou inibir os entrevistados. Contudo, não o condena, pois acreditam que o pesquisador, ao assegurar o entrevistado, de que se trata de uma investigação científica ele, provavelmente, ficará mais relaxado.

No caso particular deste trabalho, não houve, por parte de nenhum dos grupos entrevistados, especialmente dos agricultores familiares, desaprovação pelo uso do gravador.

Após cada entrevista, foi redigido o diário de campo, o qual permitiu melhor compreensão das informações obtidas e de modo a não se perder nenhum registro importante, sobretudo aquele derivado da observação direta das práticas dos informantes e das demais linguagens, gestuais e corporais, e aspectos do ambiente. 
A fotodocumentação, no contexto do estudo de caso, tem um papel revelador das questões que estão subjacentes à explanação objetiva da fala do entrevistado. Revela aspectos não mencionados ou que não se quis apresentar, ou ainda pode corroborar ou negar o que foi dito, permitindo, na contraposição das informações, obtermos a análise crítica mais apurada acerca do fenômeno investigado.

Para a construção da amostra, tanto da Embrapa quanto dos pecuaristas, foi levado em conta o critério de "bola de neve", em que se inicia com um entrevistado denominado "guia" ou "piloto", o qual, por sua vez, indica o próximo a ser entrevistado, e assim por diante, até as respostas começarem a coincidir ou nenhum outro elemento novo seja adicionado. Neste procedimento, não foi adotado a aleatoriedade na seleção de depoimentos a fim de propiciar a comparação e estabelecer as correlações significativas entre as representações sociais (TRIPOLDI et al,1981).

No ambiente interno da Embrapa Pecuária Sudeste, o guia foi representado pela chefia de Pesquisa e Desenvolvimento (P\&D), que recomendou o próximo empregado, e este, por sua vez, indicou o seguinte e assim, sucessivamente, até o limite ou nível de saturação teórica. Por ora, para efeito desse trabalho, todos os empregados entrevistados serão denominados "técnicos", pois estamos falando do saber perito que representa a instituição pública num processo empírico.

No caso dos agricultores familiares, devido ao fato do projeto Agricultura Familiar, desenvolvido na Unidade e intitulado "Transferência de tecnologia e conhecimentos para produtores familiares de leite, por meio da capacitação de extensionistas ${ }^{1}$ rurais, no Estado de São Paulo", hoje denominado "Balde Cheio" - e será por este nome que, neste trabalho, a partir de agora, irei me reportar - estar presente em 102 municípios do Estado de São Paulo, por meio da ação de transferência a partir dos técnicos extensionistas da Coordenadoria de Assistência Técnica Integral - CATI, entre outros, como da Secretaria Municipal de Agricultura e cooperativas, houve a necessidade de definir uma estratégia de acesso a estes produtores. Sendo assim, elegeu-se alguns critérios para definição do município para desenvolver o trabalho.

\footnotetext{
${ }^{1}$ Embora o foco esteja na capacitação dos extensionistas, mais que isso, a instituição enseja modificar a realidade concreta das práticas elaboradas pela agricultura familiar, o que não elimina a interação direta por meio das unidades demonstrativas denominadas "sala de aula", entre outros, e é nesse aspecto que o trabalho pretende focalizar.
} 
Inicialmente, contactou-se as regionais da CATI, parceiras no projeto, para que as mesmas fornecessem informações quanto aos números de agricultores familiares, produtores de leite, participantes do programa e dos não participantes (os últimos como grupo de controle). Dos 17 Escritório de Desenvolvimento Regional (EDR) da referida coordenadoria, que foram consultados, apenas sete repassaram as informações. Para a escolha da regional, buscou-se parâmetros de similaridades entre os municípios tais como: acesso a mercado, infra-estrutura de estrada e transporte, mais tempo no projeto e maior número de técnicos da CATI.

Os critérios adotados para definir, inicialmente, o município, foram: maior tempo de participação no projeto, maior número de produtores participantes do projeto e presença do técnico da CATI. Entretanto, dada à natureza da metodologia, o local da pesquisa não, necessariamente, ocorreria em um único município ou regional, pois o produtor poderia indicar um outro que não estivesse naquele município ou regional, fato este ocorrido. Desta forma, os municípios nos quais a pesquisa de campo foi realizada foram Cristais Paulistas e Ribeirão Corrente, ambos do Regional de Franca-SP. A partir daí, o "guia ou piloto" foi o produtor do município de Cristais Paulista, cuja propriedade é vista, dentro do projeto, como "sala de aula", e as demais são denominadas propriedades assistidas.

Neste caso, a evolução da amostra também se deu dentro do critério de "bola de neve".

Para o "grupo sem interação", ou seja, os produtores não participantes do projeto de Agricultura Familiar, residentes na mesma região, e que não acessaram/adotaram o conjunto da tecnologia agrupada pela Embrapa Pecuária Sudeste, buscou-se identificar, pontuar e caracterizar o não acesso/adoção dessas tecnologias pelos mesmos, e sob quais circunstâncias ficaram alijados do processo.

Contudo, vale salientar, que foi observado durante as entrevistas um entrosamento, ainda que discreto, entre os grupos "com interação" e "sem interação", embora não intermediado pelo técnico da extensão nem pela Embrapa, mas que pode levar à adoção da tecnologia por aqueles não pertencentes ao projeto, ou seja, pode não haver interação com a instituição pública, mas pode existir a comunicação entre os produtores, resultando numa adoção da tecnologia pela via da informalidade ao projeto.

O critério adotado para a obtenção da amostra deste grupo, também foi o de "bola de neve"; cujo "guia ou piloto" foi o produtor pecuarista, que, pela circunstância 
de acesso e logística, melhor atendeu à atividade. Tal "grupo sem interação" serve ao propósito de ser entendido como um "grupo de controle" que pontua a qualidade das interações e impacto que a Embrapa exerce sobre os demais.

Ao final das entrevistas, o tamanho da amostra ficou assim definido por grupo: a) Embrapa Pecuária Sudeste (nove); b) produtores da pecuária bovina de leite, pertencentes ao projeto da agricultura familiar da Pecuária Sudeste (seis) e c) produtores da pecuária bovina de leite, pertencentes ao segmento da agricultura familiar denominados "grupo sem interação" (sete).

A relativa similaridade do conteúdo das entrevistas, em conjunto com as imagens das fotos, nesta abordagem qualitativa, torna possível considerar a amostragem suficiente e representativa nos contatos realizados, fazendo com que elas produzissem, em seu conjunto, informações consistentes para o estudo.

Apresentamos, ainda, um sujeito muito importante na interação ocorrida entre os grupos acima definidos, qual seja, os "técnicos da extensão rural" e técnicos da cooperativa de leite. Estes, embora sejam partícipes ativos na dinâmica desta relação; contudo, não iremos considerá-los um grupo de amostra e sim um elemento da rede sociotécnica, esta, por sua vez, segundo Latour (2000), é importante não apenas para dar suporte aos discursos institucionais, mas também para reforçar como verdade e necessidade, o objeto proposto. Assim, suas contribuições, somarão às análises e interpretações da ação do Estado no tema das inovações. 
A figura 1 apresenta o quadro esquemático das interações entre os atores envolvidos e permite uma melhor compreensão da dinâmica e qualidade desta interação:

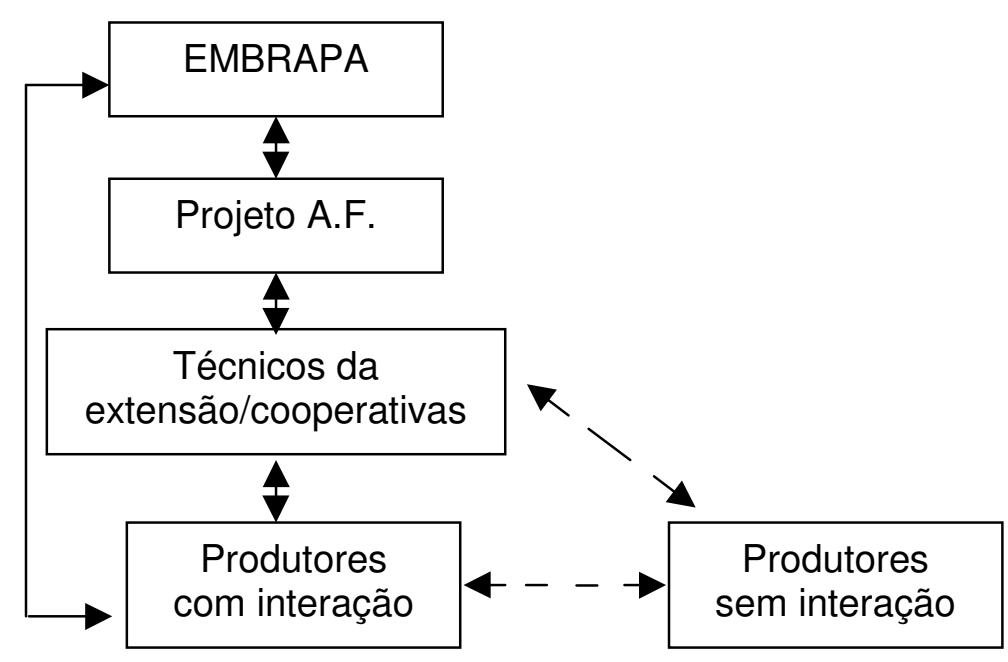

Figura 1: quadro esquemático dos atores envolvidos na análise.

$\longrightarrow$ relação/interação no âmbito do projeto

$\leftarrow$ - $\rightarrow$ relação/interação fora do âmbito do projeto

Vale salientar que os dois sub-grupos, descritos acima, não representam a totalidade do universo das interações ocorridas nas relações da instituição Embrapa com o pecuarista da produção familiar. Relações antes existentes, podem não mais acontecer; há níveis de intensidade de relacionamento diferenciado no seu conteúdo e no tempo. 


\title{
CAPÍTULO 1
}

\section{CARACTERÍSTICAS DA MODERNIDADE}

Nas sociedades tradicionais as relações de produção, de trabalho e de afetividade se davam a partir do local de convivência e de identidade, conforme observado por Giddens (1991):

\begin{abstract}
"A história "começa" com culturas pequenas, isoladas, de caçadores e coletores, se movimenta através do desenvolvimento de comunidades agrícolas e pastoris e daí para a formação de estados agrários, culminando na emergência de sociedades modernas no Ocidente" (GIDDENS, 1991:15).
\end{abstract}

Berman (1996) propõe, para que se possa falar de características próprias à modernidade, que esses 500 anos do período moderno sejam subdivididos em três fases principais. A primeira fase diz respeito ao surgimento de algumas dessas transformações que deram origem a modernidade. O período compreendido do início do século XVI até o fim do século XVIII, é uma modernidade em estágio embrionário, uma modernidade que ainda não se reconhece modernidade.

A segunda fase teria início no período próximo à Revolução Francesa, quando pode-se dizer, segundo o autor, que pela primeira vez um grande e moderno público partilha o sentimento de viver uma mesma experiência - viver em uma era revolucionária. Esse homem moderno ainda não o é inteiramente porque tem o coração dividido. Ainda sabe bem o que era viver num mundo não-moderno. É um homem que vive em dois mundos a um só tempo.

A terceira fase surgiria com o século $X X$, com a expansão do processo de modernização que chega a abarcar virtualmente todo o mundo. Esse "compartilhar" uma experiência, vivência e sentimentos comuns chega aqui a seu ápice em termos de extensão do movimento.

O autor estabelece uma diferença entre a experiência moderna dos séculos XIX e XX. O século XIX ainda vive aquele homem moderno dividido, ambíguo, que não se enxerga exatamente moderno e ao mesmo tempo já o é. No século $X X$, o processo de modernização se expande por todo o mundo, criando uma cultura 
mundial do modernismo. Acentua ainda, o aspecto fragmentador que isto gera e este fenômeno da fragmentação, que distancia o indivíduo de alguns aspectos da sua identidade, se acomoda bem nas diferentes "modernidades" e nas diferentes apropriações do pensamento, valores e práticas modernos.

Santos (1992) aborda aspectos dessa fragmentação quando fala sobre a expansão do capital técnico-científico que leva a deslocamentos de áreas tradicionais para outras áreas, na produção dos fixos e fluxos, cujas consequências são quebras de vínculos e de referências tão comuns nas sociedades tradicionais e que, neste caso, ele vai chamar de "desculturização".

"(...) consequência importante, isto é, à tendência à "desculturização" da área, na medida em que a substituição das pessoas, a alteração dos equilíbrios sociais de poder, a introdução de novas formas de fazer, geram desequilíbrios dos quais resultam, de um lado, a migração das lideranças locais tradicionais e a quebra de hábitos e tradições, e, de outro lado, a mudança de formas de relacionamento produzidas lentamente durante largo tempo e que se vêem, de chofre, substituídas por novas formas de relações cuja raiz é estranha e cuja adaptação ao lugar tem um fundamento puramente mercantil" (SANTOS, 1992:46).

Para Giddens (1991), estas relações tomam novas características e conformidades inimagináveis, com implicações socioambientais deletérias:

\footnotetext{
“(...) o trabalho industrial moderno tinha consequências degradantes, submetendo muito seres humanos à disciplina de um labor maçante, repetitivo. Mas não se chegou a prever que o desenvolvimento das "forças de produção" teria um potencial destrutivo de larga escala em relação ao meio ambiente material” (GIDDENS, 1991:17).
}

Vale ressaltar o efeito poupador, quando não, destruidor do próprio trabalho causado pela modernidade, numa lógica perversa e autodestrutiva, a qual ocorre nas mais diferentes áreas de geração de emprego, seja no ambiente urbano seja no meio rural. Como exemplo, pode ser citado o processo de modernização ocorrido na agricultura, cuja introdução de novas tecnologias produziu resultados para mão-de- 
obra do campo que levou à insegurança, sazonalidade e instabilidade do emprego (SILVA, 1981).

Silva (1981:112) afirma que a simples mudança na base técnica de produção, como, por exemplo, a substituição das culturas "tradicionais" ou "em transição" por modernas ou simplesmente a aquisição de um equipamento como a colhedeira, pode "(...) acentuar ainda mais a sazonalidade da ocupação da mão-de-obra na agricultura (...)". O autor, afirma ainda que: "É importante insistir que existe uma estreita vinculação entre relação de trabalho e o nível de tecnologia utilizado nas propriedades agrícolas" (SILVA,1981:113).

A ameaça e os níveis de risco produzidos pela modernidade têm extensões das mais diversas, porém, nada pode ser mais devastador e preocupante que aqueles exercidos sobre meio ambiente natural, o qual viabiliza a condição da existência humana. Este é um fenômeno novo, o qual ainda não sabemos lidar muito bem.

Os sistemas produtivos têm exaurido a matéria prima que retiram da natureza, cujo valor de uso é de altíssima qualidade. Contudo, devolvem ao meio ambiente resíduos contaminantes ou poluentes. Como se não bastasse, a velocidade em que ocorre o consumo dos produtos, bem como a geração de novas demandas, exigem da natureza uma recuperação numa urgência tal que a mesma não é capaz de produzir.

Neste contexto ainda, para garantir o abastecimento do mercado consumidor, também é necessário a busca por novas fontes de energia para suprir as demandas produtivas cada vez mais vultosas.

Os efeitos desses desequilíbrios são observados nos mais diversos desastres ambientais como o aquecimento global, enchentes, terremotos, desordem no comportamento dos animais, instabilidade climática e perda da biodiversidade.

Ainda que toda benesse produzida pela modernidade se traduza, efetivamente, em aumento de bem estar para certos segmentos da sociedade, esta não a garante para amplos contingentes humanos e seguridade para todos. Ademais, se as interações sociais se intensificam em condições de modernidade, a qualidade das mesmas também se fragiliza.

"A modernidade, pode-se dizer, rompe o referencial protetor da pequena comunidade e da tradição, substituindo-as por 
organizações muito maiores e impessoais. O indivíduo se sente privado e só num mundo em que lhe falta o apoio psicológico e o sentido de segurança oferecidos em ambientes mais tradicionais" (GIDDENS, 2001:38).

Nas sociedades tradicionais, a estrutura de poder encontrava-se, normalmente, nas mãos de grupos que definiam, pelo controle territorial, as conformações materiais e simbólicas do lugar. Na sociedade da modernidade, este poder passa a ser do Estado, um estado laico.

Desta forma, para pensar a modernidade é importante apresentá-la a partir das principais variáveis que a compõe, ou seja, pelas suas estruturas como instituições e formas de organizações e pelas suas dinâmicas sociais, quais sejam: como os sujeitos interagem nessas instituições ou entre as instituições e ainda com suas formas de organização. Ela é, ao mesmo tempo, estável como organização, como norma, rotinas e procedimentos; e é movente também, enquanto dinâmica porque os indivíduos estão sempre em interação, exercendo suas funções e papéis na sociedade. Portanto, é importante compreender a modernidade por esses elementos materiais, de interações e de produção simbólica, os quais estão contidos tanto nas estruturas da sociedade moderna quanto nas suas dinâmicas. Sem estrutura e dinâmica juntas, acopladas, as duas não têm sentido. Estrutura sem dinâmica não há razão de ser; e dinâmica sem estrutura é o caos.

Ainda como estrutura e dinâmica, a modernidade possui aspectos ligados à objetividade e à subjetividade, ou seja, questões materiais e imateriais que estão presentes em ambas. Fenômenos que precisam ser reafirmados no cotidiano das pessoas através dos seus significados a fim de que se estabeleçam como verdade e necessidade.

As novas estruturas que surgem na modernidade, sobretudo nos séculos $X X$ $X X I$, serão aquelas que pretendem dar uma dinamicidade distinta aos modos de vida do campo o que, no seio do Estado, irrompe novas complexidades de órgãos e funções diversas e complementares voltados para a agropecuária.

Como dinâmica, é necessário que os produtores rurais possam interagir com essas regras, procedimentos, normas, enfim e exerçam o papel definido pela modernidade. 
Neste contexto, surge a Embrapa, bem como a Embrapa Pecuária Sudeste, unidade descentralizada daquela, constituindo infra-estrutura física e de pessoal, voltadas para a geração de novas tecnologias, novas práticas e novos instrumentos.

Ao orientar-se para a transferência de tecnologia à sociedade, pressupõe-se, que a interação desse órgão do Estado com o produtor, só atinge seu desiderato se o produtor aderir à modernidade.

Esse pressuposto, permite uma reflexão sobre o que significa para o produtor aderir tais inovações tecnológicas ou adequar-se a determinados procedimentos. É bem verdade, que esta adesão não se dá na sua totalidade, pois o produtor tende a adaptar suas práticas, frente a um conjunto de pressões, de modo a limitar os efeitos do risco. Isto se constitui em uma estratégia de sobrevivência (BONNAL et al, 1994).

Mais que uma oportunidade, inserir-se no processo de mudança tecnológica, representa uma imposição do mercado capitalista e modernizado. É possível que a adoção de novas práticas, também se traduza em uma oportunidade, mas é preciso atentar para os aspectos mais gerais, os quais, na maioria das vezes, significa limitar o produtor a sua condição de sê-lo por meio de suas próprias práticas, quando não, pode eliminá-lo da atividade; numa tentativa de torná-lo um empresário (SILVA, 1981).

Além das questões práticas e objetivas, aspectos da sua identidade, modo de ser e fazer, as quais, de certo modo, sofrem alterações; quando, por exemplo, no processo de ordenha, Ihe seja exigido pela legislação, um novo traje que, além de não fazer parte do seu vestuário habitual, na sua compreensão, não condiz com a atividade desempenhada.

“(..) a gente não entende o seguinte: como que você chega aqui de branco e vai trabalhar no meio de vaca tirar leite, bota branca, roupa branca, não existe isso. A inspeção federal chegar aí, pegar o funcionário ou a gente sem fazer barba, tem que tomar banho antes de tirar o leite, é o fim do mundo, não existe! Fora da realidade". (agricultor familiar B).

Ainda, partindo do exemplo acima, no caso da ordenha manual, tem um significado para o produtor que vai além da sua prática em si. Significa, um fazer, o qual, Ihe confere habilidades que não é qualquer um que consegue desempenhá-la 
e ele se exibe com orgulho. A habilidade das mãos ao manejar o úbere da vaca, de modo a fazer jorrar o líquido branco e na temperatura ideal para ser saboreado, Ihe foi herdado e apreendido na sua rotina; sem contar a postura corporal a qual poucos conseguiriam manter-se por muito tempo (Foto 1).

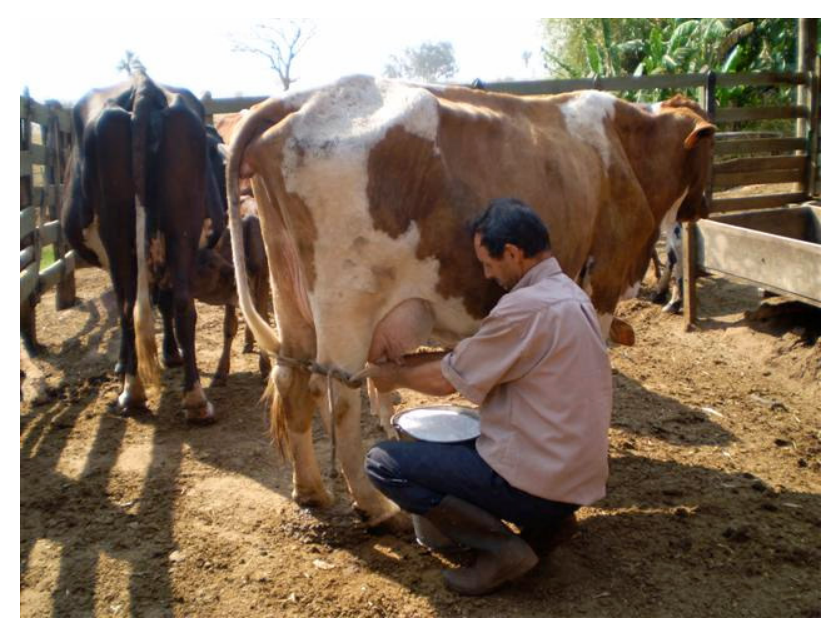

FOTO 1: produtor em sua rotina de trabalho. A postura de cócoras ao realizar a ordenha manual.

É óbvio que a ordenha mecânica, uma recomendação perita, lhe confere menor esforço físico e ganho de tempo, mas não é totalmente verdade que the confere qualidade e segurança do produto quando da entrega para seu processamento. Ademais, pode ser fator de discriminação e exclusão, conforme observação a seguir:

“(...) o processo de modernização do setor leiteiro no Brasil ainda não mostrou resultados em termos de melhoria da matéria-prima recebida nas plataformas dos laticínios. No entanto, a 'granelização' do leite tem como uma de suas consequências a seleção de produtores, o que está implícito no processo. Sendo assim, a refrigeração e a granelização representaram a médio prazo um forte impacto sobre o produtor não especializado de leite" (SALMAN, 2007:1).

Outro aspecto importante, está relacionado às suas formas de relações interpessoais. Estas, muitas vezes, estão arraigadas e mantidas por laços de parentesco, amizade e compadrio e que atendem, numa condição de necessidade pela fase da produção, a ajuda mútua e solidariedade. 
"Igual às vezes no [vizinho], de vez em quando a gente vai lá, a gente vê, mesmo lá pra reformar piquete eu já ajudei lá".

(agricultor familiar $\mathrm{G}$ )

É porque aqui em casa a gente bem dizer é só família, igual você chegou falando naquela hora lá, a gente usa pouco serviço de fora, então por isso que demora. Às vezes a gente chama o pai dela, meu sogro pra ajudar, gente de fora é pouca coisa".

(agricultor familiar D)

No processo de modernização, dada as novas exigências de produtividade e mercado, são exigidas novas formas de relacionamento, como a organização dos produtores, especialmente para a venda do seu produto e compra de insumos. Contudo, esta é uma proposta que fragiliza as relações estabelecidas, uma vez que envolve práticas de negociações, com as quais os produtores não estão acostumados, gerando desconfiança:

"No ano passado, a gente comprou farelo de soja, num grupo... Aí os que entraram comigo, pra comprar comigo, o farelo de soja, reclamaram; então, não tem jeito de trabalhar em grupo...".

(agricultor familiar E)

O incentivo à venda coletiva, bem como de outras práticas, na maioria das vezes, parte de grupos de fora e a presença desses grupos distintos no seu espaço de convivência e familiaridade, pode gerar tensões e conflitos que venham desestabilizar o sentimento de estar num lugar, antes, de interconhecimento, no qual foi construída sua história social (Wanderley, 2000).

Assim, a adoção de novas práticas e procedimentos, pode levar o produtor a novos ajustamentos ao exercício da sua atividade. O que nos leva a crer que, não é o fato dos agricultores não estarem abertos à incorporação de novas técnicas e práticas, mas que, talvez, para aceitá-las, deva existir um equilíbrio entre as novas propostas e seus saberes.

O item a seguir elucida alguns dos aspectos da construção material dos processos de reprodução social. 


\subsection{A modernidade como produção material da existência social}

A modernidade consiste em expressões material e imaterial.

A modernidade se expressa como um processo histórico, significa dizer que ela é uma construção social, ou seja, não é algo dado, mas é feita pela sociedade e, como tal, tem que ser reafirmada constantemente pelos indivíduos, pelos grupos, pela sociedade em geral. Assim, é um pouco concreta e um pouco simbólica, vivida pelos sujeitos que interagem na produção de um determinado lugar e em relação ao que é experimentado nas suas dimensões material e imaterial.

A modernidade é em parte uma lógica, em parte objeto, em parte escolhas pessoais e de grupos, em parte interações e, assim, ela é um pouco concreta e um pouco simbólica.

Giddens (1991) analisa a modernidade enquanto descontinuidade entre as ordens sociais tradicionais e as instituições sociais modernas. Quais seriam, então, para ele, as características desta descontinuidade? Primeira, o ritmo de mudança que a modernidade põe em movimento, o qual em civilizações tradicionais seria inimaginável. Segunda, o escopo da mudança, isto é, a abrangência global desta e terceira a natureza das instituições modernas (o sistema político do Estado, a dependência por grande produção de fontes de energia, a transformação em mercadoria de produtos e trabalho assalariado). Uma das coisas assinaladas pelo autor, ainda, é que a modernidade se caracteriza por dissolver as instituições arcaicas, tradicionais ou, também, o valor que elas tinham; como a igreja, o valor da família agregada, nuclear, que reside e vive no mesmo lugar.

Em termos materiais, a modernidade se expressa no aumento dos fluxos e escalas de produção de mercadoria, aumento dos fluxos de transações comerciais, valorização das competências peritas, capacitadas pelas instituições técnicas (GIDDENS, 1991).

Assim, a modernidade propõe transformar o que era considerado arcaico em algo "moderno".

"Seu aspecto mais óbvio é a expansão da divisão global do trabalho, que incluiu as diferenciações entre as áreas mais e menos industrializadas no mundo. A indústria moderna se baseia intrinsecamente em divisões de trabalho, não apenas ao que diz respeito às tarefas mas também à especialização regional em termos 
de tipo de indústria, capacitações e a produção de matérias-primas" (GIDDENS, 1991:80).

A modernidade também confere à sociedade uma burocracia regida por critérios da impessoalidade, da necessidade da produção de regras, de planejamento. É este arcabouço que permite às instituições modernas aumentar sua dinâmica, previsibilidade, controle e assim tornar-se mensuradora do desempenho e controle racional (WEBER, 1981).

A produção social do lugar é uma produção de fixos e fluxos de instituições e pessoas. Os fluxos viabilizam a instalação de novos fixos. Nesta dinâmica, as instituições e corporações se organizam dentro da racionalidade burocrática, descrita por Weber (1981), para produzir mercadorias que vão desde bens de capitais como máquinas, infra-estrutura, rodovias, eletricidade, siderurgia, enfim; bens que modificam o território, sua base biofísica que geram novos fixos e novos fluxos no território; bem como produzem sua dinâmica. Assim, a sociedade é algo que não existe fora do território e sim por suas relações com ele.

Para Santos (2002), essas relações são profundas e complexas e que sofrem grandes ingerências do Estado e corporações.

\footnotetext{
"Base da vida material que transcende a nação mas cujo uso, em última instância, é regulado pelo Estado, o território é hoje marcado pelo fato de que não há mais espaços vazios, sendo todo ele ocupado por dados atuais - do mundo já concreto ou do mundo das intenções" (SANTOS, 2002:21).
}

Para Santos (1992:14), a produção do lugar se dá por suas atividades econômicas, bem como pelos "diversos elementos do espaço que estão em relação uns com os outros: homens e firmas, homens e instituições, firmas e instituições, homens e infraestruturas etc.”. Porém, o autor considera que estas interações "(...) não são relações apenas bilaterais, uma a uma, mas relações generalizadas" (Id.: 14). Para ele, a produção do lugar é uma produção de fixos e fluxos, ritmos da modernidade que são diferentes da tradição, ou seja: "(...) os lugares - e os homens com eles - mudam muito rapidamente e muito brutalmente de significação" (SANTOS, 2002:22). 
Segundo Tavares (1983), a produção deste lugar se dá também pela influência e interveniência de um Estado planificador, que investe em alguns setores estratégicos e dá forma e tratamento aos fixos e fluxos produzidos; dando uma feição industrial para um país que até então tinha uma economia de base agrícola.

Com o crescimento populacional, o desenvolvimento da agricultura, a criação das cidades e o aumento da divisão de trabalho, no contexto brasileiro, ocorreram mudanças nos territórios quanto aos aspectos e conceitos sobre o lugar e a localização.

Santos (2002:22), considera que as idéias de "lugar" e de "localização", antes vistas como análogas, hoje estão cada vez mais distintas. Para ele, enquanto uma dada fração do lugar permanece inalterada, marcada pelas mesmas características geográficas e mantendo o mesmo nome herdado, a "localização" muda constantemente, ou seja, é o seu lugar econômico, social e político, cujos aspectos são dinâmicos e produzidos pelas interações entre os indivíduos e as instituições modernas, os quais levam às distinções entre o "lugar" e a "localização".

Contudo, no caso brasileiro, segundo o autor, o tratamento dado na organização político-territorial ainda é feita como se existisse a unidade entre ambos: "Mas a organização político-territorial ainda é pensada como se houvesse unidade entre lugar e localização e como se os meios materiais e jurídicos para enfrentar a nova síntese histórica pudessem ser os mesmos" (SANTOS, 2002:23).

Alguns aspectos desse contexto teórico, podem ser observados no cenário da agricultura brasileira; pois esta, nas últimas décadas, passou por grandes mudanças estruturais. A reestruturação do setor, com forte intervenção do Estado, que teve início a partir dos anos 50 e se intensificou na década de 70, foi baseada num pacote tecnológico que abarcava itens distintos, porém, complementares, para o conjunto das atividades agropecuárias (NEAD Estudos, 2007).

Tal conjuntura, produziu uma nova configuração do território brasileiro, especialmente, do espaço rural, o qual envolve não somente seus aspectos físicos, no que tange à sua paisagem, como a abertura de novas rodovias, alteração nos centros de consumo e de produção e instalações de firmas e equipamentos; mas também, no que se refere às políticas agrícolas - inclusive àquelas voltadas para a produção de novas fontes de energia e das relações de trabalho no campo. 
"A partir daí, a paisagem rural mudou radicalmente. Milhares de máquinas, tratores e insumos agrícolas substituíram paulatinamente a maneira de produzir até então existente (...) cujo resultado foi a chamada industrialização do campo, com a presença de grandes empresas nacionais e internacionais e a concentração acelerada da terra e da renda" (SILVA, 2004b:21).

As propriedades rurais passaram a integrar-se às agroindústrias, o que levou ao aumento de sua dependência em relação aos insumos industriais. Além disso, passam a produzir bens de consumo final, bens intermediários ou matérias-primas para outras indústrias de transformação. Nesse sentido, o produtor já não possui mais a autonomia sobre sua produção.

\footnotetext{
"A integração com a indústria não apenas determinou mudanças nos cultivos das grandes propriedades e na utilização da mão-de-obra assalariada, como atingiu também a agricultura familiar. A decisão sobre o que produzir e como produzir passou a ser determinada pela cadeia produtiva e não mais pelo agricultor (...)" (NEAD, 2007:7).
}

Silva (1981:117) salienta que a pequena propriedade persiste, mas não se constitui à mesma: "Nas regiões próximas aos grandes centros urbanos a pequena propriedade foi transformada pelo capital numa exploração intensiva: ela é ainda pequena em termos de área, mas é grande quanto ao valor ou a magnitude da produção (...)". Um exemplo disso, é a criação de aves e suínos - mais precisamente na região Sul, pelas propriedades familiares; para o fornecimento às indústrias alimentícias como a Sadia e a Perdigão. Na região Sudeste, destaca-se as indústrias de laticínios, como consumidoras do produto leite, produzido pelas pequenas propriedades (GUILHOTO, J. J. M., AZZONI, C. R. et al., 2007).

O desenvolvimento tecnológico, transformou, por exemplo, o Cerrado brasileiro; considerado uma região marginal para a agricultura, pois sua economia era baseada na criação extensiva de gado, extração de madeira, entre outras; em uma das regiões brasileiras com maior taxa de crescimento agrícola. Hoje ele representa $58 \%$ da produção nacional de soja, cuja região tradicionalmente produtora dessa leguminosa era o Sul do País (EMBRAPA, 2006b). 
A política de modernização da agricultura, que visava o aumento da produção e da produtividade, com vistas à produção de alimento barato e em grandes quantidades, transformou não apenas o Cerrado, mas várias outras "regiões substituíram culturas tradicionais por outras com maior rendimento econômico e voltadas à exportação" (NEAD Estudos, 2007:9).

Em tempos atuais, nada tem sido mais expressivo no que se refere a mudanças na paisagem, quanto o fenômeno "cana-de-açúcar". Com o advento dos biocombustíveis, como alternativa à fonte de energia renovável, para o abastecimento dos mercados interno e externo, cuja demanda tem sido cada vez mais crescente, as áreas de plantio de cana se expandiram para além das fronteiras existentes e atingiram regiões não tradicionais para este produto. Em São Paulo, por exemplo, ela já atingiu o município de Araçatuba, uma área historicamente voltada para a pecuária. Sua expansão, também chegou ao Triângulo Mineiro e nos estados de Goiás, Mato Grosso e Mato Grosso do Sul (OLIVEIRA \& VASCONCELOS, 2006).

A perspectiva, ainda, é da inauguração de novas usinas; hoje elas giram em torno de 300 unidades (OLIVEIRA \& VASCONCELOS, 2006).

Esse quadro geral, pôde, entretanto, ser observado, também, de forma mais particularizada, na região na qual o trabalho de campo, deste estudo, foi realizado. Nas pequenas propriedades visitadas, a maioria delas faz parte de algum projeto de arrendamento para o plantio da cana, ofertado pelas usinas ou mesmo cooperativa de leite: "Inclusive agora que a gente arrendou pra cana, então a gente começou a encurtar a área um pouquinho (...)" (Agricultor familiar B).

Alguns produtores que ainda não aderiram ao arrendamento de área para o plantio da cana, estão na espera da oportunidade. Embora eles tenham afirmado não ser a cana uma ameaça à produção pecuária de leite, o entorno das suas respectivas propriedades, já não contam mais com muitos produtores de leite. Segundo eles, muitos abandonaram a atividade e venderam suas propriedades, foram para a cidade e outros alugam como entretenimento:

"Vixe! Bom, tinha mais né? De uns 4/5 anos pra cá parou bastante, foram pra cidade, quase todos, mudou mesmo... Muita gente vendeu pra fábrica de sapato, venderam tudo as propriedades pra lazer de final de semana, é um sítio pequeno, vendeu pra eles, fizeram tipo 
uma chácara, refúgio de final de semana, põe uma vaquinha branca nelore lá...".

(agricultor familiar D)

"Porque, por aqui, não tem tirador de leite mais, você não acha... Saiu do leite, a maior parte arrendou pra cana, a cana que vai estragar tudo pra nós".

(agricultor familiar $\mathrm{G}$ )

As transformações estruturais que ocorrem na agropecuária brasileira estão intimamente ligados ao desenvolvimento científico e tecnológico voltados para o setor. Entre as instituições promotoras deste desenvolvimento, configuram a Embrapa, universidades e iniciativa privada (OLIVEIRA \& VASCONCELOS, 2006).

Aspectos simbólicos também se fazem presentes nas dinâmicas da interação entre os grupos sociais consubstanciados em ambientes da modernidade. Assunto a ser abordado a seguir.

\subsection{A modernidade como produção simbólica da existência social}

Quando a sociedade se moderniza e cria as instituições sociais, as mesmas forçam a dissolução de hábitos para entrar em novos enquadramentos ditos burocráticos. O mundo da moda, assim como o que gera uma diversidade de hábitos alimentares e até tratamentos médicos e opções farmacêuticas passam por essa racionalidade e, ao mesmo tempo, geram violências simbólicas e desqualificam 0 mundo do outro.

A organização burocrática, como as frações do Estado, a partir dos seus regulamentos, normas e regras, moldam o comportamento dos grupos aos quais está dirigido, gerando procedimentos e práticas, os quais, ao mesmo tempo em que são produções material, também são produções simbólica, que pretendem instituir uma outra ordem, dissolvendo hábitos e constroem balizas para a produção social de outros lugares.

Por exemplo, as certificações, como a do "boi rastreado", não significa apenas controle sanitário, mas também, segmentação e exclusão; significa que determinado produtor que não obtiver tal condição, sofrerá não apenas restrições de mercado mas também de respeito e confiança. 
A presença, hoje, dos tanques de expansão, nas pequenas propriedades, produtoras de leite, é outro exemplo característico da forma de disciplinar comportamentos no campo. O produtor que não tiver o equipamento em sua propriedade, é duplamente penalizado. Primeiro, de forma objetiva, quando, além de não poder entregar seu produto diretamente à cooperativa (entrega ao atravessador), tem o valor do seu produto depreciado, ainda que no momento da entrega, a análise imediata corrobore as exigências mínimas requeridas pela legislação. Segundo, moralmente, pois ele se sente impotente diante de uma realidade que o desqualifica numa prática que antes ele era "doutor".

A forma de amoldar comportamento de uma maneira impessoal, parte daquilo que Weber (1981) vai chamar do "tipo ideal" e qualquer coisa que fuja do ideal é visto como desvio e transgressão e gera punições as quais, na maioria das vezes, são punições que não são formalizadas, pois ainda, em determinadas situações, não é fornecido ao indivíduo ou ao grupo, dentro das regras, canais que o permitam expressar isto, canais de diálogo que a regra não dá, o que leva a ajustar-se, muitas vezes, preventivamente, e isto é o que Bourdieu (2001) vai chamar de violência simbólica.

Esta violência pode ser observada quando a instituição ou organização, na sua impessoalidade, na sua missão de ser modernizadora, e não apenas de ser uma instituição moderna, pode produzir outras violências simbólicas com aqueles com as quais ela precisa interagir no cumprimento de suas finalidades. Por exemplo, a instituição moderna, no setor agrícola, tenderá a interagir com os produtores na expectativa de afirmar práticas e "verdades" geradas por ela, a partir dos novos conhecimentos e inovação tecnológica, na tentativa de convencê-los a incorporá-los às suas práticas cotidianas e, dessa forma, ser reconhecida como uma instituição perita.

Então, mesmo que se diga que a inovação tecnológica que orienta a interlocução dos sujeitos, trata-se apenas de uma produção material, que tem o objetivo precípuo e o valor objetivo de ampliar certo grau de poder econômico dos agentes e da Nação, existe uma produção simbólica que vai balizar as relações éticas-econômicas entre os sujeitos envolvidos.

No processo de modernização da agricultura, o discurso produzido pelo Estado, girava em torno de aspectos bem objetivos, ou seja, visava o aumento da produção e da produtividade. Tal propósito foi alcançado, mas a custos simbólicos 
altíssimos, especialmente, ou até, exclusivamente, para os produtores familiares. A expropriação da terra, por exemplo, pode ser considerada a maior de todas as violências cometidas ao produtor familiar, pois o valor da terra para ele vai além dos fatores econômicos e de reprodução material. Significa vida, trabalho, convivência social e familiar, lugar de viver e criar seus filhos, além da relação afetiva com a natureza.

“(...) elas foram forçadas a deixar seu lugar, entendido não somente como espaço físico mas como espaço cultural, como um lugar onde foi possível criar um modo de vida caracterizado pela sociabilidade baseada nas relações com parentes e vizinhos e na religiosidade, capaz de unir a natureza, a terra, as pessoas e os santos padroeiros" (SILVA, 2004a:40).

Tal desapropriação gerou uma violência caracterizada pelo desenraizamento cultural e social, pois muitas famílias tornaram-se migrantes constantemente "verdadeiros errantes" (Id: 40), sempre em busca de trabalho, principalmente no interior de São Paulo, mas também no Mato Grosso do Sul (SILVA, 2004a).

Atualmente, no cenário agrícola, ainda em nome do aumento da produção e produtividade, formas de violência simbólica permeiam as relações entre os grupos sociais em seus processos interativos. Pegando emprestado, mais uma vez, o exemplo do plantio da cana, não esquecendo seu propósito final, as condições de trabalho às quais são submetidos os trabalhadores, remonta a tempos idos em grau de exploração. Numa entrevista, Silva (2007a), considera que elas são, hoje, ainda mais "dilapidadora" que antes.

$\mathrm{Na}$ mesma entrevista, comenta sobre o excesso de trabalho a que os trabalhadores são submetidos, sendo cada vez mais crescente as metas de produção diária exigidas pelas usinas (12 a 15 ton/dia), levando os trabalhadores à exaustão, quando não, à morte. Ela conta que de 2004 aos tempos atuais, 18 trabalhadores morreram por excesso de trabalho nas plantações de cana, no estado de São Paulo; além de outros acidentes. Os trabalhadores ainda são descartados muito cedo da atividade, pois acima de 35 anos não respondem aos níveis elevados de produtividade exigidos (SILVA, 2007a). Ele é desqualificado, não pela incompetência técnica ou desconhecimento da atividade, mas por considerá-lo um incapaz. 
Na pecuária bovina de leite, os produtores familiares não participam das negociações sobre a remuneração do seu produto, ou seja, daquilo advindo do seu esforço pessoal e familiar, que Ihe constitui um hábito e um fazer cotidiano formador da sua identidade. Está subjulgado não apenas à lógica do mercado, mas ainda à análise perita dos laboratórios e a subjetividade da cooperativa ou agroindústria.

"O produtor chega na loja e diz: eu preciso disso. Quanto é? É X. À vista é mais barato? Não. Agora quando ele chega com seu produto ele diz: quanto você paga por isso? Olha, é muito humilhante, é humilhante demais. O produtor não negocia o produto dele" (agricultor familiar B).

Tal fato, permitiu à pesquisadora, por meio da observação durante as entrevistas, perceber o grau de fragilidade nos processos de interação entre os grupos sociais envolvidos, os quais, muitas vezes, se dá de forma hierarquizada e não concede ao outro a oportunidade da negociação ou do diálogo. Outras vezes, este espaço até existe, mas a hierarquização mantém-se na oralidade ou mesmo na rigidez de suas pautas, cujo conteúdo pré-estabelecido, pouca margem tem à negociação.

Ao constatar que tais produções ocorrem a partir das lógicas de interação sociais, intensificadas no ambiente da modernidade, o próximo item contempla esta dimensão.

\subsection{A modernidade como lógica das interações sociais}

Giddens (1991) apresenta o caráter dinâmico da modernidade a partir de três elementos: descontinuidade, desencaixe e reflexividade. Cada um desses elementos apresenta características singulares, porém, complementares, retratando as interações que ocorrem nos processos sociais.

O autor assinala que ocorreram descontinuidades em várias fases do desenvolvimento histórico; contudo, detém-se apenas no conjunto daquelas associadas ao período moderno. 
"Os modos de vida produzidos pela modernidade nos desvencilharam de todos os tipos tradicionais de ordem social de uma maneira que não tem precedentes (...)" (GIDDENS, 1991:14).

“(...) as transformações envolvidas na modernidade são mais profundas que a maioria dos tipos de mudança característicos dos períodos precedentes" (GIDDENS, 1991:14).

Segundo o autor, não é contestável a existência de continuidade entre o tradicional e o moderno, pois nem um nem outro formam um todo à parte sendo, portanto, um erro contrastá-lo.

A maneira que 0 autor identifica as descontinuidades que separam as instituições sociais modernas das ordens sociais tradicionais é a partir de características como o "ritmo da mudança que a era da modernidade põe em movimento" (GIDDENS, 1991:15). Perfeitamente observável, quando em nossas rotinas, mal conseguimos apreender e internalizar determinadas práticas e procedimentos para então, muito breve, descartá-los ou reinventá-los em atendimento a uma nova ordem.

"Uma segunda descontinuidade é o escopo da mudança. Conforme diferentes áreas do globo são postas em interconexão, ondas de transformação social penetram através de virtualmente toda a superfície da Terra” (GIDDENS, 1991:15).

Terceira e última característica apontada pelo autor estar na "natureza intrínseca das instituições modernas", nunca vista em outros períodos históricos como o “(...) sistema político do estado-nação, a dependência por atacado da produção de fontes de energia inanimadas, ou a completa transformação em mercadoria de produtos e trabalho assalariado" (GIDDENS, 1991:16).

A modernidade, contudo, produz também uma dinâmica de rompimento, cujos efeitos são subjetivos e imateriais ligados, por exemplo, à tradição. Segundo Silva (2006:2):

"(...) a modernidade teve que "inventar" tradições e romper com a "tradição genuína", isto é, aqueles valores radicalmente vinculados ao passado pré-moderno. A modernidade, neste sentido, expressa descontinuidade, a ruptura entre o que se apresenta como o "novo" e o que persiste como herança do "velho". 
O que é a tradição? "A tradição, em suma, contribui de maneira básica para a segurança ontológica na medida em que mantém a confiança na continuidade do passado, presente e futuro, e vincula esta confiança a práticas sociais rotinizadas" (GIDDENS, 1991:107).

Um segundo elemento da dinâmica da modernidade abordado por Giddens (1991), refere-se aos mecanismos de desencaixe

\footnotetext{
"Por desencaixe me refiro ao "deslocamento" das relações sociais de contextos locais de interação e sua reestruturação através de extensões indefinidas de tempo-espaço" (Id.: 29).
}

Os mecanismos de desencaixe são representados por Fichas Simbólicas e Sistemas Peritos (GIDDENS, 1991):

"Por fichas-simbólicas quero significar meios de intercâmbio que podem ser "circulados" sem ter em vista as características específicas dos indivíduos ou grupos que lidam com eles em qualquer conjuntura particular" (Id.: 30).

"Por sistemas peritos quero me referir a sistemas de excelência técnica ou competência profissional que organizam grandes áreas dos ambientes material e social em que vivemos hoje" (Id.: 35).

Ambos, fichas simbólicas e sistemas peritos, dependem da confiança, esta, por sua vez, segundo Giddens (1991:87), “(...) a natureza das instituições modernas está profundamente ligada ao mecanismo da confiança em sistemas abstratos, especialmente confiança em sistemas peritos". Assim, em nossas práticas cotidianas e dinâmicas, estamos imersos em sistemas peritos nos quais depositamos inteira confiança e ficamos surpresos quando falhas são reveladas.

A exemplo disso, vale registrar o fato ocorrido recentemente, quando a sociedade brasileira, viveu uma das situações mais inusitadas, pra não dizer trágica. Um dos alimentos mais tradicional e fundamental da dieta da grande maioria dos brasileiros, foi adulterado de maneira vergonhosa por uma rede de agentes da cadeia produtiva do leite; entre peritos, empresários e fiscais do Estado. A adição de 
soda cáustica e água oxigenada no leite, com o intuito de aumentar o volume e a vida útil de prateleira, pôs em risco a qualidade do produto e, não só isso, abalou a confiança dos consumidores, pondo em suspeita toda a cadeia. Segundo especialistas, a mistura não produz risco à saúde humana, porém a falta de controle na dosagem pode ser cancerígeno (KATTAH, 2007).

O evento ocorrido, pode desestabilizar a relação de confiança nos sistemas peritos, pois a idéia estabelecida do alimento saudável e produzido sob o controle e rigor técnico, apresentou, neste caso, uma insegurança para a segurança alimentar, exigindo dos próprios peritos novas estratégias de resgate da confiança e da sua condição perita. No caso do leite, a qualidade desejada precede, em boa parte, aspectos objetivos da técnica, ou seja, fatores biológicos são importantes; sua qualidade está definida, principalmente, em dois pontos: na sanidade animal e na higiene da ordenha. Segundo especialistas, se o leite não sair da propriedade em condições desejáveis, o que vier depois, será apenas para mascarar o produto (SOUZA, 2007).

A reflexividade constitui a terceira fonte de dinamismo da modernidade. A reflexividade da modernidade significa que as práticas sociais modernas são enfocadas, organizadas e transformadas, à luz do conhecimento constantemente renovado sobre estas próprias práticas. "Nas condições da modernidade reflexiva o 'conhecer' não significa estar certo, ou seja, o conhecimento está sempre sob dúvida e incide sobre as práticas sociais e estas sobre o mesmo" (SILVA, 2006:4).

Silva (2006:4), considera que “(...) a característica reflexiva da sociedade moderna indica a possibilidade de uma contínua geração de autoconhecimento sistemático, o qual, em geral, desestabiliza a relação entre conhecimento leigo e saber especializado (sistemas peritos)".

A modernidade reflexiva rompe com o ideal iluminista, este acreditava na racionalidade e no conhecimento como instrumentos para se alcançar o bem estar e segurança social. Apostava que a crescente informação sobre o mundo social e natural resultaria num controle entre eles. Contudo, a modernidade amplia as oportunidades e também os riscos (SILVA, 2006).

Quando do processo de modernização da agricultura, acreditava-se que o uso intensivo da mecanização, dos fertilizantes e agrotóxicos e equipamentos de irrigação; representavam uma alternativa à melhoria da renda do produtor por meio do aumento da oferta de alimentos e ganhos em produtividade, além do 
desenvolvimento econômico e social. Parte dos seus anseios foram alcançados; entretanto, suas consequências, produziram, para o conjunto da sociedade, bem como para o meio ambiente, efeitos deletérios como a erosão e degradação dos solos agrícolas, deficiência da qualidade e quantidade dos corpos d'água, contaminação de alimentos, desmatamento generalizado e comprometimento da diversidade genética (VEIGA, ABRAMOVAY e EHLERS, 2003), sem contar os efeitos à saúde humana e a expulsão de pequenos produtores de suas terras.

A busca pela superação desses problemas constituiu-se em um desafio à mudança desse padrão produtivo. Desta forma, foi na reflexividade da sociedade, que as práticas vigentes passaram a ser criticadas, forçando demandas por ações mitigadoras desses efeitos. Algumas alternativas são levantadas como: plantio direto, curvas de nível, adubação verde, biofertilizantes, compostagem, lodo de esgoto e fixação de nitrogênio (VEIGA, ABRAMOVAY e EHLERS, 2003).

Assim, é no contexto do mundo moderno, que as "verdades" estão continuamente postas à prova e, não seria possível esgotar aqui, eventos e possibilidades que surgem e se renovam a todo instante, não apenas na agropecuária, mas também em outros setores da economia; fruto, muitas vezes, da sua própria contradição.

É verdade que, como afirma Giddens (1991:58-59): "A produção de conhecimento sistemático sobre a vida social torna-se integrante da reprodução do sistema, deslocando a vida social da fixidez da tradição". Porém, o conhecimento reflexivo da modernidade "esvazia" a certeza inerente a este. Isto significa que, na modernidade, a ciência é posta constantemente sob dúvida, sempre sujeita à revisão - uma certeza, um paradigma pode ser (e é) ultrapassado por novas descobertas. Dessa forma, o conhecimento sempre está sob prova e o risco de ser descartado; a reflexividade moderna potencializa este processo.

Assim, o produtor rural que tem suas práticas balizadas pela modernidade, está em constante refazimento dos seus fazeres, reinventando todo dia suas rotinas:

"Estou fazendo teste com a mãe dessa bezerrinha, tô fazendo trabalho nela especial, tô investindo em matéria prima, bastante soja, ração, algodão se eu tiver um bom resultado, quero tirar leite dela três vezes...".

(agricultor familiar E) 
sem, no entanto, se afastar por completo dos seus hábitos e seus saberes:

"A vaca melhor é aquela que tem mais úbere, quando nós vai comprar vaca aqui, nós observa aquela veia grossa do úbere, aquilo lá é o principal, aquela veia grossa".

(agricultor familiar E)

No caso da pecuária bovina de leite, muito pouco muda em suas práticas diárias: a ordenha ainda é realizada muito cedo, pois a vaca não espera; é preciso alimentar o gado e outros pequenos animais da propriedade; um conserto aqui outro acolá, até o cumprimento da sua jornada de trabalho. Mas algo é diferente, armazenar o leite já não é mais como havia aprendido com seu pai, avô etc., ou seja, o líquido era posto no latão para em seguida ser entregue ao "caminhão de leite" (na maioria das vezes era o atravessador), que passava todos os dias.

Atualmente, é necessário construir uma "casinha" ou arrumar um cantinho no espaço doméstico para instalar o "tanque de expansão" e aguardar o dia marcado em que o "caminhão tanque", com sistema refrigerado, da cooperativa, virá (Foto 2).

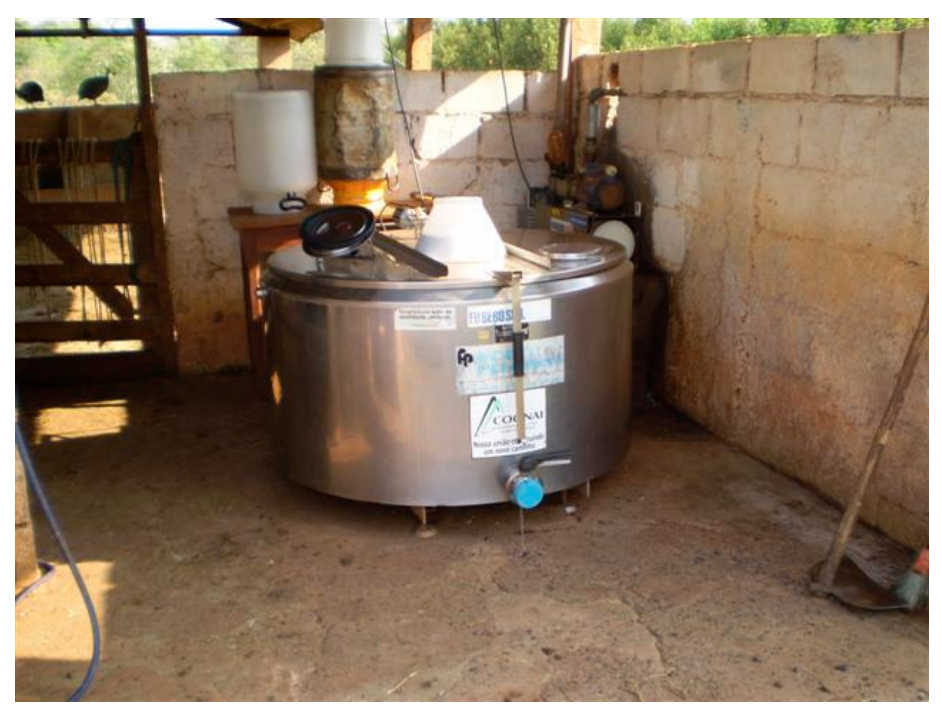

FOTO 2: tanque de expansão, instalado no espaço da propriedade, para acondicionamento do leite, até o momento da entrega ao caminhão da cooperativa.

Nessa dinâmica e, talvez, por causa dela, o conhecimento reflexivo permeia o conjunto dos grupos sociais envolvido no processo e, para garantir o mínimo de seguridade para a sociedade, é preciso que se constitua uma rede sociotécnica que 
se responsabilize mutuamente para o atendimento de tal propósito. Este é o assunto do próximo item.

\subsection{Inovação como rede sociotécnica}

Uma contribuição que, talvez, seja relevante para a compreensão dos processos de transformação na agricultura, bem como para a agricultura familiar, é a teoria da formação das redes sociais e sociotécnica que se configura neste processo.

Sua análise perpassa por um conjunto de grupos sociais, instituições e organizações públicas e privadas que buscam dar conta da dinâmica dos fatos científicos.

Silva (2004c), considera que uma rede sociotécnica corresponde a um conjunto de elementos humano e material, e ainda, políticos e sócio-econômicos, integrados, que fazem com que, uma determinada atividade exista e seja praticada de determinada forma. Para o autor, esse termo tem um sentido mais amplo do que cadeia produtiva, pois considera que a rede é definida pelas características e qualidade das relações sociais entre os diferentes agentes envolvidos. Elas devem ser baseadas na confiança, ou seja, se um agente manipula ou explora outro, a rede corre o risco de se desintegrar.

Assim, a atividade dificilmente se desenvolverá apenas pelo desejo ou interesse de um grupo específico. Da mesma forma que determinada inovação tecnológica, jamais será adotada, coletivamente, se for baseada na vontade individual de quem quer que seja. Quando a rede não se forma, a atividade não se desenvolve.

É interessante observar, que a rede produz um outro modo de conhecer as coisas. Por um lado, ela é uma forma de equacionar os problemas causados pela grande especialização dos saberes, ou seja, cada vez mais produz-se em grupo, no qual cada um contribui com um pouco do que sabe.

"A identificação dos 200 genes produtores de açúcar foi realizada em um projeto entre o Centro de Tecnologia Canavieira (CTC), a Usina Central de Álcool Lucélia e pesquisadores da Universidade de São 
Paulo (USP) e Unicamp financiados pela FAPESP" (OLIVEIRA e VASCONCELOS, 2006:65).

Por outro lado, Parente (2000:172).questiona: "(...) como saber o que se faz hoje em um mundo cujas grandes descobertas são anunciadas a cada minuto?". 0 autor salienta, que o enunciado científico, no seu desdobrar, necessita de uma infraestrutura sólida, pois acredita que: “(...) a ciência, para circular, depende de verdadeiras redes logísticas bem equipadas e instrumentalizadas" (Id:174).

No mundo moderno, as redes sociotécnicas tornaram-se uma espécie de paradigma e de elemento principal das mudanças que estão ocorrendo, especialmente no momento em que as tecnologias de comunicação e de informação passaram a exercer um papel estrutural na nova ordem mundial. A sociedade, bem como os elementos de sua dinâmica como o capital, o mercado, o trabalho, 0 conhecimento enfim são, hoje, definidos por algum tipo de rede. "Nada parece escapar às redes, nem mesmo o espaço, o tempo e a subjetividade" (PARENTE, 2007:101).

Silva (2007:1), corrobora que, na ciência, a idéia do cientista trabalhando isoladamente, é coisa do passado. Em tempos atuais, o processo de produção do conhecimento científico e da inovação tecnológica prescinde de "(...) associações, negociações, alinhamentos, estratégias e competências (...)" para garantir sua efetividade. Para a autora, ela é uma construção coletiva.

Para a construção dos fatos científicos, Latour (2000) considera a necessidade da presença de um conjunto de elementos que servirão como aporte, para que o discurso mais contundente se torne a verdade científica absoluta e se estabeleça como única. Contudo, seu processo constitutivo depende do compromisso de outros. Assim, “(...) determinada afirmação pode até ser feita por um único indivíduo, mas a construção de fatos e inovações, propriamente, é um processo coletivo" (OLIVEIRA, 2007:22).

Ao pensarmos, por exemplo, no fenômeno da produção do etanol a partir da cana-de-açúcar, cuja tecnologia gera energia limpa, e existe uma demanda mundial; Latour (2000) sintetiza uma base para a sua elaboração, na qual considera que todos caminham numa mesma trajetória; a idéia então, é chamada de invenção. A partir daí, passa-se ao desenvolvimento, para em seguida serem fabricados modelos e multiplicados em milhares de exemplares para serem vendidos no mundo todo. 
O exemplo ilustra, neste caso, a multiplicação de plantações de cana que se espalharam pelo País, obedecendo a padrões de configuração do espaço e da técnica de produção; além da construção de novas usinas e o próprio conjunto da tecnologia.

Desta forma, se multiplicam as redes sociotécnicas a exemplo da Rede Interuniversitária para Desenvolvimento do Setor Sucroalcooleiro (Ridesa), a qual além da Universidade Federal Rural de Pernambuco (UFR-PE), fazem parte mais sete universidades federais: Alagoas (Ufal), Goiás (UFG), São Carlos (UFSCar), Viçosa (UFV), Paraná (UFPR), Rural do Rio de Janeiro (UFRRJ) e Sergipe (UFS) que são responsáveis por desenvolverem novas variedades de cana-de-açúcar (OLIVEIRA e VASCONCELOS, 2006).

Para que o fato científico se estabeleça e não tome rumos outros que não aquele pensado inicialmente (embora o risco seja iminente, pois é uma construção social e depende dos interesses envolvidos) é preciso que ele seja incorporado pela rede constituída. Tal incerteza paira no ar e, para mitigar isto, é necessário convocar outras pessoas a fim de que elas participem da sua construção, além de tê-las sob controle e prever suas ações (OLIVEIRA, 2007).

Nesse mesmo raciocínio, Latour (2000:203) usa a expressão "sistema de alianças", o qual significa que o idealizador da inovação precisa consolidar alianças e não se distanciar daquilo que deseja manter sobre controle. Desta forma, ainda que uma rede tenha elementos fortes, àqueles considerados mais fracos pode desintegrá-la completamente.

Nas comunidades rurais, provida por grande número de propriedades familiares, existem diferentes formas de organização como a igreja, a escola, o grupo de futebol, o sindicato, a associação e a cooperativa, entre outros. Estas formas organizativas, podem ser consideradas um tipo de rede e caracterizam um capital social que pode otimizar ou viabilizar um processo de desenvolvimento, pois a sua coesão pode levar a ações coletivas em busca de um maior acesso à informação, poder de negociação e político e engajamento para o alcance dos seus objetivos (BIANCHINI, 2007).

Vale salientar, que a estruturação das redes sociotécnicas não se dá de maneira harmônica, pois a interface entre os diferentes e diversos grupos envolvidos gera momentos de tensão e conflitos. Normalmente, os grupos envolvidos, apresentam um discurso próprio; na maioria das vezes, registrado formalmente, e 
que deve nortear a elaboração e execução das propostas de trabalho. Entretanto, é comum existir um desalinhamento entre o discurso e a prática de alguns grupos envolvidos.

Latour (2001), na sua obra, afirma que as rupturas que o processo da modernização criou entre os mundos da vida humana e natural, e seus desdobramentos, foram produzidas para "separar" e "manter" cotas de poder de grupos, e que estes desdobramentos e suas práticas de legitimação devem ser vistas como práticas de manutenção do poder; norteadas por uma subjetividade ou determinada crença. Acredita-se, por exemplo, que a aquisição de um animal, com certas características e supostos atributos de qualidade, cuja origem proceda de uma região tradicionalmente criadora ou de grandes leilões, justifique que o produtor pague um preço maior por ele; ou, ainda, que a incorporação de uma determinada tecnologia, justifica o investimento realizado com vistas à sua manutenção no mercado ou a conquista de outros. Diante disso, Latour (2001:346) afirma que: "não existe nenhuma realidade sem representação".

Diante do pressuposto, é salutar a abordagem de que a produção/construção dos fatos científicos tenha como referência à negociação, pois há uma série de interesses de diferentes grupos sociais envolvidos (LATOUR, 2000). Daí a necessidade de se conhecer a conformação das relações entre os atores.

No conjunto das ações propostas pelo Estado, no que se refere à modernização da agricultura, a construção de uma rede sociotécnia foi importante; entre elas as diferentes esferas ligadas ao próprio Estado, instituições de pesquisa, instituições financeiras, empresas nacionais e multinacionais para que suas propostas fossem viabilizadas e efetivadas. A estrutura da rede depende do objetivo proposto, por isso se diferencia no conjunto dos atores envolvidos. Contudo, em qualquer que seja a rede, é importante que cada ator assuma a responsabilidade que lhe foi atribuída, pois é na congruência entre eles que os objetivos podem ser alcançados.

$\mathrm{Na}$ busca de alternativas mais sustentáveis para o desenvolvimento da agropecuária, algum horizonte de possibilidade surge a partir de grupos sociais entre eles técnicos, ONG's, grupos de agricultores e diferentes agentes ligados à agricultura familiar e que foi denominado "Rede de Viabilização da Agricultura Familiar”. Tal proposta tem como princípios: “(...) a cooperação agrícola, a agroecologia, a solidariedade entre os grupos de agricultores, o resgate da cultura e 
conhecimento local, a participação democrática, a auto-gestão, etc." (BADALOTTI e REIS, 2005:125).

No projeto, objeto desse estudo, de forma sucinta, a rede sociotécnica é formada pelos atores: Ministério da Agricultura, Pecuária e Abastecimento - MAPA, responsável pelas políticas públicas; Embrapa Pecuária Sudeste, idealizadora do projeto em execução; Coordenadoria de Assistência Técnica Integral - CATI, beneficiada e responsável por ações de transferência aos produtores; Prefeituras Municipais, apoio institucional e logístico; Fundação de amparo à Pesquisa do Estado de São Paulo - FAPESP, apoio financeiro e os agricultores familiares beneficiários do projeto (EMBRAPA, 2004a).

Tal conformação, traz em seu bojo um conjunto de interesses distintos, o qual pode gerar pontos de tensão, conforme explicado anteriormente. Assim, uma alternativa para mitigar eventuais conflitos pode estar no conhecimento sobre as representações sociais que os diferentes atores têm sobre os papéis de cada um ou em relação ao próprio objeto de desejo. No próximo item discorreremos sobre as representações sociais no contexto da modernidade.

\subsection{Representações sociais sobre a modernidade}

O campo de estudo teórico e prático associado às representações sociais é vasto e complexo. Alguns pesquisadores reconhecem o próprio conceito de representação social como algo que apresenta múltiplas faces e que vai ao encontro dos interesses tanto dos psicólogos sociais quanto dos sociólogos e educadores.

Arruda (2002) considera a definição mais consensual entre os pesquisadores, àquela descrita por Jodelet (2002): “As representações sociais são uma forma de conhecimento socialmente elaborado e compartilhado, com um objetivo prático, e que contribui para a construção de uma realidade comum a um conjunto social" (JODELET, 2002:22).

A autora amplia esse conceito e permite uma maior compreensão sobre a TRS:

"A Teoria das Representações Sociais - TRS - operacionalizava um conceito para trabalhar com o pensamento social em sua dinâmica e em sua diversidade. Partia da premissa de que existem formas 
diferentes de conhecer e de se comunicar, guiadas por objetivos diferentes, formas que são móveis (...)" (ARRUDA, 2002:129).

Vale salientar que Moscovici (2005), um dos iniciadores da pesquisa sobre representações, aponta que apesar destas estarem espalhadas no cotidiano das pessoas, o seu conceito é difícil de ser apreendido.

Nas palavras de Moscovici, representação social é:

“(..) um sistema de valores, idéias e práticas, com uma dupla função:

(...) estabelecer uma ordem que possibilitará às pessoas orientar-se em seu mundo material e social (...) possibilitar que a comunicação seja possível entre os membro de uma comunidade, fornecendo-lhes um código para nomear e classificar, sem ambigüidade, os vários aspectos de seu mundo e da história individual e social" (Moscovici, 2005:21).

Este autor aproxima a representação social do conhecimento do senso comum, afirmando que as pessoas encontram-se diante de um conjunto muito extenso de conhecimentos científicos aos quais têm acesso por meio dos mais variados modos, como por exemplo, os meios de comunicação de massa e mesmo as suas relações interpessoais.

A estrutura destes conhecimentos, segundo o autor, é complexa e para apropriar-se dos mesmos as pessoas tendem a reduzi-lo e simplificá-lo, cujo objetivo é tornar tais conhecimentos compreensíveis, existindo, portanto, todo um esforço criativo das pessoas em torná-los elementos do senso comum, a fim de explicar a sua realidade.

Nesta perspectiva, elaborar representações pressupõe uma organização lógica e criativa do pensamento. Para Moscovici:

"Quando tudo é dito e feito, as representações que nós fabricamos duma teoria científica, de uma nação, de um objeto, etc. - são sempre o resultado de um esforço constante de tornar comum e real algo que é incomum (...) E através delas nós superamos o problema 
e o integramos em nosso mundo mental e físico, que é, com isso, enriquecido e transformado" (MOSCOVICl, 2005:58).

A elaboração destas representações, no entanto, depende da atitude que as pessoas têm com a realidade e sua relação com a mesma, a qual se dá por meio de trocas com o ambiente social em que está inserido, seja a partir de leituras ou diálogos exercidos num contexto sócio-cultural.

São nas dinâmicas interativas, que a Teoria das Representações Sociais vai refletir sobre como os indivíduos, os grupos, os sujeitos sociais constroem seu conhecimento a partir da sua inserção social, cultural e política, por um lado e, por outro, como a sociedade se propõe a conhecer e constrói esse conhecimento com os indivíduos e seus grupos.

Busca conhecer como estes atores interagem para construir uma nova realidade e os fazem, muitas vezes, em estreita parceria; viabilizada pela linguagem e dialogicidade, confirmado por Moscovici (2005) "(...) é através dos intercâmbios comunicativos que as representações sociais são estruturadas e transformadas.", e ainda, "Em todos os intercâmbios comunicativos, há um esforço para compreender o mundo através de idéias específicas e de projetar essas idéias de maneira a influenciar outros (...)" (MOSCOVICI, 2005:28).

Deste modo, a construção das representações sociais lança mão de aspectos relacionados aos valores, crenças, condições materiais de vida, entre outros; os quais ocorrem em um determinado período histórico em que são produzidos e circulam o conhecimento científico.

Para Moscovici (2005) interessa saber o ambiente ou espaço em que as representações ocupam em uma sociedade do conhecimento. Este, anteriormente, segundo o autor, seria determinado em esferas distintas entre a sagrada e a profana. Atualmente, estas esferas foram abandonadas e substituídas por universos consensuais e reificados. Porém, são nesses mundos opostos que se constroem e determinam, dentro de cada cultura e do indivíduo, a força de sua identidade a partir daquilo que lhe é próprio e pode ser mudado e aquilo que é do "outro" e que pode Ihe fazer mudar.

O universo consensual é constituído principalmente no diálogo informal, nas relações cotidianas, enquanto que o universo reificado se evidencia no espaço científico, com sua linguagem própria e hierarquia interna (ARRUDA, 2002). 
Contudo, segundo esta mesma autora, estas duas formas distintas presentes em nossas sociedades, ou seja, a consensual e a científica, cada uma gerando seu próprio universo, a diferença entre ambas, neste caso, "(...) não significa hierarquia nem isolamento entre elas, apenas propósitos diversos" (ARRUDA, 2002:130).

Moscovici (2005), entretanto, considera que o contraste entre os dois universos provoca um impacto psicológico, pois enquanto a ciência é o veículo pelo qual compreendemos o universo reificado, são nas representações sociais que se configura o universo consensual.

Desta forma, o primeiro tem a finalidade de determinar as forças, objetos e acontecimentos “(...) que são independentes de nossos desejos e fora de nossa consciência e aos quais nós devemos reagir de modo imparcial e submisso" (MOSCOVICI, 2005:52). Enquanto que a finalidade do segundo, é restaurar “(...) a consciência coletiva e lhe dão forma, explicando os objetos e acontecimentos de tal modo que eles se tornam acessíveis a qualquer um e coincidem com nossos interesses imediatos" (MOSCOVICI, 2005:52).

Na sociedade moderna, na qual a produção do conhecimento se intensifica e se renova a cada instante, Moscovici (2005) considera que ambas, ciência e representações sociais, são tão distintas entre si quanto complementares. Nesse contexto, o mundo reificado aumenta com a multiplicação das ciências, daí a necessidade de reproduzi-lo a um mundo mais acessível e imediato, ou seja a um mundo consensual e re-aprendido.

Assim, de acordo com o autor, é necessário dar a este novo conhecimento uma feição familiar e para isso, lança mão de dois mecanismos e, como disse Arruda (2002), podem ser duas faces da mesma moeda. Esses mecanismos objetiva transformar algo não-familiar em familiar, num desenrolar que parte da nossa percepção particular; comparamos, interpretamos para depois reproduzi-lo em algo concreto, visível e que podemos controlar.

O primeiro, refere-se à ancoragem: este diz respeito ao processo que dá sentido ao objeto apresentado à nossa compreensão, ou seja, é o meio pelo qual o conhecimento se estrutura no social e volta a ele (ARRUDA, 2002).

Moscovici (2005:61), diz que ancorar significa “(...) classificar e dar nome a alguma coisa", num processo em que, primeiramente, a confrontamos às nossas categorias particulares, comparando-a com uma outra categoria que julgamos ser apropriada, ajustando-a ao seu próprio mundo. 
O segundo mecanismo é a objetivação; neste, o propósito é “(...) transformar algo abstrato em algo quase concreto, transferir o que está na mente em algo que exista no mundo físico" (MOSCOVICI, 2005:61). Assim, o objeto que antes parecia inacessível, torna-se tocável e acessível.

No contexto da modernização da agricultura, a interação entre os universos reificado e consensual produziu momentos de tensão e conflitos na tentativa de ancorar nas práticas do segundo, as recomendações do primeiro, a fim de que se estabelecesse como condição única ao desenvolvimento econômico e sócioambiental.

As políticas engendradas com vistas à reestruturação da agricultura, levaram à exclusão deste processo, grande parte dos produtores rurais, em especial os da agricultura familiar. Para os deserdados dos supostos benefícios advindos dessa modernização, ficou ancorada a idéia de que tornar-se um migrante e ter seus meios de produção expropriados, fosse algo predestinado, coisa do destino e, que, portanto, só Ihe restava a sujeição do que há por vir (SILVA, 2004a).

Os discursos em prol de práticas modernas se renovam e multiplicam-se a cada dia, geralmente obedecendo a uma ordem hegemônica, na qual as novas práticas devem estar balizadas e novas sínteses formuladas. O agricultor familiar pecuarista de leite, nas últimas décadas, precisou adequar-se às novas exigências da legislação para o atendimento aos mercados interno e externo, levando-o a um processo de reconstrução das suas práticas e reorganização da sua propriedade; a fim de atender os preceitos modernos e tornar-se um "produtor de leite" inserido na modernidade. Tal circunstância, leva a nova ressignificação dos seus fazeres e até mesmo da sua própria imagem enquanto produtor:

\footnotetext{
"Ele [projeto] fez a gente virar profissional... Antigamente tem muito esse ditado...eles falam, vocês não são produtor, vocês são isso...! Não, hoje em dia não, hoje em dia nós já está sendo produtor de leite sim. A gente tá fazendo produção em hectare...". (agricultor familiar B)
}

Desta forma, uma estratégia adotada pelas instituições modernas para ancorar novas práticas na tradição da ruralidade, pode ser a indução, cotidianamente, de 
novos valores, conceitos e padrões tecnológicos, os quais as fazem acreditar da sua necessidade enquanto propulsoras do bem-estar da sociedade.

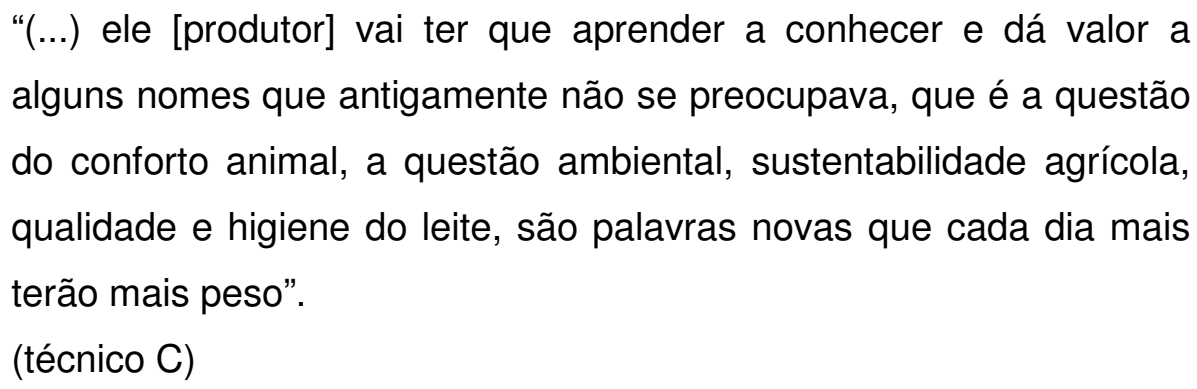
alguns nomes que antigamente não se preocupava, que é a questão do conforto animal, a questão ambiental, sustentabilidade agrícola, qualidade e higiene do leite, são palavras novas que cada dia mais terão mais peso". (técnico C)

As dinâmicas produzidas nas relações sociais e sua interação com outros setores da sociedade, foram construídas ao longo do tempo sob bases contraditórias, principalmente no espaço rural, potencializadas nas sociedades modernas. No item a seguir, abordaremos alguns desses aspectos.

\subsection{A modernidade e suas implicações no mundo rural}

Grande parte da literatura em sociologia rural desenrolou-se dedicando-se aos aspectos negativos que a chamada modernização conservadora legou ao meio rural no Brasil.

O aumento da tecnificação rural “(...) baseado na utilização intensiva de fertilizantes químicos e em processos mecânicos de reestruturação e condicionamento de solos (...)" Romeiro (1998:93) - colaborou com o processo concentracionista da terra, convertendo em migrantes uma população sem acesso aos meios de produção fundamentais, gerando conflitos e distorções no contexto das relações de trabalho, de comunidade, de família, bem como do homem com a natureza.

As políticas de créditos que os sucessivos governos elaboraram provocaram uma rede de proteção às chamadas commodities (como a soja) e penalizaram a produção interna e de baixa escala ao mesmo tempo em que converteram em área produtiva grandes extensões territoriais, gerando impactos ambientais severos em ecossistemas já fragilizados. Mais recentemente, as diversas atividades no campo e as inovações ajustadas a produtores de pequena produção, permitiram algum horizonte de valorização de um modo de vida tradicional. 
Conforme descrito por Silva (1999a), o meio rural brasileiro já não pode mais ser analisado apenas como um conjunto das atividades agropecuárias e agroindustriais. O aparecimento e a expansão dessas "novas" atividades rurais, têm propiciado outras oportunidades para muitos produtores. Neste contexto, Silva (1999) reconhece que, tanto na indústria quanto na agricultura, as novas tecnologias já estão não só alterando profundamente as formas de organização do processo de trabalho, mas também redefinindo os requisitos fundamentais de sua localização espacial. Agora o espaço rural já não mais se limita a cumprir funções produtivas agrícolas e alimentares. Ganha novas atribuições, que permitem o desenvolvimento de múltiplas atividades produtivas e ocupacionais, como o consumo de bens materiais e simbólicos (festas, folclore, rituais etc.) e de serviços (ecoturismo, atividades de preservação ambiental etc.), ou seja, a pluriatividade.

Porém, permanece hegemônica a preocupação com a elevação da produtividade em quaisquer escalas, de forma que as questões relacionadas com o meio ambiente e seus recursos naturais sejam negligenciadas. De acordo com Sachs (1986), existem seis princípios básicos de uma nova política de desenvolvimento centrada na sustentabilidade: satisfação das necessidades básicas, solidariedade com as gerações futuras, participação da população envolvida, preservação dos recursos naturais e do meio ambiente, elaboração de um sistema garantindo emprego, segurança e respeito a outras culturas e programas de educação. Isso coloca em xeque o modelo técnico vigente até então (Bonny, 1993). O modelo produtivista, que demanda grande necessidade de capital e energia, provoca inúmeros danos ambientais além de apresentar elevados custos de suporte dos mercados.

De acordo com a Agenda 21 (CNUMAD, 1992), com o objetivo de criar condições que permitam o desenvolvimento rural e agrícola sustentável, verifica-se a necessidade de efetuar importantes ajustes nas políticas para a agricultura e o meio ambiente, tanto no nível nacional como internacional, nos países desenvolvidos e nos países em desenvolvimento.

Um dos aspectos buscado é o aumento da produção e distribuição regular de alimentos, bem como o acesso a estes pela população em geral, a partir da melhoria da renda familiar, de modo a incrementar a segurança alimentar. Esta, por sua vez, não apenas refere-se ao provimento de alimentos, mas "É a condição para a existência de uma sociedade organizada (...)", como afirma ABAG (1993:26): 
segurança alimentar é definida “(...) como o acesso assegurado a todas as pessoas, em todos os tempos, ao alimento necessário a uma vida saudável".

Para tanto, é necessário assegurar uma oferta estável de alimentos, nutricionalmente adequados, de fácil acesso por parte dos grupos vulneráveis, paralelamente à produção para os mercados; emprego e geração de renda para reduzir a pobreza; dentre outros, como iniciativas do Estado na área da educação. Assim, o uso de incentivos econômicos e o desenvolvimento de tecnologias novas e apropriadas foram necessários e impostergáveis.

Há três décadas, a Embrapa - Empresa Brasileira de Pesquisa Agropecuária, vinculada ao Ministério da Agricultura, Pecuária e Abastecimento, vem cumprindo um papel nesse sentido, fortalecendo suas interações e parcerias com universidades, empresas públicas e privadas, instituições voltadas para a pesquisa agropecuária nacional, como aquelas pertencentes ao Sistema Nacional de Pesquisa Agropecuária (SNPA).

Neste contexto e no conjunto das ações públicas, foram igualmente envolvidas as Secretarias Estaduais e Municipais da Agricultura, que devem se comprometer em viabilizar as políticas locais; a instituição financeira, na concessão do crédito rural e, em especial, os serviços de assistência técnica e extensão rural, como, por exemplo, as Empresas de Assistência Técnica e Extensão Rural - EMATER's, existentes em alguns Estados como Minas Gerais, Rio de Janeiro e Paraná; e a Coordenadoria de Assistência Técnica Integral - CATI, órgão ligado à Secretaria da Agricultura do Estado de São Paulo. Ambos são responsáveis por fazer chegar ao setor produtivo as tecnologias geradas. Num trabalho estratégico para implementar ações como de segurança alimentar.

Desta forma, está constituída uma rede sociotécnica que pretende organizar o projeto de modernização no campo, na qual a agricultura familiar foi ganhando destaque no entendimento de seus problemas, formulações e implementações das soluções.

Contudo, o êxito do desenvolvimento rural e agrícola sustentável depende em ampla medida da participação ativa de todos os sujeitos envolvidos.

A relativa evidência que a agricultura familiar vem apresentando no cenário nacional, se deve, em parte, a crescente abertura que se deu à sua participação em arenas decisórias como alguns conselhos gestores. A criação destes, inclusive, constitui uma importante inovação institucional das políticas públicas no Brasil, pois 
apresentam um potencial considerável às transformações políticas às quais estão vinculados. Entretanto, muitos estudos revelam a precariedade das ações e participação desses organismos, os quais, não raras vezes tornam-se subservientes às lógicas dominantes locais (ABRAMOVAY, 2001).

Foi a partir da década de 1990, que surgiram os indícios de que o Estado havia esgotado as formas habituais de gestão das políticas públicas, passando-se a reconhecer a necessidade de implementar formas diferenciadas e mais participativas de gerir suas ações.

Na história recente do País, o exemplo de relativo êxito, de política pública, em benefício da agricultura familiar é o Programa Nacional de Fortalecimento da Agricultura Familiar - PRONAF, advindo de um conjunto de reivindicações de movimentos sociais, no qual incluiu-se àquelas relacionadas à agricultura familiar. Neste sentido, para que os agricultores pudessem ter acesso aos seus benefícios, criou-se o espaço institucional dos Conselhos Municipais de Desenvolvimento Rural - CMDR, como arena de participação e legitimação para a condução das propostas locais (ABRAMOVAY, 2001).

O CMDR representa apenas um dos exemplos das arenas de decisão, cuja presença do agricultor familiar se faz necessária ao exercício da sua participação como co-gestor, fiscalizador e avaliador no processo. Entretanto, esta participação não significa a ausência de outros agentes em disputa. Ao contrário, agentes governamentais e sociais também atuam no processo de deliberação e, em alguns casos, com significativa capacidade de orientação dos resultados para 0 atendimento dos seus interesses. Diante disso, Abramovay (2001:2), considera importante a existência de "uma extensa e capilarizada rede de conselhos voltada à mobilização das forças vivas que compõem o meio rural brasileiro".

Outras arenas importantes são as cooperativas, sindicatos e associações de produtores rurais. Entretanto, os agricultores familiares, por sua vez, ainda apresentam fragilidades em termos da sua organização, que resulta em claras limitações para uma intervenção mais autônoma e ativa nestes espaços, conforme revelado pelo produtor:

“(...) associação é complicadíssimo! Precisa ter na região uma filosofia de que eu sou seu companheiro você é meu companheiro, nós trocamos pra conseguirmos ir melhor".

(agricultor familiar F) 
A existência dos espaços de participação institucionalizados, não significa, entretanto, que o agricultor familiar é chamado de fato à participação, revela-se, na maioria das vezes, uma peça figurativa, formadora de quorum. Em alguns casos, como as cooperativas, são vistos apenas como possibilidade de acesso ao mercado, tanto para a venda do produto quanto para a aquisição de insumos:

"No caso é a cooperativa, a cooperativa que é balizador nosso, por exemplo, ligo na cooperativa e ligo em mais duas firmas".

(agricultor familiar B)

A exemplo do estudo realizado pelo consórcio EMATER/DESER, no Paraná (Abramovay, 2001), a própria estrutura hierarquizada das arenas participativas, com seus cargos de nomes "pomposos" como "Diretor/Presidente", "Secretário", "Fiscais" etc restringe, algumas vezes, a participação daquele que é apenas um "membro" e que, portanto, sem visibilidade ou grande importância. Embora esta relação pareça ser horizontal, na prática, ela se dá de forma verticalizada pela sua própria estrutura.

Pegando este gancho, no processo de transferência do conhecimento científico e da inovação tecnológica, este fenômeno pode se dar, quando, por exemplo, o técnico pressupõe estar negociando com o produtor, mas de fato está implícita a relação verticalizada pela hierarquia de saberes, socialmente construída, criando a falsa impressão de que a interação entre eles foi destituída da relação de poder, mas às vezes isso não é uma realidade:

\footnotetext{
"A decisão é conjunta né? Você trocando idéia com ele [técnico], vê o que dá melhor, eles te orienta e você procura fazer... Você tem que acreditar".

(agricultor familiar A).
}

A compreensão, pelo conjunto dos usuários, da função social e relevância das arenas participativas, enquanto oportunidade de intervenção, reivindicação e solução dos seus problemas, perpassa pelo exercício da comunicabilidade e práticas que ampliem a confiança entre seus membros.

Freyre (1971) ajuda a entender as razões da eventual ausência de dialogicidade que persiste na cultura de comunicação da extensão rural: trata-se de uma interlocução, historicamente autoritária. Há imposição de modelos quando, por 
exemplo, muitos produtores, são obrigados a abandonar determinadas práticas, sob a ameaça de que não sobreviverão ao mercado.

Em termos simbólicos, significa um certo rompimento com um saber construído no âmbito das suas relações pessoais e de grande afinidade. Será necessário um reaprender a partir de um esforço contido pelo desejo de não desprender-se completamente do seu capital cultural aprendido e apreendido. Consiste numa nova assimilação que envolve classificação e ressignificação para que nova síntese seja produzida. De acordo com Freire (1983), o processo de aprendizagem só ocorre quando o indivíduo é capaz de internalizar o objeto de conhecimento, reinventá-lo e incorporá-lo às suas práticas concretas.

Tal processo imprime a cada indivíduo ou grupo um ritmo próprio, o qual na maioria das vezes não atende ao compasso ditado pelas novas técnicas - que, em tempos atuais, não sustentam por muito tempo sua verdade - gerando ansiedade, angústia e sentimento de fracasso, ou mesmo de exclusão.

"Igual Ihe falei, nunca cuidei do pasto, nem calcário eu nunca pus. Precisa calcário, o problema são as condições. É igual o café, os outros [técnicos] falam: tem que cuidar direito, mas eu não tenho trator, que jeito eu vou cuidar direito".

(agricultor familiar $\mathrm{G}$ ).

"Mas tem área, mas tem morro, o gado vai, mas não tem jeito de fazer os piquete... A maioria é caída".

(agricultor familiar C).

Para o produtor, realizar determinada atividade traz em seu bojo o conteúdo da sua memória afetiva, a qual significa que o ato de produzir a ação vai além do objeto concreto, é importante que as coisas sejam feitas como ele aprendeu e constitui um hábito. Se não fosse assim, o que explicaria, então, o produtor realizar a ordenha manualmente e de cócoras (sem o apoio do banquinho preso à cintura) e ao ser interpelado, pela pesquisadora, se tal postura não era desconfortável, ele responde: "é o meu jeito, acho melhor assim".

Estes são alguns aspectos objetivos do significado simbólico, os quais estão vinculados aos fazeres tradicionais do produtor e sua relação com o entorno. Outros, entretanto, podem ser produzidos subjetivamente, quando, por exemplo, espaços 
para uma comunicação efetiva entre grupos sociais distintos, envolvendo agricultores familiares, são negligenciados; ou, quando existe, a relação ocorre numa via de mão única. A hierarquização de saberes, em alguns casos, pode potencializar isto; congestionando esta via ou interrompendo-a. Neste caso, o diálogo ocorre de maneira frágil e inconsistente, prevalecendo a prática histórica de sobreposição hierarquizada de saberes e não sua complementariedade.

A aproximação entre indivíduos ou grupos diferentes, quando se almeja o entendimento e a cumplicidade, se faz a partir do “(...) diálogo franco, adotando uma postura de reciprocidade no falar, ouvir e de receptividade em aprender" (RUAS et al, 2006:34).

Freire (1996:113) nos instigue à reflexão:

\footnotetext{
"Se, na verdade, o sonho que nos anima é democrático e solidário, não é falando aos outros, de cima para baixo, sobretudo como se fôssemos os portadores da verdade a ser transmitida aos demais, que aprendemos a escutar, mas é escutando que aprendemos a falar com eles" (grifo do autor).
}

Além do aspecto da importância da dialogicidade no processo de interação entre os indivíduos, a presença no espaço do "outro", também deve ser permeada por cuidados que não imprima a ele a obrigatoriedade do pensar, agir e de valores que não lhe são próprios, tornando-o mero objeto da ação daquele com quem pretende interagir (FREIRE, 1983).

Atualmente existe um esforço, por parte do Estado, via conselhos, conforme vimos anteriormente, de estreitar essa aproximação, mas ele ainda é incipiente, pois não é apenas uma questão de criar um instrumento político, mas, de se eliminar as vaidades pessoais.

\footnotetext{
"Até atingir todos os produtores, se eles vão fazer eu não sei, mas o que a gente quer é que eles tenham acesso a essa informação, se eles vão fazer o que a gente tá falando isso é problema deles... Nós já demos nossa contribuição... Ensinamos o sujeito a pensar e ele não vai desaprender...".

(técnico D)
} 
Em termos materiais, a indução à modernização, desconsidera os meios de produção e as técnicas constituídas no lugar, ou seja, da tradição, em favor de uma adaptação agressiva que os produtores têm que fazer para adequarem-se aos patamares de produtividade e competitividade que as cadeias produtivas às quais estão atrelados Ihes impõem. Conforme Silva (1981:105):

“(..) as mudanças tecnológicas na indústria de máquinas e equipamentos agrícolas, mostra claramente que o sentido da inovação pouco tem realmente a ver com as ditas 'necessidades dos agricultores dos países de agricultura atrasada'. Ao contrário, a inovação tecnológica parece ser um componente de decisão restrita às empresas multinacionais (...)".

O período que compreendeu as décadas de 1920 e 1950, mais precisamente em meados desta última, caracterizou-se por uma mudança na economia brasileira, à qual diz respeito ao processo de industrialização, ou seja, o país deixa de ter sua base produtiva nos padrões agrícolas para tornar-se uma economia industrial. É neste período que se intensificou o aparecimento de novas indústrias, especialmente àquelas voltadas para a produção agrícola como máquinas de beneficiar arroz e moedoras de grãos e cana-de-açúcar, considerados maquinários de pequeno porte. Mas, também, começaram a aparecer aquelas de porte mais robusto e pesado como os arados e grades de disco, peças para as usinas de açúcar e veículos agrícolas (MÜLLER, 1989).

Tal estrutura foi viabilizada pelo capital externo, empresas internacionais produtoras de equipamentos pesados, como a "International Harvester Máquinas e a Metalúrgica Dedini" (Müller, 1989:29), entre outras; são elas que revolucionaram o comércio, acelerando o processo de dependência da agricultura à indústria e sua vinculação com o capital internacional. Desta forma, em 1980, a agricultura brasileira encontra-se completamente incorporada à forma industrial de produzir, dando claros indícios da sua indissociação à indústria (MÜLLER, 1989).

De acordo com Silva (1999b), o período de 1991-94 o crescimento das vendas de tratores de esteira, tratores de rodas e colheitadeiras, ocorreu de forma intensa e contínua; principalmente nas culturas de algodão, cana-de-açúcar e café. 
Uma vez já integrada à indústria, a agricultura brasileira vai confrontar-se com empresas e grupos econômicos com grande poder para influenciar a dinâmica das suas atividades, exigindo transformações em suas estruturas e sendo pressionadas pelos interesses das oligarquias de poder econômico que surgem internamente ao setor. Vale salientar, que esta industrialização da agricultura brasileira se deu por fortes subsídios ao crédito e incentivos fiscais ao capital, promovidos pelo próprio Estado por meio das suas políticas, estimulando os setores industriais ligados a ela a produzirem dentro de padrões para o mercado internacional (AGUIAR, 1986).

Este processo de mudança ocorrido na agricultura, leva ao desencadeamento de outros fenômenos como a própria disseminação do progresso técnico e as concentrações do conhecimento científico e do capital. Entendendo, ainda, como progresso técnico, a incorporação do “(...) potencial científico e tecnológico ao conceito de industrialização do campo" (Müller, 1989:43).

O modelo proposto para a agricultura brasileira era baseado na monocultura de exportação, dedicando menor relevância à produção de alimentos para o consumo interno. Esta, entretanto, advinha de pequenas explorações situadas tanto nos limites nas grandes propriedades na forma de subsistência, quanto de áreas próximas da fronteira agrícola realizada por uma população que necessitava complementar sua renda, sendo então caracterizada pela ocupação de áreas residuais (ROMEIRO, 1998).

A modernização da agricultura baseada na produção da monocultura agrícola, desestruturou várias relações existentes nas sociedades pré-capitalistas, como as relações comunitárias tradicionais.

Diante dos baixos rendimentos apresentados pelas culturas agrícolas mais importantes, economicamente, como a soja e o milho, à época, e aliado a padrões vigentes de cumulação, se faz premente uma nova forma de intervenção, qual seja, dos agentes biológicos para alcançar ganhos de produtividade, bem como a resistência e o controle das pragas e doenças que ameaçavam as lavouras. Assim, - Estado tornou-se indutor e promotor das pesquisas voltadas para a inovação biológica e genética (GOODMAN, D.; SORJ, B. e WILKINSON, J. 1990).

Ainda que o fenômeno da industrialização da agricultura, tenha ocorrido no contexto do setor como um todo, sua dinâmica acontece de forma diferenciada entre a produção de grãos e a de animais. Para o setor pecuário, a capacidade de assimilação e incorporação dos avanços tecnológicos foram melhor absorvidas que 
o setor agrícola, especialmente para equipamentos elétricos e computadorizados. Mas, também, a engenharia genética foi incorporada pela atividade pecuária.

Os avanços obtidos com a biotecnologia levam a novas configurações do espaço no campo e, no caso particular da pecuária, pela grande mobilidade dos animais, a importância da terra, como espaço produtivo, diminuiu; visto que a obtenção do alimento, como as forragens, pôde ser adquirida industrialmente e em locais concentrado, viabilizados, posteriormente, pela agricultura especializada (GOODMAN, D.; SORJ, B. e WILKINSON, J. 1990).

Aspectos como a redução de mão-de-obra para a pecuária pode ser observado em função da automação de algumas fases da produção que antes eram realizadas manualmente como a ordenha e o preparo da forragem. Neste contexto, cresce o número de indústrias especializadas em tais produtos; neste caso, a ordenha mecânica e a forragem processada e formulada por computador; além dos produtos farmacêuticos como vacinas e antibióticos (GOODMAN, D.; SORJ, B. e WILKINSON, J. 1990).

$\mathrm{Na}$ trajetória da produção agrícola brasileira, tanto na agricultura como na pecuária, a engenharia genética adquiriu um futuro promissor, pois a sua aplicação comercial tornou-se crescente e encontrou no capital industrial seu maior fomento para as pesquisas biológicas, a exemplo das fertilizações "in vitro", clonagem, produção de hormônios, plantas geneticamente modificadas, entre outros.

A interação da indústria com os fatores da natureza, no entanto, não produz uma relação nada harmônica; sintetizar em laboratório o que a natureza produz em seu curso normal, custa caro não apenas no bolso, mas também pode produzir efeitos indesejados e de risco para a saúde humana e para os recursos naturais. Isto instiga a sociedade a mobilizar-se e pressionar a intervenção do Estado por meio de medidas de controle e fiscalização, a exemplo dos organismos geneticamente modificados e a criação da lei de Biossegurança - Lei no 11.105, de 24.03.2005 (BRASIL, 2008).

Esta dinâmica leva, por sua vez, as indústrias e as instituições de pesquisa, de certa forma, a intensificarem suas pesquisas de modo a obter resultados que se aproximem cada vez mais da realidade da natureza, objetivando diminuir os riscos ou, ainda, que potencialize a capacidade produtiva dos produtos dela advindos, num processo constante que atravessa décadas. 
"Cinco variedades de milho adaptadas aos aspectos climáticos e às características do solo da região que elevam a produtividade dos sistemas de produção" (EMBRAPA, 2006:136).

"O macho terminal Embrapa MS60 é um reprodutor híbrido recomendado para o cruzamento com fêmeas híbridas ou F1, produzidas a partir de linhas fêmeas das raças brancas Landrace (LD) e Large White (LW) de alta prolificidade. Essa combinação genética garante, ao produto final destinado ao abate, excelente desempenho e carcaça com destacado índice de bonificação na tipificação" (EMBRAPA, 2006:280).

Os protagonistas envolvidos com a ciência e tecnologia, na maioria das vezes, não trabalham de forma isolada, geralmente constituem-se em rede e de forma cooperada para melhor consolidação dos resultados. Nesse sentido, o papel do Estado, entre outros, é viabilizar os procedimentos burocráticos.

“Em novembro de 2005, o Canadá assinou um acordo de
cooperação científica e tecnológica com a Índia e, em janeiro deste
ano, firmou uma parceria semelhante com a China. Depois de
estreitar os laços na área de pesquisa e desenvolvimento com as
duas economias emergentes... Agora outra vedete do clube dos
ascendentes, o Brasil. (...) os governos de ambos os países
assinaram um protocolo de intenções para pavimentar o caminho
rumo a uma parceria bilateral na área de ciência, tecnologia e
inovação" (FAPESP, 2007:25).

A história nos mostra o papel relevante que a ciência e a inovação tecnológica tiveram para a modernização da agricultura; no entanto, também nos revela seus pontos de acesso precários dos grupos distintos de produtores, especialmente os agricultores familiares. A cooperação, dependendo da forma como é estabelecida, pode constituir-se numa alternativa a este modelo de desenvolvimento que submeteu a agricultura e agropecuária a altos padrões de produtividade, negligenciando os aspectos sócio-ambientais.

Muitas têm sido as discussões no meio acadêmico, bem como em outros grupos sociais interessados na temática da agricultura familiar, sobre os limites 
deste modelo para a viabilidade da produção da unidade familiar, e buscam alternativas para superar os problemas encontrados por este grupo social (BADALOTTI e REIS, 2005).

A agricultura familiar tem grande expressão econômica para o Produto Interno Bruto - PIB, do País. Representou, no período de 1995 a 2005, dez por cento de toda riqueza produzida no Brasil (Guilhoto et al, 2007); no entanto, ainda não consegue usufruir, consubstancialmente, das suas benesses. Isto revela um desafio para o Estado no que se refere à inclusão efetiva da agricultura familiar na economia brasileira.

Políticas como a do PRONAF, demonstra certo esforço por parte do Estado neste sentido. Entretanto, ainda há um longo caminho a percorrer. Muitos dos entraves ao sucesso de alguma políticas, encontra-se na fragilidade da confiança da sociedade do seu potencial de desenvolvimento (ABRAMOVAY, 2001).

$\mathrm{Na}$ expectativa de apresentar alternativas tecnológicas à agricultura familiar, a Embrapa, recentemente, reuniu em uma publicação na qual traz a síntese do esforço da instituição pública de pesquisa agropecuária no desenvolvimento de um conjunto de tecnologias aplicáveis a este segmento produtivo (EMBRAPA, 2006).

A síntese desse capítulo nos revela que o processo de modernização da agricultura, promovido e estimulado pelo Estado, ocorreu de forma desigual, principalmente entre os grupos de produtores, especificamente da agricultura familiar, e baseou-se no padrão agrícola voltado para o aumento da produção e da produtividade com vistas à integração da agropecuária à indústria e ao mercado externo, orientando-se no sentido de favorecer os interesses do capital.

A modernização da agricultura alterou as formas e organização do trabalho, bem como gerou efeitos deletérios ao meio ambiente. A constituição de redes sociotécnicas pode contribuir para uma maior interação e articulação entre as instituições em busca de soluções que minimizem tais efeitos, com vistas a sustentabilidade dos processos produtivos e ambientais.

O papel da ciência e da inovação tecnológica nesse processo foi de singular importância, tendo como ator principal, além do Estado como indutor delas, os institutos de pesquisa, cuja reestruturação se fez necessária ao atendimento a uma maior eficiência à produção agrícola. A história da implantação de um deles é o assunto a ser tratado a seguir. 


\section{CAPÍTULO 2}

\section{A EMBRAPA PECUÁRIA SUDESTE: UMA INSTITUIÇÃO DA MODERNIDADE}

A Embrapa surgiu a partir do projeto de modernização da agricultura brasileira, proposto pelo Estado.

Antes de posicionar a Embrapa Pecuária Sudeste no contexto brasileiro, será necessário discorrer, sucintamente, sobre as condições em que a mesma foi construída no âmbito da sociedade moderna e suas práticas no meio rural, isto é, com o surgimento da denominada Revolução Verde.

\subsection{Contexto do novo desenho institucional para a agricultura brasileira: a Revolução Verde}

Para melhor compreender o cenário agrícola no qual a Embrapa foi criada, ou seja, na década de setenta, convém contextualizar o Brasil no que se refere ao padrão agrário da época. Este estava relacionado com o padrão da produção em grande escala.

No final da década de 1950, após um período de intenso crescimento industrial e de urbanização, marcado por desequilíbrios e pressões inflacionárias, o qual sinalizava uma economia em crise e com tendência ao declínio, uma discussão em torno da concentração da estrutura agrária, atribuía a esta a responsabilidade pela não manutenção do crescimento econômico (VEIGA et al, 2003b).

Nas décadas que se seguiram, ou seja, sessenta e mais fortemente na década de setenta, a evolução da agricultura brasileira passa por um processo radical de transformação, chamado modernização da agricultura. Este, marcado por um padrão de distribuição latifundiária, altamente concentrado, bem como “(...) pela enorme ampliação do crédito rural subsidiado; pela internacionalização do pacote tecnológico da Revolução Verde; e pela melhoria dos preços internacionais para produtos agrícolas" (VEIGA et al, 2003b:306).

Vale salientar, que no Brasil, o processo de modernização da agricultura ocorreu num dos períodos mais conturbados da nossa história, ou seja, no contexto da ditadura militar. O caráter intervencionista e centralizador do Estado, produziu leis como, por exemplo, o "Estatuto da Terra" que primava, entre outras coisas, pelo 
aumento da produção e da produtividade, significando uma vitória do regime militar (SILVA, 1999c).

Para a autora, esse foi um processo que gerou conseqüências danosas para os pequenos produtores; entre elas, a expropriação das suas terras o que produziu uma massa enorme de "sem rumo" em busca de trabalho para sua manutenção e, até mesmo para sobrevivência. Faz, ainda, uma revelação: "No período de 19601980, foram expulsos 2,5 milhões de pessoas do campo paulista" (SILVA, 1999c:63). Ela chama tal fenômeno de modernização trágica (grifo da autora), pois tal processo se deu na fragilidade do diálogo, ou, talvez, na completa ausência dele. Ele foi marcado pela violência, perseguição de camponeses e a desarticulação, ou mesmo, a destruição dos movimentos sociais que lutavam pela reforma agrária.

A Revolução Verde não é algo que ocorre endogenamente ao Brasil, ao contrário, ela é um fenômeno que acontece em vários países, como o México e a Índia. O processo e os primeiros experimentos foram realizados em centros de pesquisas nos Estados Unidos, tendo como finalidade a suposta aplicação universal, com vistas a amenizar a fome no mundo. Acreditava-se, naquele momento, que o simples fato de aumentar a oferta de alimentos resolveria a problemática da fome no planeta (FREITAS, 2007).

A chamada Revolução Verde, corresponde à forma de promover um significativo aumento na produção, em especial, de cereais e grãos básicos à alimentação, como o arroz, o milho e o trigo. Esse progresso produtivo tinha como base a necessidade de emprego de insumos agrícolas, quais sejam, fertilizantes, herbicidas e inseticidas, além da irrigação. Os resultados deste novo modelo agrícola, aconteceram de forma diferenciada entre os países que o incorporá-lo (NETO, 1999).

No Brasil, no início dos anos setenta, o que se discursava era da necessidade da modernização do processo produtivo no campo, a fim de atender às novas exigências da economia e da sociedade como um todo. Assim, na forma de "pacote tecnológico", o padrão técnico da "Revolução Verde" foi intensificado no Brasil, constituindo-se na adoção de práticas agrícolas baseadas no emprego de novas tecnologias e crédito subsidiado (FLORES, 1991).

Para Aguiar (1986:42), "pacote tecnológico" é definido como “(...) o conjunto de técnicas, práticas e procedimentos agronômicos que se articulam entre si e que são empregados indivisivelmente numa lavoura ou criação, segundo padrões 
estabelecidos pela pesquisa". O autor o compara ainda a uma "linha de montagem" que, como qualquer sistema, tem seus processos interligados e interdependentes. Por conseguinte, o sucesso ou não da atividade produtiva está condicionado ao uso completo do pacote.

Seguindo o raciocínio, significa dizer que, durante o processo produtivo, as suas diferentes fases exigem determinadas tecnologias ou componentes anteriores, como, por exemplo, máquinas e equipamentos para os serviços de preparo do solo, bem como precisará de determinadas tecnologias ou componentes posteriores como a adubação e o combate a pragas. Desta forma, para obter-se os resultados prometidos pelo pacote, é necessário que a "engrenagem" funcione completa.

No caso do pacote tecnológico atribuído à "Revolução Verde", a engrenagem exigia a adoção de práticas agrícolas voltadas para o emprego de novas tecnologias e práticas agrícolas baseadas na intensa mecanização do processo produtivo, cujos resultados seriam a implementação, intensificação e o aumento da produtividade agrícola para o abastecimento interno e, principalmente, para exportação (SILVA, 1981).

O novo padrão tecnológico produziu significativas modificações nas áreas cultivadas dos principais produtos agrícolas, ditos modernos (como a soja e a cana), às quais expandiram-se para outras áreas anteriormente ocupadas por produtos considerados tradicionais (arroz e feijão, por exemplo).

Essa mobilidade das culturas e dinâmica do uso da terra produziram efeitos danosos do ponto de vista da perda do vínculo com a terra para os pequenos produtores, pois estes, ao não se enquadrarem às novas práticas, ou melhor, à nova base tecnológica de produção, tiveram que se desfazer da sua propriedade e tornaram-se assalariados. Suas terras, por sua vez, foram incorporadas às áreas da agricultura moderna, favorecendo ainda mais a concentração fundiária e os grandes proprietários rurais.

“(...) o padrão tecnológico adotado na agricultura brasileira, ao mesmo tempo que representou uma potenciação da capacidade produtiva da terra e do trabalho, permitindo acréscimos sensíveis de produtividade, também significou uma proliferação do emprego sazonal. Do ponto de vista dos trabalhadores, isso significou 0 aumento do desemprego (ou subemprego) estacional" (KAGEYAMA, 1982:26). 
Cândido (1964), ao descrever a fala de um saudoso produtor, quando o mesmo referia-se à perda da posse da terra, diz: "Mas depois vieram os fazendeiros ricos e, como a caboclada era ignorante, foram comprando barato de uns, tomando à força de outros. Tinha gente que chegava e ia expulsando os 'cuitadinho' a pau e tiro" (CÂNDIDO, 1964:156).

É importante considerar que, boa parte daqueles que não adotaram essa nova tecnologia, foram separados dos seus meios de produção e tornaram-se ofertantes da sua força de trabalho.

Para Aguiar (1986:98), a modernização da agricultura caracteriza-se por dois fatores concomitantes: "modificações nas relações técnicas de produção, através da intensificação do uso de máquinas e insumos (...)" e o "aprofundamento das relações sociais capitalistas de produção (...)" por meio do assalariamento parcial e precário do produtor rural. Este fenômeno, continua o autor, é intensificado pelo "(...) aumento da sazonalidade e ao alargamento da monocultura em algumas áreas do país" (AGUIAR: 1986:111).

Diante da nova realidade, altera-se as relações de trabalho no campo, bem como o perfil da absorção de mão-de-obra no ciclo das principais culturas. No primeiro caso, ocorre a transformação dos antigos parceiros, colonos e moradores em trabalhadores volantes (AGUIAR, 1986). No segundo, tem-se, pela especialização das culturas, o aumento da sazonalidade da absorção da mão-deobra; quando pior, ela é poupadora de mão-de-obra: "Assim, ela será reduzida em algumas fases do calendário agrícola e repentinamente elevada em outras (...)" (SILVA, 1981:113).

A modernização da agricultura, promovida pela Revolução Verde, teve efeitos diretos no chamado êxodo rural contribuindo para a mudança na qualidade do processo de urbanização, bem como pelo assalariamento da força de trabalho agrícola. Outras consequências foram a homogeneização das práticas produtivas e do meio natural, o comprometimento da quantidade e qualidade dos cursos d'água, contaminação de alimentos e o empobrecimento da diversidade genética de plantas e animais (VEIGA et al, 2003b).

Na dinâmica dessa relação, muda também a configuração do território e as relações ocorridas no mesmo. A instalação dos fixos e fluxos novos, que desenha a produção de um novo lugar, também produz e determina seu significado, bem como caracteriza as mudanças no ambiente social. 
Houve, ainda, uma baixa reflexividade no que concerne à avaliação dos impactos ambientais das inovações no meio rural. Veiga (2003a), ao referir-se à utilização de fertilizantes químicos, considera: "Sem freios institucionais, os praguicistas e os fertilizantes químicos continuarão a ser utilizados até o limiar de sua rentabilidade, que costuma estar muito além do limiar de nocividade" (VEIGA, 2003a:201).

Nesse contexto, a ação do Estado foi propulsora de uma modernização que não se constituiu num processo simplesmente dado, mas, ao contrário, ele foi construído e porque não dizer induzido por meio dos seus decretos e atos que o regulamentou e "legitimou" a partir do regime de governo da época, ou seja, um regime autoritário (AGUIAR, 1986).

É no conteúdo do Programa Estratégico de Desenvolvimento - PED, no final da década de sessenta (1967-1969), que melhor se expressa a importância que esse programa de governo atribuiu ao progresso tecnológico. É nele, ainda, que se propõe, pela primeira vez, a adoção de uma política científica para o desenvolvimento tecnológico no país, sendo uma área, inclusive, vista como própria de atuação do Estado.

O padrão técnico é estimulado, não apenas por fatores endógenos, como os problemas relacionados à baixa produtividade dos produtos agrícolas ou outros fatores de ordem econômica, mas também por fatores exógenos de cunho subserviente ao capital estrangeiro como as multinacionais, expressos no uso de máquinas de maior potência, especialmente, destinadas às grandes explorações agrícolas e ainda, a adoção de adubos químicos e defensivos agrícolas (SILVA, 1981).

Na implantação, entretanto, do novo Plano de Metas e Bases para Ação de Governo (1970-1971), proposto pelo Estado, seu conteúdo pouco muda em relação ao anterior, reiterando a política modernizadora proposta pelo PED, sendo também favorável ao ingresso do capital estrangeiro (AGUIAR, 1986).

"Desenvolvimento tecnológico da agricultura, por meio de: programa de disseminação de insumos modernos, com redução ou eliminação de impostos sobre eles incidentes e consolidação dos esquemas de financiamento, fortalecimento da indústria nacional de fertilizantes e 
da indústria nacional de defensivos agrícolas; expansão do Plano Nacional de Mecanização Agrícola (...)" (BRASIL, 1970:57).

Seguindo, ainda, nos planos de governo, é no Primeiro Plano Nacional de Desenvolvimento - I PND (1972-1974) que a modernização tecnológica passa a significar um instrumento político e a necessidade de integrar o Brasil à economia mundial.

"Em consequência, principalmente, da aceleração do progresso tecnológico e gerencial, as empresas multinacionais passaram a assumir maior importância, aumentando mais rapidamente suas vendas no exterior do que no país de origem. Integrando-se na economia mundial, o Brasil objetiva crescer rapidamente" (BRASIL, 1971:33).

É possível supor, então, que instituições e organizações podem ser indutoras da adoção de determinado padrão tecnológico, bem como, outras, podem ser criadas para garantir sua viabilidade. Desta forma, o Estado, no aspecto da modernização da agricultura, promoveu as condições otimizadoras a partir da criação do sistema nacional de pesquisa agropecuária, sistema brasileiro de assistência técnica e extensão rural e o sistema nacional de crédito.

Talvez, ainda, em função disso, tenha ocorrido de maneira crescente a modernização do Estado a partir, não somente, da criação de algumas estatais, bem como a transformação de certas autarquias como, por exemplo, o Banco Nacional de Desenvolvimento Econômico e Social - BNDES, em 1971, em empresas de administração indireta (BNDES, 2007), cujo propósito era dar agilidade e flexibilidade à máquina pública.

Aguiar (1986:91) pontua: “(..) a maciça criação de empresas estatais nessa fase atendia à necessidade de aprofundar, em bases empresariais, a relação do Estado com as empresas multinacionais".

Expor este cenário torna-se importante para que se possa entender o papel do Estado como indutor e executor de políticas públicas, muitas vezes voltadas para atender segmentos já, historicamente, beneficiados, como o capital. Embora seu discurso tenha a abrangência da melhoria das condições da sociedade, elas, 
contudo, só ampliam as desigualdades de oportunidades e a concentração de riquezas.

Retomando a questão do pacote tecnológico da Revolução Verde, este padrão produtivo, no entanto, passou a apresentar limites de crescimento a partir da década de oitenta, com a diminuição do ritmo de inovações tecnológicas (ALBERGONI, 2007).

No ambiente da modernidade, quando um modelo começa a apresentar sinais de esgotamento da sua eficiência, é de se esperar que as organizações e instituições busquem adotar novas estratégias que as mantenham competitivas no mercado, às quais podem vir a ser o uso de novas tecnologias que provoquem uma mudança de longo alcance e que impliquem, por exemplo, em um novo "padrão" a ser seguido.

Desta forma, a partir da década de oitenta, o modelo apresentado pela Revolução Verde, passou a demonstrar os sinais de ineficiência, não apenas no aspecto da produção mas também para indicadores sócio-ambientais, evidenciados na forma de problemas relacionados ao meio ambiente como a salinização, erosão do solo, perda de biodiversidade, dependência excessiva de combustíveis fósseis e poluição causada pelos fertilizantes, pesticidas e herbicidas.

No contexto econômico, observou-se declínio e estagnação da produtividade, solo esgotado e vulnerabilidade das culturas e, sob o aspecto social, produziu-se o endividamento e a exclusão de pequenos produtores (ALBERGONI, 2007).

Muitos podem ser os efeitos produzidos por modelos que pretendem resolver os problemas econômicos de uma sociedade, seja moderna ou tradicional, mas nada pode ser comparado àqueles causados ao tecido social. A Revolução Verde levou comunidades rurais ao declínio e promoveu a migração do campo para a cidade, produzindo bairros marginalizados nos grandes centros das cidades e 0 aumento do desemprego (ROMEIRO, 1998).

Os efeitos produzidos pela política de modernização da agricultura levaram à instabilidade e insegurança da base mais elementar de uma sociedade: a família, a qual o Estado deveria cuidar e, neste caso, as famílias rurais. Estas não apenas tiveram perdas materiais, mas também a posse da terra, da qual tiravam seu sustento, levando-as a aventurar-se em ambientes hostis e desconhecidos como as cidades. Tal realidade, submeteu estas famílias a condições de vida sub-humanas, levando-as a ofertar sua força de trabalho a atividades nas quais não estavam 
acostumados a labutar, como a construção civil. Fatores referentes a sua subjetividade também foram afetados, como àqueles ligadas à afetividade, relações de sociabilidade, manifestações culturais que lhes constituíam a identidade e seus significados (HENK, 1990).

O valor simbólico, exposto acima, pode ser melhor traduzido, mais uma vez, na observação de Cândido (1964), quando expressa a fala do caipira:

"(...) o "tempo de dante", ou "dos antigos”, era o próprio reino da
fartura", “(...) Um dedal cheio de arroz dava produção abundante,
pois era imensa a força da terra. As colheitas era tão grande que
nem se colhia tudo (...)", "Todos se ajudavam por amor de Deus e
ninguém passava apêrto (...)" (CANDIDO,1964:155).

Não se pretende, todavia, com o exposto acima, pregar o arcaísmo; contudo, políticas públicas e, por que não dizer os programas de pesquisa para a agricultura, são importantes na determinação e melhoria dos índices sócio-econômicos do país, mas é importante direcionar esforços para assegurar que os impactos por este ou aquele programa venham ser administrados de forma que os riscos sejam minimizados. Veiga (2003a:200) sintetiza bem isso: “(..) a história também nos ensina que grandes sucessos sempre se transformam em excessos quando não são devidamente controlados".

Neste contexto, instituições oficiais de pesquisa e outros organismos nãogovernamentais, buscaram formas de superar ou minimizar as práticas nocivas do padrão vigente. Debateu-se acerca da necessidade de um novo padrão tecnológico, ecológica e economicamente sustentável, diferente daquele baseado no uso intensivo de insumos químicos. Alternativas como agricultura orgânica, biodinâmica ou mesmo agroecologia (VEIGA, 2003a).

Assim, é na reflexividade das ações e na circulação do conhecimento que novas possibilidades podem surgir e mudar o cenário, não apenas agrícola, mas do desenvolvimento sustentável brasileiro.

"Se ha establecido un ciclo virtuoso: los nuevos conocimientos, traducidos como informaciones y tecnologías, se incorporan a los sistemas productivos agropecuario y forestal y producen más 
informaciones (respuestas y cuestionamientos) que propiciaron la producción de nuevos conocimientos" (EMBRAPA, 2006a:14).

Todavia, a questão é, dada a característica de descontinuidade da modernidade - conforme dito por Giddens (1991), expressa pelo ritmo e a urgência em que as coisas precisam acontecer, até que ponto, o debate produzido pelas instituições e organizações gera um grau de reflexividade, cujas propostas permitirão novos padrões que não venham promover, quando não, intensificar, os riscos e ameaças colocando, mais uma vez, a humanidade e o meio ambiente em situação de vulnerabilidade e insegurança?

\subsection{Implantação da Embrapa: origem e caracterização da instituição}

No início da década de setenta, a agricultura brasileira apresentava um modelo de política voltado para a agricultura de exportação. Durante este período, observouse uma mudança na composição da área cultivada e da produção agrícola, no que se refere às lavouras de exportação e de abastecimento interno (AGUIAR, 1986).

$\mathrm{Na}$ época, o Brasil, inquestionavelmente, precisava não apenas desenvolver a agricultura, devido à necessidade de atender à demanda progressiva de alimentos, mas também esperava “(...) equilibrar sua balança de pagamentos, através do crescimento das exportações de grãos, já que a produção de commoditties agrícolas naquela época era limitada a café, açúcar, cacau e algodão" (CABRAL, 2005:11).

Assim, a fundação de uma empresa pública de pesquisa no tema da agropecuária, não acontece por acaso. No início dos anos setenta, o país vivia o auge da Revolução Verde e ainda mantinha uma política de substituição de importações; esta, no entanto, não estava livre de críticas; como afirma Tavares (1983:167): "É indiscutível que a crise econômica pela qual a economia brasileira passou, em meados da década de sessenta, esteve estritamente relacionada, a nível estrutural, com o esgotamento do dinamismo da industrialização baseada na substituição de importações".

É exatamente neste período, quando o padrão tecnológico, trazido pela Revolução Verde, apresentava a necessidade de implementação, especialmente ao desenvolvimento e aprimoramento da pesquisa no país, que surge a proposta de criação de “(...) um novo instrumento operativo para a pesquisa agropecuária 
nacional, que fosse a um só tempo ágil, dinâmico, flexível, suficientemente capaz de responder às necessidades do desenvolvimento do país." (CABRAL, 2005:26). Bem como, “(...) fosse um instrumento de justiça e progresso social” (EMBRAPA, 2002:11).

A agricultura nacional precisava de novo fôlego e de uma nova empresa que agregasse as instituições de pesquisa já existentes no país, obtendo uma nova condição jurídica que the desse agilidade e dinamicidade, a fim de gerar conhecimento e novas tecnologias para aumentar a produção interna de alimentos e ajustar as contas com a balança comercial.

Neste cenário, o Estado-nação centralizador, assume seu papel de controlador, coordenador, legislador e executor de normas e regras para uma nova política de pesquisa agropecuária nacional, bem como a mudança de sua estrutura. "A principal alternativa é criação de uma empresa pública, de acordo com a legislação em vigor, como órgão vinculado ao Ministério da Agricultura para promover e executar atividades de pesquisa agropecuária" (EMBRAPA, 2002:17).

Estas, entre outras, deveriam estar ajustadas “(...) aos objetivos e metas centrais do Governo, previsto no Plano de Desenvolvimento Econômico e Social e, em forma particular, às prioridades da política agrícola" (CABRAL, 2005:45).

Conforme foi dito anteriormente, muitas instituições e organizações emergem ou são criadas com o intuito de atender demandas que são produzidas a partir das relações econômicas, políticas e sociais, cujo papel do Estado, como interventor e promotor, torna-se essencial para viabilizá-las.

À época do lançamento do I PND (1972-1974), um outro instrumento político foi criado, o primeiro Plano Básico de Desenvolvimento Científico e Tecnológico - I PBDCT, no qual destacava-se como principal projeto para o setor agrícola, a implantação da Empresa Brasileira de Pesquisa Agropecuária - EMBRAPA (AGUIAR, 1986).

"Essa empresa, que substituirá o atual Departamento Nacional de Pesquisa Agropecuária, órgão de administração direta, atuará (...) em forma tal que possibilite a promoção e execução de planos, programas e projetos de pesquisa que criem inovações tecnológicas destinadas a apoiar o Governo e a atividade privada na consecução das suas metas de desenvolvimento no setor agricultura" (BRASIL, 1973:81). 
Desta forma, em 26 de abril de 1973, foi criada a EMBRAPA, cuja missão era “(...) viabilizar a modernização e o crescimento da agropecuária, através da pesquisa tecnológica, da transferência do conhecimento ao produtor rural e da extensão das fronteiras agrícolas" (CABRAL, 2005:11).

A missão da nova empresa expressava, de forma clara, os objetivos propostos no projeto de política pública para o setor agropecuário do país, descrito anteriormente, em seus diferentes planos de desenvolvimento econômico.

As leis, decretos e procedimentos que deram origem à implantação da Embrapa enquanto empresa pública, a consolida como uma empresa da modernidade, uma vez que a mesma incorpora os padrões técnicos da época, com vistas ao aumento e intensificação da produtividade, em consonância com a sua missão, bem como com o modelo político proposto para a agricultura, no qual contemplava a adoção de novos procedimentos técnicos com vistas ao crescimento do setor e o abastecimento interno e, especialmente, para exportação.

A proposta de um novo projeto para a agricultura continuava a ser aquele que gerasse ações que viabilizassem o aumento da produtividade; afinal, a população e a urbanização continuavam a crescer e demandar uma oferta maior de produtos e alimentos a preços menores. Entretanto, algo se diferenciava: a preocupação e a atenção para os efeitos causados ao meio ambiente e a busca por fontes alternativas de energia se faziam prementes.

Outro fator importante relacionava-se ao conhecimento científico para apoiar o desenvolvimento agrícola. A pesquisa agrícola passou a ser vista, pelo Estado, como eficiente no caso de assegurar uma agricultura competitiva. Contudo, a estrutura de pesquisa no país era insuficiente para abarcar a agropecuária brasileira no que concerne ao contexto geográfico, produtivo e ambiental brasileiro (EMBRAPA, 2002).

A sustentabilidade social e ambiental, passa a fazer parte desta equação se subordinando à racionalidade do mercado.

Antes da criação da Embrapa, a pesquisa agropecuária, no Brasil, apresentava um modelo "difuso", no qual os projetos eram elaborados a partir da área de formação do pesquisador, dentro das diferentes disciplinas que compõem 0 conhecimento. Após a implantação da empresa, esse modelo torna-se "concentrado", ou seja, a pesquisa agropecuária passa a ser desenvolvida por produto dentro de uma perspectiva de "sistemas de produção". Isto é: 
“(..) para cada produto há um conjunto de tecnologias e procedimentos auxiliares que são recomendados para se atingir 0 resultado desejado de maior produtividade física. Assim, para cada produto pesquisado a Empresa procura apresentar diferentes alternativas de produção, que devem ser indicadas para as diferentes regiões e tipos de produtores" (KAGEYAMA et al, 1982:29).

E ainda, os projetos de pesquisa passaram a buscar soluções para questões práticas (pesquisa aplicada), cujo esforço do conhecimento desenvolvido teve seu foco no produto, tema ou ecorregião (EMBRAPA, 2002).

O modelo de pesquisa apresentado pela Embrapa teve seu foco no produto, pautado no exemplo das grandes instituições internacionais de pesquisa, e que primavam pela seleção de novas variedades. O modelo recebeu críticas como sendo incapaz de resolver o problema do empobrecimento de produtores rurais, em função do alto custo do pacote tecnológico (ROMEIRO, 1998).

O ano de 1973 foi promissor para o Brasil, que obteve o auge do milagre econômico. Entretanto, na atividade agrícola, a tarefa era mais difícil; precisava ampliar suas bases tecnológicas, reciclar aquelas advindas de uma proposta externa e reaproveitá-la dentro de uma realidade nacional. Faltava mão-de-obra especializada para traçar o caminho do desenvolvimento agrícola pretendido pelo Ministério da Agricultura (EMBRAPA, 2002a).

Diante do desafio e da necessidade urgente de formar especialistas, quando da criação da empresa, foi considerado como ponto relevante incluir, entre outros, como principal diretriz, a formação de mão-de-obra qualificada, uma equipe que garantisse a competência técnica para o exercício da pesquisa agropecuária.

“(..) a Empresa adotou, de imediato, um programa de curto e longo prazos no sentido de mobilizar todo o potencial científico do País que possa ser aproveitado como corpo técnico, competente e dedicado, para o difícil exercício da função de pesquisador" (EMBRAPA, 2002:26).

A estrutura da pesquisa agropecuária brasileira, ligada ao Ministério da Agricultura, era coordenada pelo Departamento Nacional de Pesquisa e 
Experimentação Agropecuária (DNPEA), que congregava todos os organismos de pesquisa existentes até então (EMBRAPA, 2002).

Com a instalação da Embrapa, o DNPEA, embora elementos da sua estrutura tenham sido incorporados à nova empresa, foi extinto no último dia do ano de 1973 (EMBRAPA, 2002).

Desta forma, a Embrapa assume a responsabilidade pela estrutura física e passa a administrar todo o sistema de pesquisa agropecuária, em nível de Governo Federal. A nova empresa herda, ainda, a estrutura do DNPEA composta por bases físicas e de recursos humanos.

"A Embrapa foi criada com a finalidade de centralizar a pesquisa agropecuária em todo território nacional. Ela significou uma profunda mudança na forma do governo federal tratar a pesquisa" (KAGEYAMA et al, 1982:28).

Nesta perspectiva, criava-se ainda o Sistema Nacional de Pesquisa Agropecuária (SNPA), cujo objetivo era articular e integrar as diferentes entidades de pesquisa agrícola (CABRAL, 2005:82).

A nova estrutura de pesquisa passa a ser da seguinte forma (EMBRAPA, 2002:21):

- Centros nacionais por produtos;

- Centros regionais (Semi-Árido, Trópico Úmido e Cerrados);

- As Unidades de Execução de Pesquisa de âmbito Estadual ou Territorial - UEPAES's e UEPAT's;

- Empresas estaduais, que deveriam substituir, paulatinamente, as UEPAE's E UEPAT's.

As UEPAES's e UEPAT's são estruturas pertencentes ao antigo DNPEA, são unidades descentralizadas, responsáveis pela execução de pesquisa, ou seja, são estações experimentais e deveriam constituir pré-estrutura para as empresas estaduais.

Definir a estrutura apenas não era o suficiente. Fazia-se necessário criar instrumentos que dessem dinamicidade ao conjunto, ou melhor, explicar seu funcionamento, elaborar normas para o desenvolvimento da pesquisa. "Em agosto 
de 1974, surge o Guia de Planejamento - uma verdadeira bíblia de conduta para a nova empresa" (EMBRAPA, 2002:23).

Ainda em 1974, foi criado o Programa Nacional de Pesquisa Agropecuária PRONAPA, no qual deveria constar as orientações para a distribuição dos recursos de pesquisa agropecuária. Representava a sistemática de planejamento e contemplava as atividades, quer das unidades da Embrapa, quer dos sistemas estaduais de pesquisa (EMBRAPA, 2002:24).

Com a Constituição de 1988, o país apresenta nova organização, mudanças políticas e a necessidade, segundo alguns críticos, de enxugar a estrutura vigente do setor. Contudo, o que ocorre, é apenas uma mudança de nome, ou seja, as UEPAES's, gradativamente, ganham status de Centros de Pesquisa Ecorregionais" (EMBRAPA, 2002:133).

Durante as décadas de setenta e oitenta, são inegáveis os ganhos obtidos para a agropecuária brasileira em termos de expansão agrícola, intensificação da produção e aumento da produtividade como resultados e ganhos tecnológicos já incorporados pelo setor. Estes resultados têm expressão, por exemplo, na introdução do plantio de grãos na região dos Cerrados, o desenvolvimento de novas cultivares de arroz, soja, cana, feijão e milho e a melhoria da produção de leite e carne (FLORES, 1991).

Diante dos impactos positivos apresentados pelas tecnologias desenvolvidas pela Embrapa, em termos de produtividade e aceitação pelos produtores, é possível supor que a mesma conseguiu atingir os objetivos propostos em sua missão. Contudo, tais conquistas não se refletem em melhoria das condições de vida para as populações rurais que continuam à margem dos progressos alcançados, sobretudo à produção de base familiar.

Kageyama et al (1982:27), considera que: "O planejamento e a programação dos setores institucionais ligados à pesquisa e extensão podem se efetuar no sentido de favorecer determinados grupos".

Desta forma, é necessário manter-se vigilante e prosseguir com as discussões sobre as alternativas viáveis à inclusão efetiva dos indivíduos, bem como sobre os efeitos ou consequências que este ou aquele padrão tecnológico podem trazer para aquele segmento que se pretende atingir ou, ainda, para a própria sociedade e para o meio ambiente. 
Nesse sentido, Alves (1979) faz uma reflexão sobre a necessidade de que as instituições de pesquisa atentem para ações que intensifiquem os estudos sobre 0 uso do controle biológico no combate a pragas, doenças e plantas invasoras, tendo em vista à redução do uso de agroquímicos; a proteção do meio ambiente e a economia de divisas; técnicas de uso consorciado que beneficiem o pequeno produtor e, especialmente, estudos que demonstrem os efeitos da modernização da agricultura sobre os trabalhadores rurais e pequenos agricultores.

Assim, atendendo a uma reorientação dos objetivos da Embrapa, foram criadas novas unidades de pesquisa bem como novos programas com finalidades específicas, visando suprir as atuais carências tecnológicas que, de um lado, minimizassem os efeitos danosos provocados por práticas inadequadas de produção agrícola, do ponto de vista da sustentabilidade social e ambiental e, de outro, se dedicasse à produção familiar.

No primeiro caso:

\begin{abstract}
"A reorientação dos objetivos da EMBRAPA implicou na necessidade de mudança na ênfase em linhas de pesquisa que efetivassem os princípios de independência tecnológica, de redobrado esforço na produção alimentar, de preservação do meio ambiente e conservação dos recursos naturais e na busca de novas alternativas tecnológicas que privilegiem os processos biológicos" (EMBRAPA, 1986:20).
\end{abstract}

Em novembro de 1985, foi inaugurado o "Centro Nacional de Pesquisa para Defesa da Agricultura". Este fato, traduziu a responsabilidade do sistema de pesquisa, para com as práticas do agricultor e seus desdobramentos no meio ambiente diante dos riscos reais, como o uso indiscriminado de agrotóxicos no país. Seu objetivo era:

“(...) desenvolver pesquisas na área de controle biológico e integrado de pragas, moléstias e doenças de plantas, métodos de proteção ao meio ambiente, avaliação de produtos para emprego na agricultura, bem como a identificação de resíduos prejudiciais à saúde nos alimentos destinados ao consumo humano" (EMBRAPA, 1986:20). 
Em relação à pequena produção, em 1986, a Embrapa passa a apoiar a execução das ações de política pública voltadas para a reforma agrária em parceria com outras instituições ligadas a este segmento:

“A EMBRAPA apoiará, em 1986, a execução do Plano Nacional e dos Planos Regionais de Reforma Agrária, em estreita colaboração com o INCRA, a EMBRATER e a EMATER de cada Estado, mediante alocação de recursos humanos e materiais para a geração de tecnologia agropecuária específica e apropriada às áreas selecionadas para assentamento" (EMBRAPA, 1986:33).

Recentemente, de acordo com o BCA 05/2004, Resolução nํ 01, foi aprovado o programa institucional Macro Programa 6, voltado a projetos que contemplem 0 "Apoio ao Desenvolvimento da Agricultura Familiar e à Sustentabilidade do Meio Rural” (EMBRAPA, 2004b), considerado estratégico para o País.

A década de noventa trouxe novos temas à agenda de pesquisa, bem como requereu novo esforço das instituições de pesquisa agropecuária, a Embrapa soube inserir-se com um discurso institucional que dava provas de aceitação do desafio dos tempos.

Para Flores (1991), somente as instituições capazes de perceber tais mudanças serão legitimadas pela sociedade.

Assim, já na década de oitenta, a Embrapa se antecipou e buscou se ajustar às novas demandas e exigências promovidas por esse novo cenário.

Não apenas as estruturas se estabelecem, mas é necessário produzir também novos conhecimentos peritos, de uma competência técnica tal que o leigo sequer pense em duvidar da sua eficiência e mantenha, assim, inabalável a confiança nas instituições que os representam.

Eficiência aqui se traduz pelas condições de apresentar maior potencial de impactos positivos em termos distributivos de ganhos de capital e da melhoria das condições de vida (saúde, alimentação, emprego, moradia, transporte e educação) para o conjunto dos produtores, comparado ao padrão anterior. Produz-se, ainda, na reflexividade, ou seja: “(...) significa que as práticas sociais modernas são enfocadas, organizadas e transformadas à luz do conhecimento constantemente renovado sobre estas próprias práticas" (SILVA, 2006:4). 
O conhecimento científico, neste caso, não significa o estar certo, mas a modernidade produz uma dinâmica sobre ele mesmo do auto-conhecimento sistemático, o qual produzirá novas "verdades". Giddens (1991), explica:

"A reflexividade da vida social moderna consiste no fato de que as práticas sociais são constantemente examinadas e reformadas à luz de informação renovada sobre estas próprias práticas, alterando assim constitutivamente seu caráter" (GIDDENS, 1991:45).

A inovação tecnológica deve ser capaz de, permanentemente, atentar para os limites e superá-los diante dos novos contextos que ditarão o que deve ser os alimentos nutricionalmente recomendáveis, produção geradora de renda, com cuidados ao meio ambiente, uso racional das fontes de energia etc..

Ademais, como Giddens (1991:38), no ambiente da modernidade, “(...) a confiança pressupõe consciência das circunstâncias de risco (...)", o que implica que a descontinuidade das técnicas, seja para reduzir a vulnerabilidade, seja para controle dos fatores de ameaças, deva ser constante.

Com o desenvolvimento das instituições sociais modernas, e os desafios tecnológicos, a busca por sistemas e processos que assegurem a confiança e minimizem os riscos, ou seja, um equilíbrio mínimo entre segurança e perigo, tornouse indispensável. O conhecimento reflexivo desestabiliza a relação entre peritos e leigos dado os efeitos observáveis nas experiências do cotidiano, expressas na sensação de insegurança, ansiedade e perigos. Assim, para reequilibrar esta relação, se exigirá do especialista uma contínua busca pelo autoconhecimento sistemático.

O saber especializado pressupõe, contudo, o monopólio da verdade acerca de uma dada dimensão da realidade de um conhecimento que só um pequeno grupo possui, o que o leva a dominar os demais, sobretudo se investidos do poder que as frações do Estado lhes investe.

No que concerne o conhecimento em si, a ciência proporciona aos técnicos perscutar um universo de possibilidades de mudanças do contexto produtivo agropastoril como nunca dantes foi possível. Projetos que envolveram organismos geneticamente modificados, a clonagem animal e o genoma (Cabral, 2005), são expressão disto. 
Santos (1992), chama atenção sobre o caráter tendencioso de como as demandas são produzidas no cenário da modernidade, obedecendo a uma dinâmica que parte de centros que as definem, priorizam e as localizam no espaço globalizado:

“Em cada período, o sistema procura impor modernizações características, operação que procede do centro para a periferia. Não se trata de uma operação ao acaso. Os espaços atingidos são aqueles que respondem, em um momento dado, às necessidades de crescimento ou de funcionamento do sistema, em relação ao seu centro" (SANTOS, 1992:31).

E exemplifica: “(...) não se poderia falar da existência de uma agricultura que requeira fertilizantes químicos antes que a indústria química tivesse se desenvolvido ou se estabelecido em algum ponto do globo" (SANTOS, 1992:31).

Novos tempos, novas oportunidades, novo contexto; tudo dinâmica da própria modernidade. Mas, alguns aspectos são mais perenes, quando se refere à incansável busca pelo equilíbrio e formas mais assertivas de conduzir a agricultura brasileira, a partir de um modelo mais sustentável. Nada tem a ver com um novo modelo em si, mas em novas práticas que envolvam o diálogo entre os atores que fazem o setor agrícola.

Atualmente, a Embrapa, a partir das suas publicações e discussões com a sociedade, tem buscado, no conjunto de suas ações, promover um diálogo dentro de uma visão contextualizada das diferentes realidades da agricultura brasileira:

“(..) um enfoque sistêmico que valorize o contexto. Essa visão holística - contextual - estimula, por exemplo, a multi, inter e transdisciplinaridade, o diálogo de saberes entre o conhecimento científico e o conhecimento tácito local (...)" (EMBRAPA, 2006b: 30).

"Mas o compromisso institucional da Embrapa é criar espaços de interação social para que os atores co-responsáveis pela relevância e pela governança da agricultura brasileira, em geral, e da agricultura familiar, em particular, possam influenciar o desenvolvimento rural que mais interessa à sociedade" (EMBRAPA, 2006b:27). 
E propõe, a partir desta nova postura, mudanças da dinâmica de construção das relações de negociação em busca do êxito:

\begin{abstract}
"Será imprescindível um conjunto de inovações institucionais complementares que estabeleçam nova coerência para o desenvolvimento rural e agrícola. Isso implica a construção de outras regras, papéis e arranjos institucionais comprometidos com uma maior relevância e melhor governança da agricultura" (EMBRAPA, 2006b:31).
\end{abstract}

Como o tema da pecuária bovina de leite será tratado nesse contexto, a partir da instituição da Unidade Embrapa Pecuária Sudeste, é o que veremos a seguir.

\title{
2.3. A Embrapa Pecuária Sudeste: missão institucional e estratégias
}

Boa parte das instalações que fazem parte da unidade, existe desde antes de 1935, e a área era uma fazenda da época da escravidão. Seu proprietário a perdeu em dívidas junto ao Banco do Brasil; este, a repassou ao Ministério da Agricultura. Assim, a fazenda passou a fazer parte do programa de pesquisa daquele Ministério, sendo implantada uma Estação Experimental de Criação Animal, cujas atividades de pesquisa, na época, estavam direcionadas para a adaptação e geração de tecnologias, visando sistemas de produção de carne e leite em bovino, a melhoria da eqüideocultura e, posteriormente, forrageiras (ALENCAR et al, 1988).

Uma das primeiras ações de pesquisa e a primeira tecnologia gerada na Estação, foi o desenvolvimento da raça bovina, genuinamente brasileira, chamada "Canchim" (EMBRAPA, 2000a:7).

Com o advento da Embrapa, a unidade de pesquisa passa a integrar o novo sistema de pesquisa agropecuária. Em agosto de 1975, nessa integração, ela passa a chamar Unidade de Execução de Pesquisa de âmbito Estadual - UEPAE de São Carlos (EMBRAPA, 2002).

Sua criação foi estimulada pela necessidade de promover o desenvolvimento da pecuária, pois, embora empresários do ramo buscassem minimizar os problemas da baixa produtividade com as tecnologias existentes, as mesmas ainda se mostravam insuficientes para promover o desenvolvimento da pecuária do Estado de São Paulo (RUZZA e BATISTA, 1986). 
A unidade só ganhou o status de centro de pesquisa, em primeiro de maio de 1993, quando passou a chamar-se Centro de Pesquisa de Pecuária do Sudeste CPPSE, cuja missão era "Gerar, adaptar e difundir conhecimentos e tecnologias adequadas ao desenvolvimento sustentável dos sistemas de produção de proteínas de origem animal da Região Sudeste", definida em seu I Plano Diretor da Unidade - I PDU (1993-1999) (EMBRAPA, 1993:19).

Em agosto de 1998, como estratégia de marketing, devido à necessidade de fortalecer o nome Embrapa nas manifestações de comunicação da Empresa, bem como padronizar a assinatura das Unidades Descentralizadas, foi recomendado, via Resolução Normativa $n^{\circ} 15 / 1998$, o uso obrigatório da assinatura síntese como Embrapa Pecuária Sudeste.

Um dos seus objetivos era a geração de informações que viessem a contribuir para a formulação de políticas agrícolas, de ciência e tecnologia e de desenvolvimento regional. Contudo, esta foi uma das lacunas identificadas nos objetivos da instituição, pois seus maiores beneficiários e usuários da pesquisa desenvolvida eram, na sua maioria, pesquisadores de outras instituições, agricultores e criadores (EMBRAPA, 1993).

Os produtos gerados pela pesquisa, até então, tinham aplicação na produção agropecuária, métodos de pesquisa, conhecimentos básicos para o avanço da ciência, variedade vegetal e raça animal. Embora houvesse a necessidade da geração de conhecimento que garantisse a sustentabilidade dos recursos naturais, os percentuais de aplicação da pesquisa nesta área decaíram na época (EMBRAPA, 1993).

A estratégia de ação adotada visava incentivar linhas de pesquisa em sistemas de produção de proteínas de origem animal, a partir de projetos interdisciplinares, cujas linhas de pesquisa, atenderam as oportunidades identificadas pelo setor produtivo, sendo elas (EMBRAPA, 1993:28):

“- alimentos alternativos e produtos biotecnológicos;

- análise e síntese de sistemas;

- bioclimatologia e comportamento animal;

- conservação e processamento de grãos e forragens; 
- estratégias de utilização de recursos genéticos animal e vegetal;

- exigências nutricionais de animais de alta produção;

- manejo de dejetos e reciclagem de nutrientes visando o equilíbrio ambiente-solo-planta-animal; e

- processos para melhoramento da qualidade dos produtos de origem animal".

Durante a década de noventa, a Unidade implementou suas estratégias de ação do seu I PDU com vistas a incentivar a execução de projetos interdisciplinares de Pesquisa e Desenvolvimento (P\&D). Em 2000, é lançado o II PDU (2000-2003), cuja missão era "Viabilizar soluções tecnológicas competitivas para o desenvolvimento sustentável do agronegócio da bovinocultura de corte e de leite da região Sudeste do País, em benefício da sociedade” (EMBRAPA, 2000:26).

O II PDU traz, então, o foco no agronegócio - sob o discurso de que "(...) para serem competitivos nos mercados interno e externo, os produtores necessitam de tecnologias, conhecimentos, produtos e serviços que viabilizem o agronegócio" (EMBRAPA, 2000:8) e, ainda, que se traduza em benefício para sociedade.

Além disso, um novo paradigma é apresentado à instituição de pesquisa, pois as novas demandas dos produtores são por pesquisas que envolvam a avaliação biológica e econômica. Este fato, exigirá um realinhamento das estratégias para as ações de P\&D (EMBRAPA, 2000).

Este realinhamento está expresso em seus objetivos, descritos como (EMBRAPA, 2000:28):

- viabilizar soluções tecnológicas para o desenvolvimento sustentável do agronegócio da bovinocultura na região Sudeste;

- viabilizar soluções tecnológicas para o agronegócio da bovinocultura da região Sudeste, que promovam a sustentabilidade da atividade econômica com o equilíbrio ambiental;

- viabilizar soluções tecnológicas que contribuam para diminuir os desequilíbrios sociais na região Sudeste;

- viabilizar soluções tecnológicas para o fornecimento de alimentos e de matérias-primas resultantes da bovinocultura que promovam a saúde e a melhoria da qualidade de vida da população. 
Vale ressaltar aqui, duas expressões constantes no II PDU, em que a Unidade evidencia sua preocupação com a agricultura familiar, segmento importante dentro da cadeia do agronegócio, por exemplo, da bovinocultura de leite; estas foram inclusas nos objetivos específicos (EMBRAPA, 2000:29):

"- fornecer a base de conhecimentos e tecnologias em bovinocultura para estabelecimentos familiares;

- melhorar o desempenho dos sistemas de produção de leite, visando à sustentabilidade econômica e ecológica da agricultura familiar".

Esta observação é salutar para que se compreenda, mais à frente, a análise do estudo de caso que será feita sobre as representações sociais dos produtores pertencentes a este segmento da agropecuária brasileira, o qual teve, ao longo dos tempos, histórias de exclusão, acessos ineficientes ou não acessos às políticas públicas de desenvolvimento para a agricultura.

Atualmente, a Unidade conduz suas atividades norteadas pelo seu III PDU (2004-2007), cuja missão já foi descrita no capítulo I deste trabalho. Na reflexão trazida pela sociedade, por meio das discussões e análises de cenários realizadas por pesquisadores da própria instituição, especialistas externos e pelo Conselho Assessor Externo - CAE, a Unidade amplia seu horizonte da produção científica que girava em torno do desenvolvimento da pesquisa em bovinocultura e incorpora "(...) atividades voltadas para o desenvolvimento rural, com 0 enfoque em pesquisa, desenvolvimento e inovação - P\&DI" (EMBRAPA, 2000:3).

Desta forma, no conjunto das propostas contidas em sua missão, visão, valores e foco de atuação, a instituição, em consonância com as políticas governamentais, dá ênfase à “(...) inclusão social, a segurança alimentar, as expectativas de mercado e a qualidade do ambiente (...)", bem como busca contribuir "(...) para a redução dos desequilíbrios regionais e das desigualdades sociais e para a gestão sustentável do ambiente e dos recursos naturais (...)" (EMBRAPA, 2000:21).

Agrega ainda, como valor, a responsabilidade social, expressa na proposta de interação permanente "(...) com a sociedade, na antecipação e na avaliação das consequências sociais, econômicas, culturais e ambientais da ciência e da tecnologia (...)" e contribui "(...) com conhecimentos e tecnologias para a redução da 
pobreza e das desigualdades regionais e a promoção da eqüidade" (EMBRAPA, 2000:22).

A visão da Unidade é de apoio às políticas públicas para a sustentabilidade do espaço rural. Desta forma, desenvolve suas ações e estabelece suas linhas de pesquisa a partir das estratégias propostas e implementadas em seu Plano Diretor da Unidade - PDU. Estas, contudo, devem estar alinhadas com o Plano Diretor da Embrapa - PDE e as prioridades de governo definidas no seu Plano Plurianual (EMBRAPA, 2005). Sem, no entanto, desconsiderar a análise do ambiente externo, no qual situa-se clientes, usuários, os competidores e os parceiros que influenciam e são influenciados pela Embrapa Pecuária Sudeste (EMBRAPA, 2000).

O centro de pesquisa Pecuária Sudeste, em sua trajetória, propôs ações de pesquisa voltadas a atender o cenário que se construía dentro do contexto da modernidade. Além disso, deveria estar conciliadas às propostas do PDE, não fugindo aos propósitos deste. Neste caso, seu objetivo também busca o aumento da produtividade a partir do desenvolvimento do conhecimento e da inovação tecnológica.

Assim, em seus documentos orientadores para o desenvolvimento de pesquisa, ou seja, em seus PDU's, a Pecuária Sudeste propõe ações que garantissem ou promovessem a sustentabilidade ampliadas à inclusão social.

No Plano Diretor, instrumento de gestão da Unidade, expõe-se à sociedade suas linhas de ação e estratégias ao enfrentamento dos desafios futuros - que no contexto da modernidade significa urgência - qual seja o "(..) desenvolvimento sustentável do espaço rural e a competitividade da pecuária bovina (...)" (EMBRAPA, 2005:7).

Para a Embrapa Pecuária Sudeste, os desafios postos à inovação tecnológica para os produtos da bovinocultura, não poderiam ser outro, senão, àqueles postos pelo cenário de um mercado globalizado.

Assim, consulta a especialistas também se fez necessário quando da construção do seu instrumento de gestão, ou seja, o PDU; o qual tomou por base “(...) consultas feitas a pesquisadores e a especialistas do ambiente interno e externo" à empresa (EMBRAPA, 2005:7); cuja proposta contempla demandas do mercado globalizado, por que não dizer, de um mercado de transformações urgentes e constantes, a qual exige: 
"(...) a geração de tecnologias, conhecimentos, produtos e serviços adequados às novas demandas relacionadas à melhoria da qualidade dos produtos, da qualidade de vida da população, da segurança alimentar, e da sustentabilidade ambiental, econômica e social, dentre outras" (EMBRAPA, 2005:12).

As novas demandas geradas nada mais são do que o reflexo de um cenário mundial, no qual a necessidade do aumento da produtividade de alimentos, bem como de bens e serviços, atende ao chamado do consumismo exacerbado promovido por uma globalização, aliado ao aumento populacional.

Recentemente, a unidade realizou um debate, por meio de uma oficina de trabalho, no qual buscou a reflexividade sobre os rumos que a pesquisa deste centro devem seguir frente aos cenários futuros. Desta reflexão, quatro grandes temas foram elencados, os quais podem vir a subsidiar as discussões para a formulação do PDU 2008-2011 e, uma vez contemplados, espera-se que balizem suas próprias práticas. São eles:

- qualidade e segurança do produto;

- eficiência e sustentabilidade da produção agropecuária;

- transferência de tecnologia e inovação para o desenvolvimento do agronegócio;

- desenvolvimento e fortalecimento institucional.

Vale salientar que, para dinamizar suas ações, os instrumentos utilizados pela Unidade contemplam normas, regras e procedimentos, cujas práticas também devem seguir o princípio da impessoalidade, o qual, como empresa pública, deve preservar.

Ao longo da história, é difícil precisar quando, exatamente, um determinado padrão tecnológico substitui o outro, mesmo porque, por se caracterizar num processo, ele é dinâmico e ocorre em estágios. Muitas das vezes se sobrepõe ao método tradicional, em outras, talvez, se complementem ou ainda caminhem juntas. Não existe, na verdade, um divisor de águas, ou seja, a partir de agora o que vai existir é esse ou aquele padrão; a inovação pode trazer algo do tradicional, mesmo porque a primeira, algumas vezes, incorpora métodos do segundo, aprimorando-o. 
No próximo capítulo abordaremos questões relacionadas a um grupo social de práticas tradicionais com o qual esta empresa pública da modernidade tenta interagir. 


\section{CAPÍTULO 3}

\section{AGRICULTURA FAMILIAR: UM MODO DE VIDA DA TRADIÇÃO}

No presente item, não se pretende caracterizar a agricultura familiar em seus aspectos quantitativos no tocante ao seu contingente, sua distribuição geográfica, por área, hectare, localização; valor da produção ou quanto é produzido; sua contribuição para o Produto Interno Bruto - PIB; tamanho da propriedade, enfim, características que lhe seja objetivas ou censitárias.

O que se pretende, é lançar mão das discussões ocorridas nos diferentes espaços acadêmicos e científicos, e abordar uma caracterização subjetiva focada no sujeito "agricultor familiar" e que contemple questões das dimensões materiais e imateriais no âmbito da unidade produtiva, e que Ihe confere diferenciações (modo de fazer, modo de vida, pensar, valores etc.), as quais se manifestam a partir de suas dinâmicas e interações, tanto com seu ambiente interno quanto externo, na busca pela manutenção das suas condições de reprodução sócio-econômica, cultural e ambiental.

A partir deste entendimento, abordaremos itens referentes ao perfil desse sujeito, não apenas sob o olhar do Estado, pelos órgãos constituintes no tema da agricultura, mas também para estudiosos na área.

\subsection{Um conceito ou uma identidade?}

Agricultura familiar não é exatamente um termo novo, mas seu uso recente, com certa capilaridade nos meios acadêmicos, nas políticas de governo e nos movimentos sociais, adquire novas significações e requer melhor compreensão das suas práticas e construção dos seus saberes.

Uma definição acerca da agricultura familiar, ou da forma de organização do trabalho e sua produção agrícola, contribui para a compreensão de suas características em sociedades capitalistas (SCHNEIDER, 2003).

No Brasil, o sujeito agricultor familiar ou o homem rural, recebe diferentes denominações dependendo da região onde está inserido, pois seja o "roceiro" e "caipira", nos Estados de São Paulo, Minas Gerais, Goiás e Paraná. No Nordeste, ele é chamado de "tabaréu" e em diversas regiões o chamam de "caboclo" (MARTINS, 1986). 
Não obstante, se faz referência ao agricultor, aquele que vive no campo ou na roça e, normalmente, é rotulado de pessoa rústica, atrasada e ingênua. É comum, às vezes, ouvir expressões depreciativas, do tipo: o produtor rural é atrasado ou é preguiçoso. Uma construção social, na qual the confere atributo de valor depreciativo, ou seja, criando um estereótipo do homem destituído pela ausência de contato com os valores e meios materiais da modernidade e do meio urbano, o que o seu traje, modos e entorno o afirme (Foto 3).

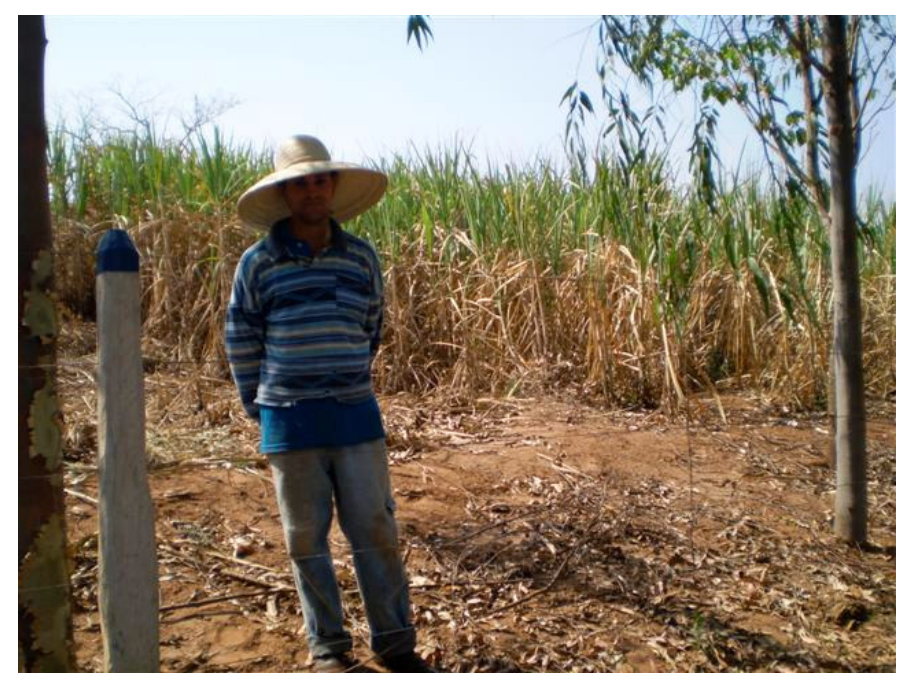

FOTO 3: um camponês, circunscrito a seu meio.

Independente desses traços que desqualifica e inferioriza o agricultor familiar, o importante é considerar que a história dos produtores de alimentos no Brasil e para o mercado interno, está ligada às diferentes trajetórias de grupos sociais. São eles: os índios, escravos africanos, os mestiços, os brancos não herdeiros e os imigrantes europeus (ALTAFIN, 2007).

O conceito de camponês é sintetizador de práticas múltiplas da produção familiar do país no século XX, ou seja, ele traduz suas peculiaridades em torno da produção baseada na policultura, cujos sistemas se aproximam do ambiente natural no qual estão inseridos e, ainda, a produção para o autoconsumo e a característica do trabalho e gestão familiar indissociáveis. Também, atrela-se a ele uma imagem depreciativa baseada em "alguém que vive em condições muito precárias, que tem um acesso nulo ou muito limitado ao sistema de crédito, que conta com técnicas tradicionais e que não consegue se integrar aos mercados mais dinâmicos e competitivos" (ABRAMOVAY, 1997:74). 
Com o golpe militar de 1964, dentro da lógica de modernização rural, o conjunto de agricultores passa a ser classificado quanto ao tamanho de suas áreas e de sua produção. Os camponeses passam, então, a ser tratados como pequenos produtores. Na década de 1980, o Brasil vive um novo momento político com a redemocratização do País. Junto com ele, a retomada dos movimentos organizados no campo, como o movimento sindical dos trabalhadores rurais em conjunto com a Confederação Nacional dos Trabalhadores na Agricultura - CONTAG, os quais reivindicam para a pequena produção o direito a terra, por meio da reforma agrária, direitos trabalhistas, assistência técnica, financiamento à produção, políticas agrícolas específicas, entre outros; mas, acima de tudo, o seu reconhecimento como trabalhador autônomo e assim inseri-lo como uma categoria social, ou seja, criou condições para uma conformação e representação dos interesses do pequeno produtor. Tais elementos passam a fazer parte da pauta de reivindicações nos congressos e manifestações da organização (MEDEIROS, 1997 e ALTAFIN, 2007).

$\mathrm{Na}$ década de 1990, a partir da reflexividade desses grupos organizados, ocorre uma maior pressão sobre o Estado por políticas que incluam a pequena produção no processo de desenvolvimento do País, resultando em diversos programas de governo, entre eles, o Programa Nacional de Fortalecimento da Agricultura Familiar - PRONAF, de abrangência nacional e exclusivo para a produção familiar, ou seja, um instrumento para sua afirmação no cenário social e político legitimada pelo Estado (SCHNEIDER, 2003).

Concomitantemente, pesquisas acadêmicas refletem sobre o papel exercido por esses agentes na estrutura político-econômica do País e buscam formas de inseri-los no processo de desenvolvimento. "É nesse contexto que o termo agricultura familiar se consolida e se difunde nos diferentes setores da sociedade" (ALTAFIN, 2007:10).

A importância da agricultura familiar é algo indiscutível no cenário mundial, prova disto, é a sua inclusão nas políticas públicas de vários países. Ainda que não haja consenso quanto ao significado do seu conceito, no Brasil, com a política pública de inclusão social, ela é considerada não somente um instrumento de desenvolvimento sócio-econômico, mas também de fortalecimento da democracia (EMBRAPA, 2006).

Para a aplicação das políticas públicas ou, na forma da Lei, o conceito de agricultura familiar obtém um formato, digamos "operacional", centrado na 
característica geral de um grupo social heterogêneo. Já no meio acadêmico, encontramos diversas compreensões sobre o conceito de agricultura familiar, propondo uma abordagem mais reflexiva e menos operacional do termo (ALTAFIN, 2007).

Segundo Altafin (2007), as contribuições para delimitar o conceito de agricultura familiar vêm de diversas correntes e destaca duas delas: "uma que considera que a moderna agricultura familiar é uma nova categoria, gerada no bojo das transformações experimentadas pelas sociedades capitalistas desenvolvidas. $E$ outra, que defende ser a agricultura familiar brasileira um conceito em evolução, com significativas raízes históricas" (ALTAFIN, 2007:1).

A primeira corrente desconsidera a necessidade de buscar as origens históricas do conceito, pois argumenta que as diferenças conceituais estão relacionadas com os diferentes ambientes sociais, econômicos e culturais, bem como por considerarem os agricultores familiares modernos, ou seja, um fenômeno recente. Assim, os desvincula da herança do passado.

Para a segunda corrente de pensamento, a qual considero ser mais pertinente à realidade observada neste estudo, “(...) as transformações vividas pelo agricultor familiar moderno não representam ruptura definitiva com formas anteriores, mas, pelo contrário, mantém uma tradição camponesa que fortalece sua capacidade de adaptação às novas exigências da sociedade" (ALTAFIN, 2007:1).

Wanderley (1999) corrobora quando expressa a realidade brasileira ao dizer que o agricultor familiar, mesmo que moderno, "(...) guarda ainda muitos de seus traços camponeses, tanto porque ainda tem que 'enfrentar' os velhos problemas, nunca resolvidos, como porque, fragilizado, nas condições da modernização brasileira, continua a contar, na maioria dos casos, com suas próprias forças" (WANDERLEY, 1999:52).

Vai daí, por exemplo, a distinção dos meios materiais com os quais opera, a utilização da tração animal, num contexto no qual a tração mecânica predomina, o que, no caso do primeiro, dependendo do seu contexto produtivo, pode acarretar maior competitividade (Foto 4). 

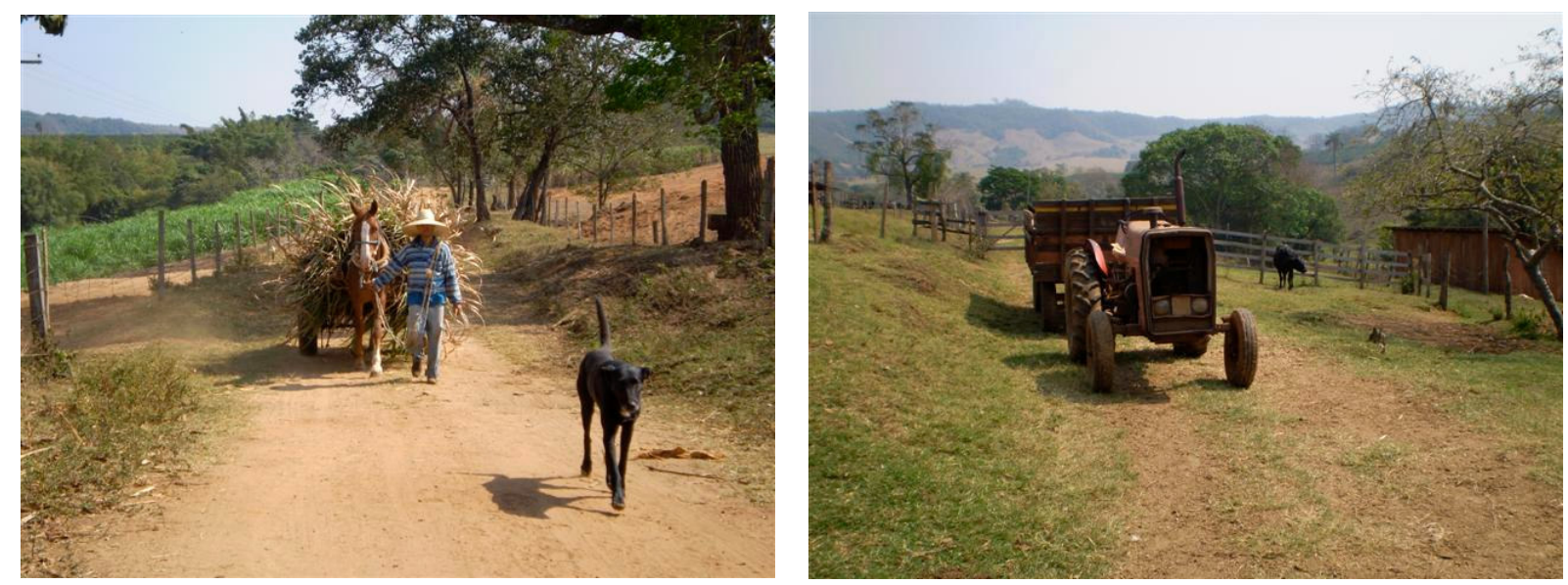

FOTO 4: os meios materiais no campo vão da tração animal à mecanização, definindo diversos níveis de assimilação das inovações voltadas para o meio rural.

O conceito de agricultura familiar, embora seja um termo relativamente novo, apresenta extensa trajetória em termos bibliográficos, expressando o intenso debate sobre as características desse segmento.

Apesar da existência de pontos divergentes quanto aos princípios definidores, é possível reconhecer um certo consenso; ou seja, por agricultura familiar entendese, em termos gerais, uma unidade de produção onde trabalho, terra e família estão intimamente relacionados.

Bianchini reitera: o "conceito de agricultura familiar (...) adotado por pesquisadores em todo o mundo ao longo dos tempos, (...) é o do predomínio do trabalho familiar no estabelecimento agropecuário, identificando uma correlação forte entre gestão, trabalho e posse total ou parcial dos meios de produção" (BIANCHINI, 2007:1).

Lamarche (1993), em seu estudo comparativo internacional, também adota um conceito que congrega estes fatores e diz que "A exploração familiar, tal como a concebemos, corresponde a uma unidade de produção agrícola onde propriedade e trabalho estão intimamente ligados à família" (LAMARCHE, 1993:15).

Tais percepções acadêmicas foram ratificadas durante este estudo, observouse que o ambiente doméstico e o local de trabalho não se diferenciam, papéis e funções dos membros da família transitam entre um ambiente e outro (Foto 5). 

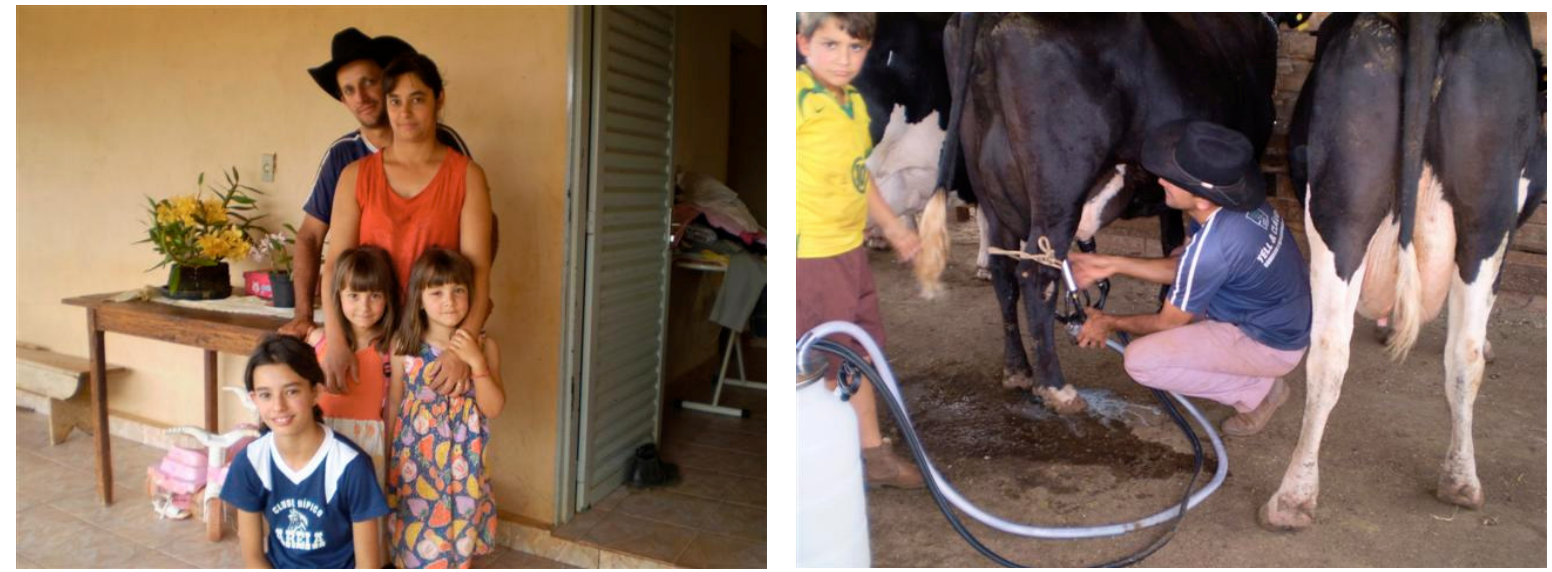

FOTO 5: família e trabalho: aspectos indissociáveis do modo de vida da agricultura familiar.

Ressalta, ainda, o fato de que questões como transmissão do patrimônio e reprodução material estão imbuídos de uma lógica própria.

Contudo, para este trabalho - mais especificamente para identificação deste grupo na pesquisa de campo, lançamos mão da descrição oficial do conceito de agricultor familiar constante na legislação federal sob a Lei 11.326, aprovada pelo Congresso Nacional e sancionada pelo presidente da República em 24 de julho de 2006. Esta lei considera:

“(..) agricultor familiar e empreendedor familiar rural aquele que pratica atividades no meio rural, atendendo, simultaneamente, aos seguintes requisitos: I - não detenha, a qualquer título, área maior do que 4 (quatro) módulos fiscais; II - utilize predominantemente mãode-obra da própria família nas atividades econômicas do seu estabelecimento ou empreendimento; III - tenha renda familiar predominantemente originada de atividades econômicas vinculadas ao próprio estabelecimento ou empreendimento; IV - dirija seu estabelecimento ou empreendimento com sua família" (Brasil, 2006).

A descrição oficial do conceito de agricultura familiar combina critérios de tamanho da propriedade, predominância familiar da mão-de-obra, maior parte da renda vinda da propriedade e gestão familiar da unidade produtiva.

Todavia, embora haja esta delimitação oficial do conceito, é pertinente considerar as diferentes situações que retratam a realidade deste sujeito social, as 
quais contemplam sua subjetividade e suas práticas, caracterizando seu modo de ser e de fazer que Ihes são peculiares e que Cândido traduz muito bem:

"O despertar é geralmente às 5 horas, seguindo de pequena ablução, consistindo um pouco de água pelos olhos. Segue a primeira refeição e a ração de milho às criações. Parte-se então para o local de trabalho... A faina encetada vai até o pôr do sol (...)" (CÂNDIDO:1964:95).

O local de trabalho, reitero, se funde com seu local de moradia, ou seja, é ali, tudo acontecendo ao mesmo tempo. São tais aspectos que serão considerados para a análise dos seus processos interativos.

É neste contexto que o produtor familiar organiza suas práticas diárias, nas quais ao mesmo tempo em que negocia a venda do seu produto, é o instante em que também colhe alimentos para o sustento da sua família. A produção da horta doméstica e a criação de pequenos animais, para consumo interno, é comum nas propriedades familiares (foto 6).
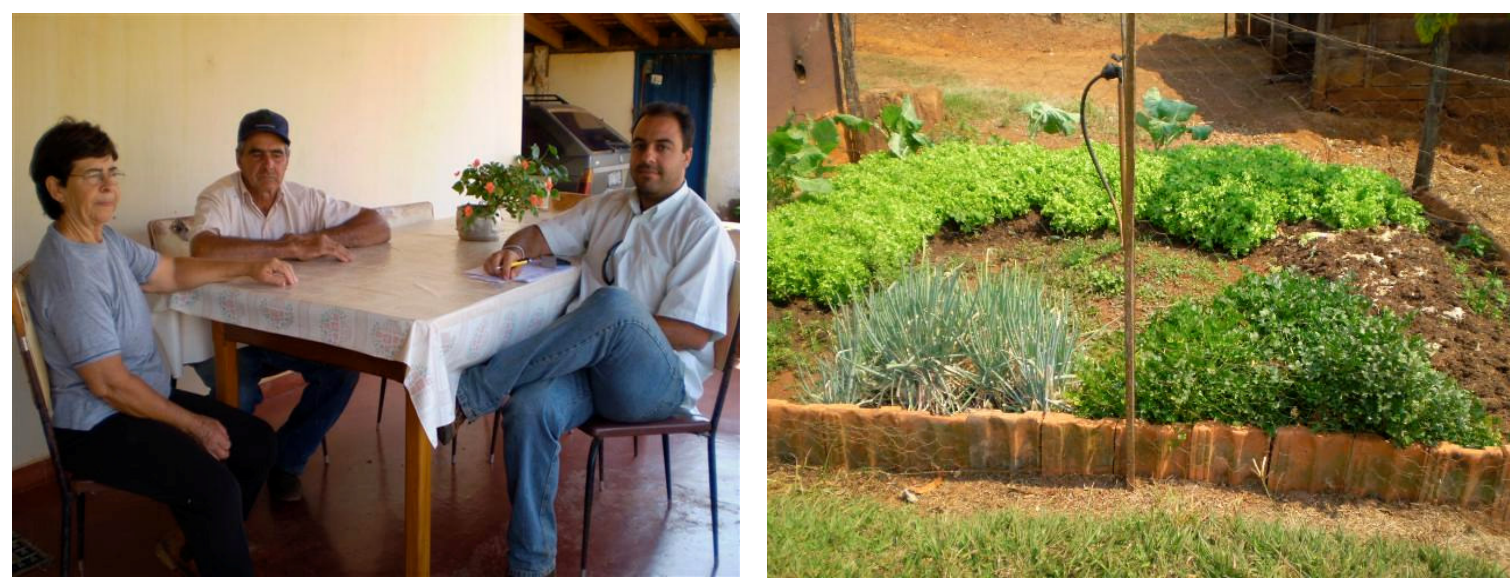

FOTO 6 - local de trabalho e de residência: presença do técnico da cooperativa e horta doméstica para consumo da família.

Partindo deste pressuposto, não seria prudente negligenciar o fato de que "(...) o uso do termo 'agricultura familiar' no Brasil se refere a um amplo guarda-chuva conceitual, que abriga distintos tipos e situações, não apenas entre as regiões, mas dentro de cada estado, de cada município ou de um território" (ALTAFIN, 2007:15).

Dada à heterogeneidade apresentada pela agricultura familiar, os autores reconhecem os limites para uma tipologia adequada; por isso, na literatura, é possível encontrar diferentes tipos para categorizar este sujeito social. Desta forma, 
Carneiro (1999) considera a necessidade de eleger critérios que mais se adaptem ao propósito da classificação.

Carneiro (1999:327), por exemplo, sugere uma classificação “(...) voltada para análise dos processos sociais, centrada na identificação da lógica de reprodução social e nas diferentes estratégias sociais implícitas", cujas dimensões seriam o investimento diferenciado no mercado a partir de estudos regionalizados e foco qualitativo. Propõe ainda, que este esforço de classificação leve em conta dois fatores: tradição cultural e a trajetória das unidades familiares.

Lamarche (1993), no estudo comparativo internacional, já referido, pautou sua tipologia no grau de dependência ao mercado, cujo cerne estava na lógica de organização da agricultura familiar, na qual apresenta predominância da mão-deobra familiar e a busca constante pela estabilidade da terra como forma de manutenção de reprodução da família.

O Estado, em seu programa institucional, exclusivo para a agricultura familiar, qual seja o PRONAF, classifica os agricultores familiares de maneira objetiva e quantitativa, enquadrando-os em grupos, cujo foco é a origem da renda e o patamar para o limite de crédito, com juros diferenciados e descontos no pagamento.

Desta forma, para fins do crédito do PRONAF, as famílias são enquadradas nos grupos "A", "A/C", "B", "C", "D" e "E". Esta classificação leva em conta a renda bruta anual gerada pela família, o percentual dessa renda oriundo da atividade rural, o tamanho e gestão da propriedade e a quantidade de empregados na unidade familiar (FERREIRA, 2007:3).

É relevante notar, a incorporação paulatina, por esse grupo, de um padrão "moderno" que o condiciona a novos ajustes de suas práticas e das suas relações interpessoais e com o meio circundante. Sem, contudo, abrir mão completamente dos aspectos da sua identidade, da sua memória e a valorização do espaço da terra como lugar do "bonito", de vínculo com a natureza. Enfim, da sua lógica própria.

"Sim porque se o ambiente você cuidar dele certinho ele vai te dá retorno né?... É a propriedade da gente que a gente tá conservando, uma propriedade mais bonita..."

(agricultor familiar $\mathrm{C}$ ) 
"Hoje o que eu mais gosto é ver meu gado bem tratado, ver o gado bonito, saudável e produzindo muito leite, isso pra gente se torna além de ser uma obrigação, ainda se torna um hobe, porque você olha a vaca com úbere bonito e dando muito leite, passa a ser uma alegria muito grande".

(agricultor familiar D)

O lugar é um espaço privilegiado dessa memória e de vida local, no qual se constrói a identidade e, no ambiente da modernidade, ele é dinâmico, conforme descreve Silva: "Numa sociedade moderna, os agricultores não se diluem em um meio disperso, mas constroem um espaço de vida, o espaço local no qual as relações de interconhecimento se revitalizam" (SILVA, 1999a:166).

Muitos dos fatores observados, na tentativa de se construir um conceito para a agricultura familiar, trazem em seu cerne aspectos do seu modo de ser e de inserção na sociedade integrados às suas práticas, estas por sua vez, são organizadas a partir das suas crenças que estão vinculadas à tradição, cuja experimentação cotidiana lhe confere a sabedoria para reconhecer alguns fenômenos advindos do mundo natural, como por exemplo, decifrar o comportamento do animal diante de determinada situação.

\footnotetext{
"Vaca de leite eu vou te contar uma coisa, o bicho é exigente, ela sabe direitinho onde tá melhor, ela começou a ficar muito perto do curral, pode saber que ela quer mudança de pasto. Na seca, você solta elas ficam tudo amontoada esperando comida, começou chover, dentro de uns dez dias, você vai tirando, soltando, não fica nenhuma aqui...".

(agricultor familiar B)
}

De acordo com Giddens (1991), a tradição é significativa para a segurança ontológica, pois está relacionada com a confiança de que as coisas continuarão a acontecer da mesma forma que antes. Assim, para o agricultor familiar, a tradição Ihe confere certa tranquilidade e seguridade de êxito na realização de suas tarefas. Significa que as coisas precisam acontecer obedecendo a uma determinada seqüência conhecida, sob o risco de fazê-lo perder o "norte". 
"Porque toda vida eu gostei, desde que eu era solteiro eu tirava o leite... Não, eu acho se eu parar do leite, eu fico perdido, fico mesmo porque todo dia cedo meu trabalho é ir lá buscar a vaquinha e tirar o leitinho, então eu acho que eu fico meio perdido".

(agricultor familiar $\mathrm{G}$ )

Não se quer dizer, entretanto, que a tradição apresente sempre situações plenas de conforto e estabilidade, mas que, em ambientes modernos, o nível de risco para a segurança ontológica, aumenta consideravelmente (GIDDENS, 1991).

Esse conjunto de fatores, que norteia o cotidiano do agricultor familiar, nos leva a crer que configura traços da sua identidade e os diferencia da lógica do mercado globalizado.

Se a definição ou a identidade do agricultor familiar constitui-se no âmbito das idéias, valores, símbolos e sentimentos, são nas suas estratégias para a manutenção do patrimônio e da família que elas se materializam; é o que discutiremos a seguir.

\subsection{Estratégias de reprodução material}

Relegada a segundo plano, ou mesmo esquecida pelo Estado, a agricultura familiar e a sua base de reprodução - a pequena propriedade, tem sobrevivido em meio a uma competição desleal, cujas condições e recursos têm favorecido a grande produção e a grande propriedade. Reflexos da modernização da agricultura brasileira.

Atualmente, a discussão sobre a valorização da agricultura familiar vem ganhando legitimidade social, política e acadêmica no Brasil, tomando corpo em meio ao fortalecimento dos movimentos sociais.

A produção oriunda da agricultura familiar é heterogênia, pois apresenta diferentes condições de produção como: o tamanho da propriedade, o grau de contratação ou interação com técnicos, o acesso ao crédito, o tipo de capital cultural e relação do produtor com o mercado (CARNEIRO, 1999). Portanto, exige uma acuidade maior na descrição dos aspectos que a caracteriza.

Imbricado nesta heterogeneidade, há a pluriatividade, a qual está relacionada “(...) a fatores tais como situações dos produtos, nível educacional, acesso às 
instituições de saúde, meio ambiente, aptidão das terras, a disponibilidade de infraestrutura, e a um conjunto formado por elementos culturais, ambientais e econômicos" (EMBRAPA, 2006b:12).

Para compreender como tal segmento persiste e insiste ao longo da história, é preciso reconhecer a capacidade da agricultura familiar de se adaptar a situações diversas, em diferentes contextos históricos e conjunturais, e de elaborar novas estratégias para se adaptar às condições econômicas e sociais. Advém disso, talvez, o modo do produtor, dificilmente, desfazer-se de objetos considerados "lixo" por alguns (Foto 7).

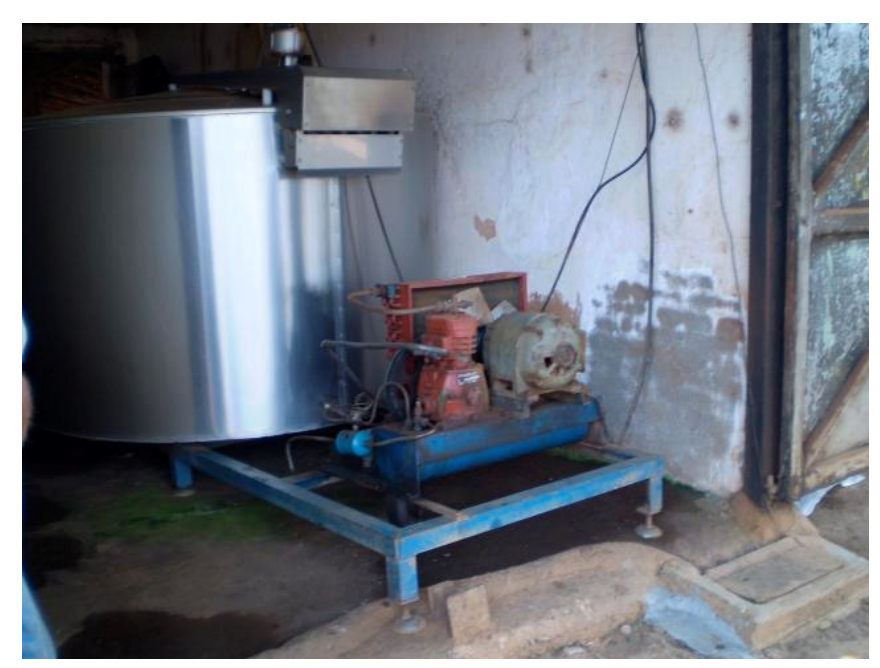

FOTO 7: motor antigo adaptado ao tanque de expansão - forma de reduzir custo, economia de dois mil reais (aproximadamente, dois mil e oitocentos litros de leite a preços da época).

Nesse sentido, a unidade familiar não pode ser concebida como uma estrutura rígida ou que, em certa medida, não possa ser mudada (a lógica tradicional, contudo, permanece). Ao contrário, é sua relativa permeabilidade que norteará sua reprodução social (SILVA, 1999b).

Tanto quanto o meio envolvente incita ações e reações coletivas da agricultura familiar, a dinâmica interna da unidade familiar confere uma certa autonomia na formulação das estratégias reprodutivas e na sua articulação com o ambiente externo. Tal dinâmica e flexibilidade, na elaboração das novas estratégias, não raramente, dialogam com a tradição - rejeitando-a ou valorizando-a - ou seja, novos valores podem ser formulados ou antigos valores serem resgatados na busca do equilíbrio ou de respostas da família às crises familiares da unidade econômica (CARNEIRO, 1999). 
A rotina do agricultor familiar é baseada numa lógica própria que atende ao compasso no qual, ao término do dia, sua tarefa foi cumprida e o descanso é devido. As novas demandas, advindas do processo de modernização da agricultura, requerem do produtor uma outra organização das suas atividades, as quais precisam ser reinventadas e reorganizadas a fim de se cumprir seu labor no tempo hábil exigido pela nova realidade.

"Então, por exemplo, antes você tinha o funcionário, tinha a carrocinha, tinha o cavalinho, acabava de tirar o leite, passava ali no silo tirava o trato da tarde, jogava na carroça distribuía nos cochos. Hoje, a gente já faz o seguinte: já põe a pazinha no trator, pazinha traseira, você já vai lá ranca ela coloca direto no cocho, se você não fizer isso, você não da conta do serviço do dia (...)".

(Agricultor familiar B)

Não obstante, os conhecimentos tradicionais de gestão que ultrapassam o âmbito do cultivo e se acomodam em toda propriedade, com suas inter-relações e complementariedades, constituem também um patrimônio cultural, pois seus resquícios ainda estão presentes nas novas práticas modernas dos sistemas agrícolas, evidenciados, por exemplo, nas ajudas mútuas e mutirões, os quais se estabelecem na tentativa de superar as dificuldades na produção ou na sobrevivência da família.

\footnotetext{
"Tem o [vizinho] aqui que nós trabalhamos até junto quando vamos plantar, fazer silo. Já não vai ser esse ano, porque a gente não vai fazer silo mais, mas a gente está sempre em contato".

(agricultor familiar A)
}

Silva (1999a), ressalta que: "Neste quadro, práticas como o autoconsumo, a reutilização de produtos, a redução do endividamento e a ajuda mútua aparecem não como signos do atraso de uma agropecuária arcaica, mas como estratégias de adequação a condições adversas" (SILVA, 1999a:161).

Lamarche (1993), descreve algumas estratégias adotadas pela agricultura familiar. Uma primeira, refere-se àquelas utilizadas pelos agricultores para obtenção da terra. No interior dos sistemas de produção familiar, o valor da terra vai além do 
significado material do patrimônio e meio de reprodução: ela é marcada por um caráter mais simbólico e de pertencimento ao lugar.

Seguindo, tem-se as estratégias familiares de reprodução social, especialmente àquelas voltadas ao destino dos filhos. "Para muitos, o êxodo aparece como a busca de liberdade e a recusa de um meio tido como fechado e medíocre. Para outros, significa uma fuga das incertezas" (SILVA, 1999a:165). Todavia, o fato é que o destino dos filhos afeta o sentimento de identidade dos agricultores.

\footnotetext{
"Quem manda é a influência dele [filho] também, que vai mandar, porque nós já estamos de meio dia pra tarde, então ele [filho] quem vai influir... Eu então, eu chorei, foi o [filho] que mais me ajudou..." (agricultor familiar G)
}

Outro item, representa o trabalho familiar agrícola face à pluriatividade. Aqui é importante ressaltar o caráter desse fenômeno, que não é tão novo, e que constitui a realidade de muitas unidades familiares, a qual vai além de uma alternativa de emergência frente à crise provocada pela modernização da agricultura, pode significar uma opção pessoal que, não necessariamente, deva estar vinculada aos interesses do grupo familiar (CARNEIRO, 2005):

\footnotetext{
"Eu sou aqui do lar, faço pastel, vou trabalhar na feira...". (esposa do agricultor E)

"Hoje era pra eu tá vendendo doce, porque minha caminhonete estragou".

(agricultor familiar C)
}

Embora se trate de uma opção, que pode ser individual ou familiar, pode significar uma escolha de participar da reprodução da família de forma a aliar o âmbito privado com o público, garantindo o patrimônio familiar. Schneider (2003) aponta esse envolvimento dos membros mais velhos para gerar novas alternativas de renda para o grupo, dentre outros.

No conjunto dessas estratégias, que ajuda a compreender o modo como a agricultura familiar costura suas relações, Abramovay (1997) faz a consideração 
que, ao lado das unidades produtivas pequenas, em condições precárias, cuja renda é pouca:

“(...) desenvolve-se também um segmento familiar dinâmico capaz de integrar-se ao sistema de crédito, cujo comportamento econômico difere da famosa e tão estudada aversão ao risco, que adota a inovação tecnológica e integra-se a mercados competitivos" (ABRAMOVAY, 1997:4)

O autor ressalva que este dinamismo depende de fatores como sua base material de produção, a formação dos agricultores e do ambiente-sócio econômico em que estão inseridos; sobretudo, se este the permite o acesso a diversos mercados, ao crédito, à informação e aos meios materiais de exercício da cidadania como escola, saúde, assistência técnica, entre outros.

Carneiro (1999), contudo, pondera que a compreensão da unidade de produção familiar não deve ficar limitada à dinâmica econômica (produtividade, rentabilidade, competitividade), pois o sucesso econômico, expressado pelo incremento da produtividade e renda, não necessariamente, significa bem estar social e cultural, principalmente se vem acompanhado da exploração da força de trabalho ou da destruição dos laços de solidariedade e da estrutura familiar.

É necessário levar em conta que a importância da agricultura para as famílias rurais vai além da produção para o mercado. Contempla, também, as motivações culturais e sociais para, entre outras, garantir a manutenção da sua identidade como homem do campo. Assim, o seu significado pode ser dado por outros fatores sociais, já que a produção não ocorre no espaço vazio social, nem se resume a uma atividade isolada.

É nessa perspectiva que Santos (1999:5 e 6), descreve este modo de gerir a propriedade que é típico do agricultor familiar.

"É o administrador do empreendimento, responsável pelos rumos estratégicos, guiando a enxada na leira da roça. É a bateção do feijão para o almoço de hoje e o pensamento no aumento do patrimônio de amanhã". 
"Enfim, esse sujeito que no miúdo do dia-a-dia, na toada serena da marcha e no pêndulo da foice durante a roçada, vai construindo a solidez do patrimônio que deixará para os filhos."

As discussões contidas neste capítulo, sugerem uma agricultura familiar que se pauta num modo de vida peculiar, no qual baseia-se nas relações interpessoais e de trabalho. Dada a sua heterogeneidade, não é possível atribuir um conceito que a caracterize como uma "categoria" social; porém, três aspectos são básicos: trabalho, família e propriedade. Muitas das suas práticas são baseadas naquelas aprendidas de sua herança familiar, cujo valor afetivo é relevante. Contudo, é possível a adoção de práticas modernas, conjugadas às tradicionais, talvez como forma de resistência à primeira e garantia de manutenção da sua autonomia. Sua capacidade adaptativa constitui-se uma estratégia para garantir sua reprodução material e proteção do patrimônio familiar.

O capítulo a seguir, refere-se a um estudo de caso, no qual muitos desses aspectos teóricos estão contidos. 


\section{CAPÍTULO 4}

\section{AS PRÁTICAS E REPRESENTAÇÕES TRADICIONAIS FRENTE Á INOVAÇÃO: LIMITES E POTENCIALIDADES}

A inovação tecnológica é uma prática social orientada por uma dada racionalidade econômica e visão de bem estar social. Modernamente, pressupõe melhoria das condições de trabalho, aumento da produtividade, diminuição dos custos de produção, acessibilidade a novos mercados, ampliação dos ganhos de capital, entre outros. A produção de conhecimento aplicado, é o instrumento propulsor da inovação, e se propõe a ampliar a acumulação. Assim, "as maravilhas da ciência e da técnica não se traduzem necessariamente na redução ou eliminação das desigualdades sociais entre grupos, classes, coletividades ou povos. Ao contrário, em geral preservam, recriam ou aprofundam as desigualdades" (IANNI, 1998:157). Nesse aspecto, as inovações não tendem a ser dialógica, mas serem instrumentos de poder que impõem padrões produtivos consoantes com os interesses hegemônicos do mercado, o que, no contexto da agricultura, se traduz em intolerância com a forma de produção e nos significados importantes que a peculiaridade tem para a unidade familiar produtiva.

A inovação tecnológica geralmente está associada à necessidade de resolver problemas relacionados ao setor produtivo vinculados ao crescimento econômico, o que impede que se leve em consideração o capital intelectual acumulado e o conjunto das representações e práticas sociais dos sujeitos, cuja trajetória de vida está no meio rural e na tradição, sobretudo se são da agricultura familiar.

Se os sujeitos no meio rural sentem-se desconsiderados na forma como os agentes da inovação tecnológica interagem, indicando seu conhecimento como o único válido para organizar a produção, sua inferiorização frente ao moderno não será o ponto desde o qual a permeabilidade irrestrita ocorra. Do contrário, a tentativa de subjugação da temporalidade própria do fazer em base familiar, pode suceder grande resistência do grupo, prendendo-se a hábitos que são conhecidos, cristalizados ou de uma rotina, mantendo-se numa zona confortável do já sabido com autonomia do fazer, balizado por sua crença, sua fé. 
"O projeto não recomenda fazer silo. Não vou fazer né, eu fazia agora não vou fazer, eles recomendam a cana que é mais barato que o silo. Eu tenho minhas dúvidas, porque chega na época... ele recomenda cortar a cana todo dia, o problema de vento, deita a cana então você transportar a cana pra cortar em volta do barracão é difícil, você tem uma mão-de-obra a mais, enquanto que o silo de milho, ele fica mais caro, mas ele tem uma qualidade melhor e tá pronto, tá garantido né? Enquanto que a cana você não perde, mas ela Ihe dá um trabalho quando ela deita muito incrível... Faria silo outra vez, de milho!"

(agricultor familiar A)

O conjunto das interações ocorrido nas relações sociais, sobretudo nas sociedades modernas, nos revela pontos importantes de convergências ou distanciamentos, tensão ou fluidez entre os grupos sociais envolvidos; o item que se segue trará à luz elementos que configuram essa interação.

\subsection{Discussão dos procedimentos do estudo de caso}

O ponto de partida deste trabalho foi analisar em que medida o Estado, como representante da modernidade, e por meio de suas novas práticas tecnológicas, é capaz de influenciar, ou não, o modo de vida da tradição entendida, neste estudo, como a agricultura familiar.

Neste caso, a Embrapa Pecuária Sudeste constitui a instituição pública que representa o Estado na produção de práticas inovadoras a partir das quais, direta ou indiretamente, tenciona reamoldar a produção da unidade familiar. Tais práticas se manifestam por intermédio dos projetos, razão pela qual nossa análise debruçou-se sobre o que que a Embrapa Pecuária Sudeste considera mais relevante para a produção de base familiar intitulado: "Balde Cheio". A caracterização do pensar e do fazer institucional dar-se-á por meio de uma amostra de empregados (técnicos) envolvidos no projeto, constituída por um conjunto de técnicas da seguinte forma (EMBRAPA, 2004a):

1) agropecuárias: uso intensivo de pastagem (pastejo rotacionado) no período das águas, cana-de-açúcar e uréia como suplementação alimentar no período da 
seca, controles reprodutivo e sanitário, técnicas de irrigação em pastagens e conforto térmico para os animais (sombreamento);

2) ambientais: recuperação e conservação da fertilidade do solo, plantio de matas ciliares, controle de efluentes e melhoria da qualidade da água;

3) gerenciais: controle zootécnico do rebanho, análise econômica e contábil, comercialização de produtos, práticas de associativismo e de agregação de valor.

O projeto tem como base a transferência desse conjunto de tecnologias para técnicos da extensão rural e, simultaneamente, ao produtor a partir da instalação de uma unidade demonstrativa chamada de "sala de aula". Na sequência, o técnico extensionista passa a ser o multiplicador desta tecnologia para outras unidades familiares, denominadas de "assistidas".

O conjunto da técnica proposto pela Embrapa, analisado neste estudo, de acordo com seu corpo técnico, sugere, entre outras coisas, sustentabilidade ambiental sob a forma da recuperação do pasto degradado por práticas tradicionais inadequadas, recomposição da mata ciliar, manutenção ou ampliação da área de preservação permanente, enfim, contribui para o cumprimento da legislação ambiental.

Procurou-se analisar a qualidade das interações ocorridas entre os sujeitos envolvidos nos pontos da relação, quais sejam: a Embrapa Pecuária Sudeste, localizada no município de São Carlos-SP, cujo principal produto de pesquisa é a pecuária bovina de corte e leite; e a produção familiar anunciada no projeto com amostra nos municípios de Cristais Paulistas e Ribeirão Corrente, região de Franca, interior do estado de São Paulo.

O município de Franca está localizada na região Nordeste do Estado de São Paulo e dista $401 \mathrm{~km}$ da capital paulista. Sua economia gira em torno da indústria, especialmente de calçados, e constitui-se um dos maiores pólos exportador do setor calçadista do País. A população é de aproximadamente 287 mil habitantes, cuja população rural não atinge seis mil moradores. O principal produto agrícola é a canade-açúcar, mas também planta café e arroz. A pecuária leiteira produz cerca de dez milhões litros/ano (IPES, 2002).

Os municípios de Cristais Paulista e Ribeirão Corrente localizam-se a 14 km e $30 \mathrm{~km}$ de Franca, respectivamente. A população do primeiro, é de aproximadamente 6.500 habitantes e a do segundo, é de cerca de quatro mil. Em ambos, atualmente, 
a população rural não atinge $50 \%$ do seu total; contudo, suas economias advêm da produção agropecuária, cujos principais produtos agrícolas são o café, milho, pastagem cultivada e a cana. A pecuária bovina leiteira também está presente entre os principais produtos destes municípios; juntos, eles são responsáveis pela produção de algo em torno de oito milhões de litros/ano (CATI, 2007).

É neste contexto, o qual encontram-se circunscritos os agricultores familiares constituintes da amostra.

A figura 2 demonstra o caminho percorrido para analisar as interações entre a Embrapa Pecuária Sudeste e os agricultores familiares envolvidos no projeto "Balde Cheio", no bojo do qual refletiremos acerca da indução do processo de modernização no seio de um modo de vida tradicional.

Cinco variáveis são, para tanto, tomadas, a saber:

- as representações sociais dos sujeitos envolvidos acerca de si próprio e do outro com o qual interagem no projeto.

A partir de tais representações sociais, parte-se para um detalhamento das condições materiais que colaboram no entendimento dos juízos, expectativas e percepções que os sujeitos constroem sobre si próprio e o outro.

No caso dos agricultores familiares, as variáveis são:

a) características da produção: relacionando os itens que tratam do tempo na atividade, com quem aprendeu a atividade, o que produz, suas práticas, tradição e a expectativa de mudar de atividade;

b) características da propriedade: cujos itens tratam do tempo que se encontra na propriedade, como a adquiriu, o tamanho, força de trabalho, organização/papéis, tempo dispensado/tempo livre, gestão, meio ambiente, apoio técnico;

c) características do mercado: baseou-se nos itens onde vende, de que forma e o acesso.

No caso da Embrapa Pecuária Sudeste, as variáveis principais são: a formação, a qual se atrela o cargo; tempo na empresa, que ganham importância nas práticas profissionais adotadas, que são a síntese da vinculação institucional.

A fim de melhor avaliar a qualidade das interações entre os sujeitos supra, um grupo de controle de agricultores familiares sem interação com a Embrapa Pecuária Sudeste, foi constituído. 
Para entendermos como os grupos em interação reconhecem as suas práticas, será preciso conhecer como ambos se enxergam mutuamente, é o que veremos nos sub-itens a seguir.

Vale ressaltar, neste momento que, por estarmos falando de um padrão de relacionamento, os relatos que compõem as interpretações, constituem relatos ilustrativos de um padrão de representação do grupo. Este esclarecimento é importante para que o foco não esteja no indivíduo e sim no grupo.

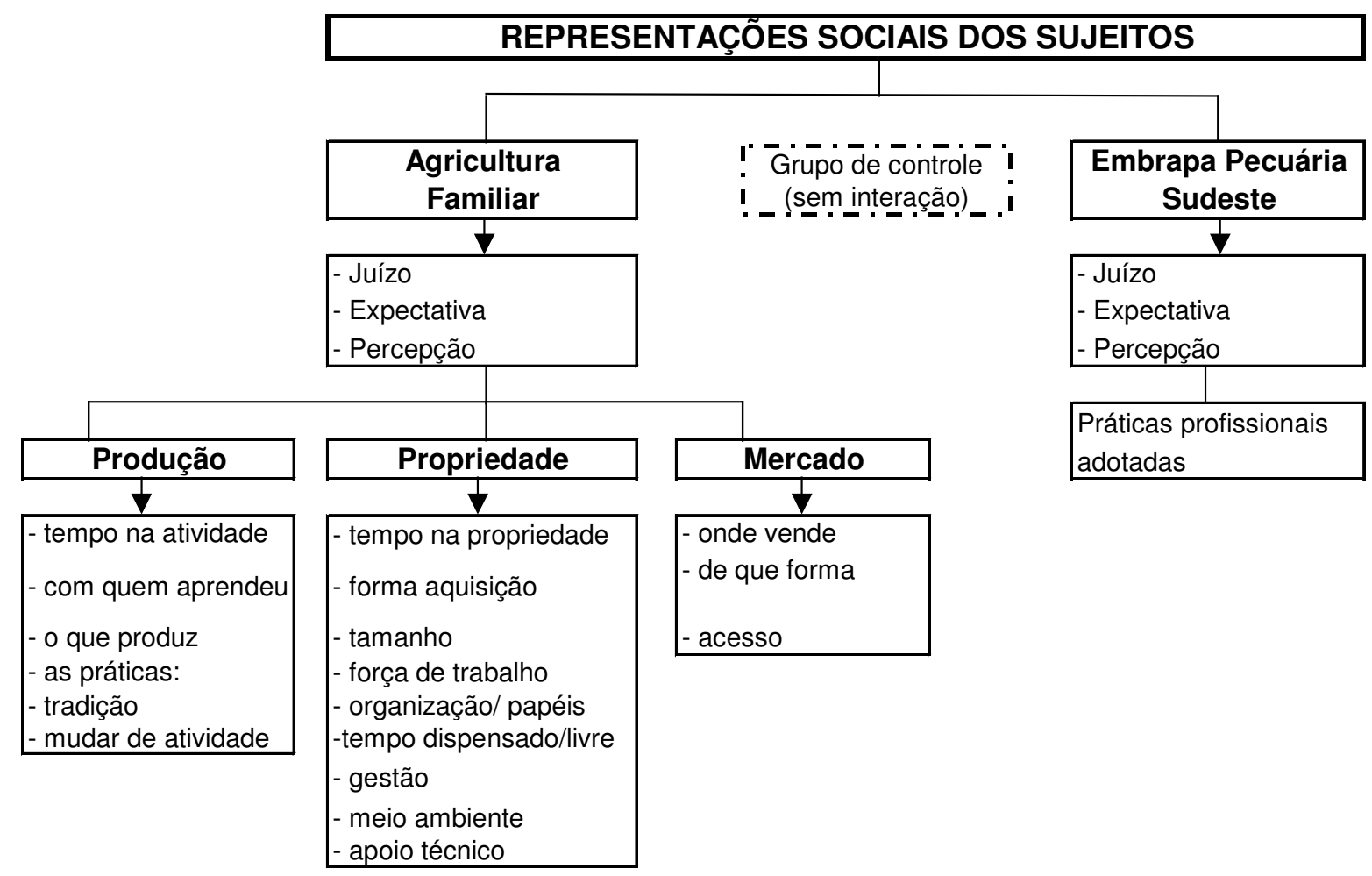

Figura 2: quadro esquemático do procedimento de análise

\subsubsection{O outro no olhar dos sujeitos envolvidos: apontando a qualidade das interações}

O espaço rural, hoje, apresenta características um tanto quanto diferente daquelas que estávamos habituados a descrever, qual seja, um lugar de isolamento. O fato é que o mundo globalizado fez deste espaço um universo socialmente integrado ao conjunto da sociedade brasileira e também internacional (Wanderlei, 2007). 
Embora, este novo cenário reduza a autonomia do mundo rural em relação ao conjunto da sociedade, o "(...) mundo rural mantém particularidades históricas, sociais, culturais e ecológicas, que o recortam como uma realidade própria (...)" (WANDERLEY, 2007:2).

Ora, se o lugar é onde os indivíduos interagem e se reproduzem materialmente e constroem seus valores, crenças, práticas etc.; ou seja, a sua identidade, mas ainda se faz necessário considerar as representações sociais a respeito desse lugar e, por conseguinte, dos sujeitos que ali interagem.

$\mathrm{Na}$ presente análise, conhecer as representações sociais que o sujeito da agricultura familiar tem em relação à instituição pública, que enseja interagir nos meios e modo de vida rural - seja ela a Embrapa, a CATI ou Secretaria de Agricultura - ou da instituição pública em relação à agricultura familiar, significa compreender as pré-disposições, os pré-juízos e os significados das experiências de aproximação.

No contexto da modernidade, o encontro desses dois sujeitos, evidencia a hegemonia do conhecimento técnico, sem, contudo, anular os aspectos de autodeterminação da agricultura familiar rastreados pela tradição; os quais se mantêm; muitas vezes, no rastro de tensões e conflitos com aqueles que induzem mudanças a qualquer custo. Tal confronto pode resultar em certo desprezo ou desdém entre um ou outro sujeito, ou entre ambos, quando da sua interação.

\footnotetext{
"A sugestão nossa é sempre procurar um técnico, nunca fazer um sistema desse sem o acompanhamento técnico, temos ene exemplos de gente que quebra a cara...Ele vai sempre depender de um técnico até ele andar com as próprias pernas".

(técnico C)
}

"Não tem visto muito não, benefício você tem é só a ajuda deles". (agricultor familiar A)

Contudo, fatores peculiares às unidades familiares, como, por exemplo, seu capital cultural, influencia as estratégias de reprodução material e na própria dinâmica social da agricultura familiar. Tais estratégias seguem, normalmente, uma racionalidade que se diferencia daquela exercida pelos técnicos, na qual predomina 
uma visão mercantil e empreendedora, enquanto que para o produtor estão voltadas para garantir sua sobrevivência e da família.

"Difícil, porque o cara [produtor] quer criar galinha e quer ter lucro dali, e quer criar galinha do jeito que o pai criava, o avô criava... E a coisa não é assim, hoje você tem que ser profissional".

(técnico F)

“(...) então, se o senhor [produtor] não quer se libertar disso, o que é que eu posso fazer... O senhor continue fazendo aí e que Deus tenha piedade da sua alma... ele não quer mudar!" (técnico D).

Carneiro (1999:327) explica que “(...) é necessário levar em conta a dinâmica interna, atribuída pelo próprio caráter familiar da organização social, que possibilita a essa forma social certa margem de autonomia na formulação das estratégias reprodutivas e na articulação com as condições externas".

A autora, considera que o núcleo familiar é que orienta e dá sentido às relações sociais e é nos seus processos interativos que ele cria, reproduz e reelabora suas práticas cotidianas de um fazer material e também das relações interpessoais. Para ela, “(...) a família também supõe um processo de individuação que pode negar, romper, modificar e, até mesmo recriar, valores num espaço de negociação e de tensões" (Id.: 327).

Essa racionalidade endógena da reprodução da família, algumas vezes, é percebida pelo técnico:

\footnotetext{
"Porque pela lógica do produtor familiar ele pode até complementar, ele tem aquela coisa da tradição do leite, do costume, do conhecimento de tirar leite que não é pra qualquer um". (técnico A)
}

Porém, isso não significa um consenso, pois, certas racionalidades técnicas ainda são balizadas por discursos que estão centrados nos padrões hierárquicos de poder, não aquele exercido por fatores econômicos ou de status, mas aquele advindo do saber científico. 
"Nosso aqui é colocado o cara [produtor] no cabresto e realmente o cara tem que ir naquela trajetória durante quatro ano e ai dele se pisar no buraco fora e aí ele está solto pra manga e a gente larga ele pra lá, mas quem ficar geralmente é bem sucedido...". (técnico C)

"Agora se a gente chega na visita e ele não fez silagem de milho e comprou feno; espere aí, mas a gente não combinou que ia usar o milho? Todo o recurso que ele ia adubar o pasto, plantar cana, investir em sombra... Ele comprou máquina, por que o senhor comprou uma máquina? Então, o senhor não está acreditando naquilo que a gente tá fazendo, então o senhor não precisa de ajuda...". (técnico B)

"Depois ele diz o seguinte: tem uma forma melhor de trabalhar, você quer produzir leite e ser feliz, ao invés de produzir leite e ficar reclamando da vida o tempo todo. Então tem um caminho" (técnico I).

Há, todavia, um contraponto no que diz respeito à postura dos técnicos. Estes, por sua vez, trazem em suas representações um conhecimento também produzido historicamente nas Academias e reproduzidos, na maioria das vezes, em suas práticas profissionais nas instituições para quem trabalham ou estão vinculados. Não existe aqui a pretensão de defender os técnicos, mas, uma análise sociológica, pressupõe um olhar distanciado a fim de melhor compreender o contexto.

O que se deseja esclarecer é que, assim como o agricultor familiar tem suas práticas balizadas na tradição, do patrimônio cultural e social e que lhes constituem um hábito; podendo ser, portanto, elementos de resistência à adoção de um modelo modernizante; também os técnicos constituem agentes intermediários de uma política, aqui, no caso, das instituições que os abrigam, especialmente as públicas, que obedecem a uma lógica racional empresarial existente no bojo da sua ideologia, dos seus produtos e das suas pesquisas, a qual, atualmente, se difunde, até, internacionalmente. A exemplo, tem-se a própria Embrapa, cujas relações já se estendem a países como a África e a Venezuela (EMBRAPA, 2006b).

O vínculo com a instituição pública atrela estes profissionais ao cumprimento de metas e compromissos formalizados em seus processos burocráticos como 
planos diretores, publicações técnicas, relatórios e projetos estabelecidos que, talvez, os tornem subordinados às demandas da instituição e menos compromissados em atender seu anseio profissional ou mesmo suas crenças.

"Treinar 350 profissionais da área de extensão rural vinculados ao projeto de transferência de tecnologias de produção de leite para agricultores familiares na região Sudeste" (EMBRAPA, 2005:36).

"Consolidar pelo menos dois canais de intercâmbio entre a Embrapa Pecuária Sudeste, seus públicos estratégicos e os atores sociais organizados" (EMBRAPA, 2005:36).

Sem contar que tais atendimentos à instituição, estão vinculados ao seu plano de trabalho e sujeitos à avaliação, ou seja, ele também é passível de pontos de acesso conflitantes com a instituição e pode não haver, de fato, um espaço para negociação.

Um trabalho desenvolvido pela Universidade Federal de São Carlos - UFSCar, em 2005, foi revelador de algumas tensões que envolviam as demandas da instituição e a dificuldade estrutural para cumpri-las; além de aspectos emocionais, especialmente àqueles relacionados à política de avaliação implantada na Embrapa (VALENCIO et al, 2005:45):

"O mesmo é dito em relação às demandas burocráticas, havendo um
forte controle interno, com excessivo gasto de tempo preenchendo
relatórios que pareceriam mais importantes que as pessoas e as
funções primordiais da Unidade".

Esta observação serve apenas para elucidar que as práticas dos técnicos não são algo que acontece fora de um contexto maior e que, portanto, podem ser representativas, também, de uma cultura de caráter institucional.

Ainda é preciso levar em consideração que, embora representantes da modernidade, os técnicos também são imbuídos de crenças, valores e sentimentos que podem denotar o desejo de contribuir para a melhoria da condição do outro, pois passam a acreditar que seus conhecimentos têm algo de "bom", benéfico ao indivíduo e por isso se torna contundente ao tentar persuadi-lo. 
É possível que acreditem estar contribuindo para o bem estar do produtor. No caso do projeto "Balde Cheio", alguns dos aspectos considerados positivos pelos técnicos e que expressam certa solidariedade, especialmente no que se refere à redução do esforço do agricultor no labor diário, bem como dos benefícios ao meio ambiente, são revelados nos relatos abaixo:

“(...) porque você acaba mudando o trabalho dele de cortar capim o dia inteiro, picar capim o dia inteiro, fazer trato o dia inteiro, esse trabalho foi reduzido ao mínimo com o uso de pastagem". (técnico B)

"Outra coisa é que uso menor de área implica em esforço menor do produtor em cuidar do seu rebanho, da saúde do rebanho... Também reduz esforço para o produtor".

(técnico I)

"Então a intensificação da produção leiteira... Ela é aliada da preservação ambiental ela não é a inimiga".

(técnico D)

“(...) o conjunto da técnica permite que ele consiga adotar a legislação ambiental porque sobra área... $O$ extensivo não permite isso.

(técnico G)

Tal reconhecimento, entretanto, não significa isentá-lo da responsabilidade de, quando da interação com o "outro", com o qual deseja estabelecer relação, atentar para a necessidade de considerar as várias facetas que o processo comunicacional apresenta e que contribuem para a eficiência e eficácia da dialogicidade.

É salutar, então, reconhecer que para alcançar êxito em tal processo, significa compreender o universo de pluralidades de conhecimentos distintos aí contidos e que transcende o conhecimento científico. É importante perceber que o "lugar" da interação é uma "ecologia de saberes", que lhe confere uma interação sustentável sem comprometer a autonomia das partes, ou seja, "(...) baseia-se na idéia de que o conhecimento é interconhecimento" (SANTOS, 2008:24). 
A hierarquização das relações do técnico com o agricultor, não ocorre apenas na interação presencial, mas deriva de um processo classificatório e de avaliação processual das condutas que são paulatinamente burocratizados.

\footnotetext{
"Estratégia de ação tem que ser organizado e saber gerenciar essas atividades, tem as fichas, planilha de custo isso tudo tem que estar tudo certinho, anotadinho se não ele não consegue avaliar, não consegue tomar a decisão correta ou a menos errada... Se ele não se adequar, ele será cortado".

(técnico D)

"Depois que ele entra, acho que não, inclusive isso é uma exigência né? Do projeto né? É exigência, a cada quatro meses passou lá se a anotação não tiver feita é tchau pra você, se não for dessa forma não tem como dá certo".

(técnico F)
}

Uma das formas pelas quais o poder exercido sobre os sujeitos, deixa de ser algo coercitivo e passa a ser legitimado pelos mesmos, é aquela na qual os produtores supõem que o capital cultural do técnico, respaldado pelo conhecimento formal, parece algo intrinsecamente bom:

"Eles me explicam, se a gente tiver alguma dúvida, eles explica, dá assistência, o que a gente tem que fazer, porque tem muitas coisinhas que a gente não sabe né? Então pelos estudos dele, eles ensinam a gente é muito bom!".

(agricultor familiar $\mathrm{C}$ )

"Olha eu vi que eles eram muito meu amigo, sabe. Eu sabia que eles não tava me empurrando pro buraco eles queria me ajudar mesmo...".

(agricultor familiar E)

Todavia há os agricultores que mostram os limites de aceitação do conhecimento técnico. 
"Trabalhar em cima de um bom pastejo pro gado, bom volumoso vamos dizer na época das águas e na seca, ter uma boa qualidade de volumoso que o [técnico] fala muito da cana. Só que eu não concordo muito com ele, só a cana. Eu quero o silo".

(agricultor familiar D)

A contrapartida à submissão do produtor é o olhar desqualificador das condições materiais prévias que o contexto sócio-econômico rural proporciona:

"Tem que fazer dinheiro do lixo que ele tem... aí ele vai comprar calcário, arame, análise de solo...”. (técnico G)

O fazer cotidiano da agricultura familiar não tem uma rotina burocrática; tem, por um lado, uma complexidade própria, nas muitas tarefas; por outro, imiscui ao trabalho público e privado, a labuta e o descanso:

"Eu tiro esse leite e ainda vou pro café né? Faço muito serviçinho de café, faço serviço de quintal, que é uma coisa e outra, arruma uma cerca...".

(agricultor familiar B)

"Eu faço de tudo, faço porteira, capino café, faço de tudo um pouquinho...".

(agricultor familiar E)

Em primeiro lugar, o espaço rural é visto enquanto espaço físico diferenciado daquele que atravessa a rotina de laboratório de pesquisa. Enquanto as tarefas de tirar leite, arrumar cerca, cortar cana, juntar esterco, apanhar café etc, pode constituir-se tarefas de um mesmo trabalhador no campo; os técnicos, por sua vez, têm uma visão sistematizada e racionalizada das atividades a serem desempenhadas.

Daí porque, quando tais técnicos avalisam, parceladamente, a eficiência do trabalho rural, muitas vezes diagnosticam baixa produtividade, atraso etc, sem considerar o arcabouço de conhecimento que há nesses múltiplos fazeres. 
A análise desse item permitiu a compreensão acerca dos juízos, valores e expectativas que permeiam a interação dos grupos envolvidos. Para o agricultor familiar a instituição pública representa aquele que vem de fora em forma de "ajuda"; mas não determinará suas ações, pois prevalece a este grupo o valor da autonomia na execução do seu pensar e fazer, embora reconheça a importância da instituição pública.

Enquanto que para os técnicos, o "outro" será sempre aquele incapaz de realizar-se por suas próprias práticas e saberes, relacionam a condição de bem estar do produtor se este incorporar o "moderno" às suas rotinas, o qual the conferirá conforto e estabilidade, sendo a condição única para assegurar a sua própria identidade de produtor. A forma de perceber o agricultor parece manter-se como sempre foi visto na história, ou seja, o homem do campo deve aceitar, mecanicamente, aquilo que o homem "superior", com seu conhecimento técnico, Ihe oferece, para transformá-lo em "moderno" da mesma forma que ele se enxerga moderno.

Tais reconhecimentos sugerem uma aproximação relativa entre os grupos, com pontos de acesso ainda a desejar; no qual, não ruma para uma dialogicidade, fator indispensável à proposta de sustentabilidade.

O grupo de controle revelou certa indiferença à instituição pública, não significa, entretanto, desprezá-la, mas não a percebe como alternativa, como fonte de novas possibilidades para sua atividade. Desta forma, este grupo se aproxima das percepções do grupo em interação.

"A Embrapa que a gente tem os conhecimentos, ela sempre fica pesquisando as coisas, desenvolver projeto pro Brasil" (agricultor familiar E - sem interação).

"Ela [Embrapa] vem aqui no meu vizinho, ela vem... tem umas reunião de piquete, explicando pra plantar cana, cuidar do gado, se a pessoa tirar 300 litros de leite se ela quiser tirar 800, dá orientação". (agricultor familiar C - sem interação)

"Eu pensava que a Embrapa prestava assistência técnica aos produtores...".

(agricultor familiar A - sem interação) 
Tais representações transitam não somente no nível das idéias, mas também de suas práticas, conforme discorreremos no próximo item.

\subsubsection{A produção material do agricultor familiar: valorização ou depreciação?}

Neste item pretende-se, analisar de maneira integrada os indicadores produção, propriedade e mercado. Esta análise consubstanciada é pertinente uma vez que, na dinâmica da produção material da unidade familiar, estes indicadores são tão imbricados que a melhor forma de explicá-los é costurando uma reflexão conjunta.

Nas últimas décadas, pode-se observar que os espaços rurais dedicados à agricultura passaram por um grande processo de transformação: “(...) perderam a autonomia relativa que possuíam e se integraram econômica, social e culturalmente à sociedade 'englobante'” (WANDERLEY, 2007:93).

Tais transformações, especialmente de ordem econômica, provocaram mudanças significativas na forma de produzir (ainda que algumas práticas tradicionais persistam) às quais foram sendo pressionadas para uma crescente modernização visando o aumento de produtividade e integração ao mercado, sobretudo o mercado externo. Ao perseguir tais propósitos, as políticas adotadas priorizaram a busca do aumento da eficiência deste segmento econômico, a partir da implantação de um modelo produtivista, cujo alicerce era “(...) a adoção de sistemas intensivos de produção e a crescente integração à complexa economia de mercado" (WANDERLEY, 2007b:93). Ao lado dessa preocupação, surgem aquelas de caráter ambiental, que vêem na agricultura familiar uma possibilidade de síntese entre os interesses do mercado e a garantia de uma conservação dos recursos biótico e abiótico que, por sua vez, é próprio do olhar da tradição sobre a natureza.

Ao tomar, como pano de fundo, a partir de um microrrecorte, o cenário exposto, encontramos a Embrapa Pecuária Sudeste, por meio do projeto "Balde Cheio", o qual, em termos da produção econômica objetiva "(...) mostrar a viabilidade técnica e econômica da produção intensiva de leite (...)", em estabelecimentos familiares, por meio das técnicas do uso intensivo de pastagens, melhoramento genético, controles reprodutivo e sanitário, entre outros e, em termos ambientais, preocupa-se em melhorar as condições de fertilidade do solo, plantio de matas 
ciliares e melhoria da qualidade da água e, de gestão, os controles zootécnico, das receitas e das despesas (EMBRAPA, 2004: 1).

No projeto em questão, uma das propostas para obter êxito em parte das recomendações, diz respeito à irrigação. Ainda que não seja uma prioridade, ela é considerada mais uma ferramenta moderna que potencializa os resultados desejados pelo projeto, qual seja, o uso da pastagem "natural" por um período maior com vistas a diminuir custos, além de ser uma maneira de enfrentamento às condições ambientais do momento (período sem chuvas).

Nesta proposta de modernização das práticas, para a produção de leite, está presente uma racionalidade, organização e sistematização que são próprias da modernidade. Embora, no discurso institucional, não seja exigida uma seqüência linear de procedimentos (como as produções em série observadas nas indústrias), pressupõe adotá-los em seu conjunto, na sua totalidade.

$\mathrm{Na}$ interação do agricultor familiar com o conhecimento perito, a subordinação do primeiro é ensejada por um elenco de fatores, desde o rol de especificidades e burocratização que passam a exigir ajustamentos até as ameaças de ruptura à violência simbólica, expressa pela opinião do próprio agricultor familiar acerca de sua incapacidade e atraso.

"O pacote que é passado para o técnico [da extensão] até chegar aos produtores é um conjunto de tecnologias que tem que aplicar, que passa pelo manejo do rebanho, pastagem, controle sanitário, controle da alimentação, nutrição, controle zootécnico, gerencial, controle de custos, receita conjunto de tecnologias que é implantado na propriedade (...)".

(técnico $\mathrm{E}$, grifo nosso)

“(..) fazer sempre o que foi combinado e fazer as anotações básicas (clima, dinheiro e gado). Se não cumprir será eliminado... Não sou eu que vou consertar o mundo, isso não é um projeto de assistência social é de cunho social (...)".

(técnico D, grifo nosso)

“Igual ele [técnico] quer planilha de custo, de leite tudo... minha parte eu faço. Mas, é uma papelada que cada vez eles [técnicos] foi 
bagunçando mais... Então foi... eu acho que eu saio do projeto por causa disso, minha parte eu fiz".

(agricultor familiar C, grifo nosso)

"Desde que você entra no projeto, você tem que acompanhar, no projeto aí o [técnico] corta, quem tá e não faz o que é combinado, ele vira as costas e vai embora, isso aí ele [técnico] já cansou de falar...".

(agricultor familiar A, grifo nosso)

"Inseminação ainda não estou fazendo, sei que é um erro meu, é uma briga do pessoal da Embrapa, da [cooperativa], que eles falam que eu estou atrasado (...)".

(agricultor familiar $\mathrm{B}$, grifo nosso)

As condições de produção agropecuária dadas pela técnica, exigem um novo modelo de agricultor que opere numa lógica empresarial:

"Estes teriam como principais características a aplicação, pelas
empresas rurais, de "estratégias empresariais complexas", entre as
quais, o exercício da função comercial, juntamente com a função
produtiva, obrigando o agricultor a adquirir uma competência no que
se refere, sobretudo, à gestão de seu empreendimento e ao controle
de um sistema que associa diversas atividades" (WANDERLEY,
2007:121).

O poder hoje é tecnológico e utiliza suas ferramentas para exercer seu controle sobre nossas rotinas e práticas. Contudo, segundo Giddens (1991:45), “(..) mesmo na mais modernizada das sociedades, a tradição continua a desempenhar um papel”.

No caso da agricultura familiar, esta tradição se reflete, em muitos casos, no valor que a autodeterminação tem na condução de algumas de suas práticas o que faz com que este sujeito resista às imposições da modernidade, tal como encontramos.

"Porque o homem lá da Embrapa, aí tem os piquete, todo dia as vacas come nas águas, comeu essa noite, vai lá taca o adubo e ali 
amanhã não vai, até que vai chegando os piquetes, mas eu não tenho área pra esse tanto piquetes, 30 piquetes. As áreas melhor que eu tenho, eu planto cana, prefiro fazer isso, é um sistema bom pela minha idéia, pela minha idéia..." (agricultor familiar $\mathrm{C}$ ).

Os discursos apresentados, sinalizam uma tendência a atribuir valor menor às práticas desenvolvias pelos agricultores familiares, na tentativa de convencê-los da necessidade de incorporar novos fazeres que a técnica sugere.

\subsubsection{As práticas de produção: dimensões objetivas da resistência e assimilação da inovação}

Se as medidas modernizadoras sobre a agricultura familiar estão sendo moldadas no padrão de produção que estimula o aumento da produtividade, crédito agrícola e a introdução de novos produtos na agenda de produção, seus efeitos sobre os sujeitos local e a maneira como ele enfrenta tais desafios, não são uniformes pois, dependendo das particularidades de cada produtor, elas produzem efeitos diferenciados devido à heterogeneidade dos aspectos culturais, sociais e econômicos desse sujeito (WANDERLEY, 2007).

No universo de agricultores familiares pesquisados neste trabalho, observamos uma ambigüidade nas suas práticas produtivas, às quais se misturam tradição e modernidade, por conta daquilo que, possivelmente, Giddens (1991:95) chamou de "segurança ontológica": "A expressão se refere à crença que a maioria dos seres humanos tem na continuidade de sua auto-identidade e na constância dos ambientes de ação social e material circundantes".

"Ele [silo] é mais caro e eles [técnicos] trabalham muito em cima de custo menor e a cana o custo é menor, só que eu acho o silo um volumoso mais forte. Hoje eu dou o silo e a cana".

(agricultor familiar D)

"Pra entender como tudo isso funciona, o produtor pode demorar e ele pode ter medo, e pode querer voltar à condição inicial, porque era menos perigoso, porque ali ele estava seguro, ele não tinha nada, mas pelo menos ele sabia que não tinha nada, sabia como ele sobrevivia". 
(técnico I)

O conhecimento técnico não tem como atrelar as técnicas novas a um nível de segurança equivalente ao da tradição, posto que o que repousa na modernidade é a constante mudança:

"Se hoje o pacote tecnológico é esse que está sendo apresentado, amanhã, depois, o pacote pode ser outro (...)".

(técnico I)

ou, conforme Giddens (1991:51): "A reflexividade da modernidade, que está diretamente envolvida com a contínua geração de autoconhecimento sistemático, não estabiliza a relação entre conhecimento técnico e conhecimento aplicado em ações leigas". Todavia, é a acumulação em bases plenamente capitalistas, que se coloca como o risco aceitável para alguns produtores na adoção das técnicas que Ihes são oferecidas pela Embrapa.

É na transição de um modelo - ou na resistência ou síntese precária - para o outro, que vê-se o produtor adotando, concomitantemente, técnicas como o uso do latão e o tanque de expansão (foto 8).
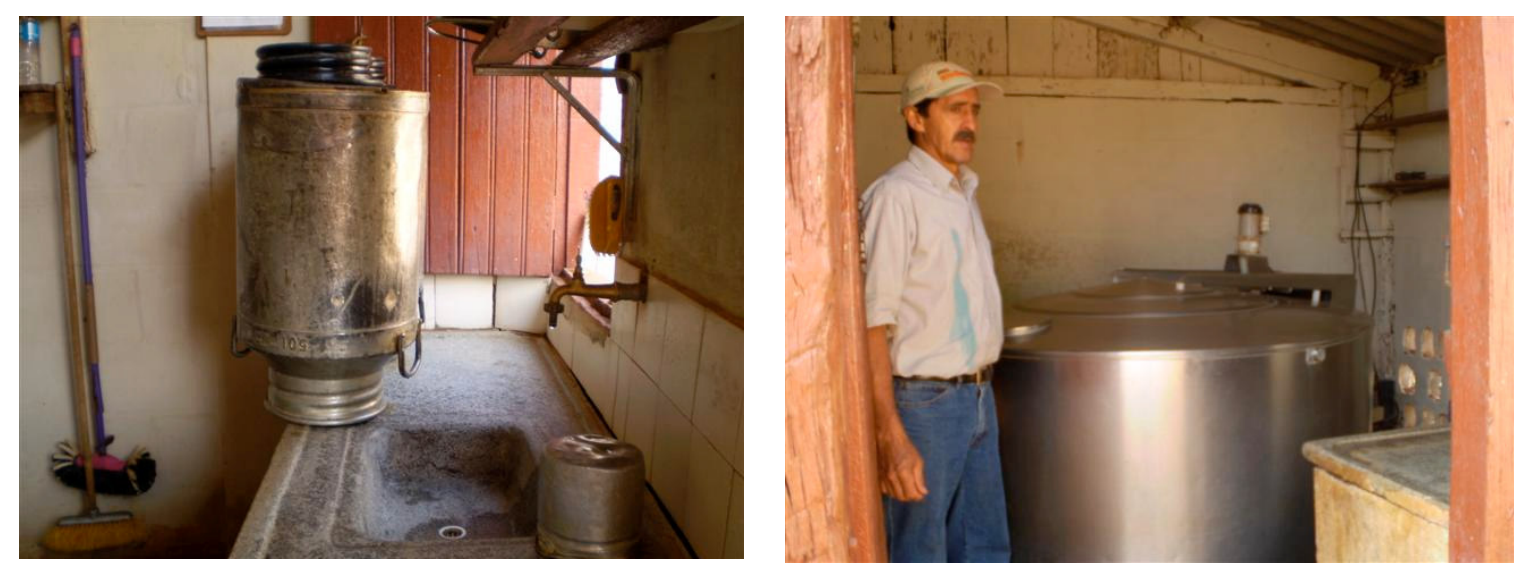

FOTO 8: uso do latão (tradicional) e o resfriador (moderno) para acondicionamento do leite.

Porém essa ambigüidade não é bem assimilada pela Embrapa uma vez que a inovação tecnológica apresenta-se como um "candeeiro" a iluminar o caminho que livra o produtor do atraso e morte social. 
"Ela [a técnica] rompe de uma maneira bem visível a maneira tradicional, mas o rompimento se dá por uma necessidade do produtor, o produtor está acuado, ele está com uma área pequena, o solo está desgastado, tá cansado, ele não tem produtividade, ele não tem alternativa e de repente, aparece um tipo de alternativa (...)" (técnico A)

"Viabilizar, primeiro a permanência do produtor em condições dignas, se eu pudesse resumir em poucas palavras seria isso, viabilizar a permanência do produtor no campo em condições muito dignas, ou seja, você tem que dá pra ele de volta a autoestima que ele perdeu (...)".

(técnico I)

A inovação é uma condição ofertada ao produtor o que, no âmbito das interações, sinaliza que sua não adoção sujeita o produtor ao fracasso enquanto tal. Ele é estimulado pelo técnico a realizar esta prática, pois passam a ser convencidos de que tal opção é uma necessidade, o que lhe exige uma renúncia dos seus fazeres nas bases tradicionais e um novo aprendizado.

"Por exemplo, eles [técnicos] estão batendo aqui em casa que tem que irrigar, tem que irrigar... Eu falo minha água não dá, eles vão olhar fala sua água sobra... Então, é assim, é mais uma briga que nós estamos tendo que, se Deus quiser, vai chegar onde chegou todas as outras: que é irrigar (...)".

(agricultor familiar B)

"Para aumentar a produtividade pra isso a gente usa a pastagem e diminuindo custo... e utilizamos a irrigação para ampliar o tempo de utilização do pasto em relação ao cocho".

(técnico D).

Enquanto o processo de convencimento do produtor está em curso, na reflexividade institucional campeiam dúvidas entre os técnicos. 
"Por exemplo, a irrigação, irrigação é uma coisa questionável até no meio científico, eu, por exemplo sou contra irrigação de pasto... Então, quando você considera um recurso escasso num estado que... São Paulo vai buscar água lá no sistema Cantareira, quer dizer é caro você fazer isso, pra uma coisa que a eficiência biológica não é tão alta... Não sei, eu tenho muitas dúvidas sobre irrigação de pasto". (técnico $\mathrm{H}$ )

Os riscos também são considerados pelo meio técnico, mas as estratégias de convencimento ao produtor podem passar ao largo disso, na medida em que a comprovação em bases experimentais não tenha se realizado.

"Ele [esterco] pode ser risco, os trabalhos que o [pesquisador] tem
aqui na fazenda não mostraram isso, mas você tem risco de
lixiviação de nitrato para lençol freático, isso é risco pra saúde
humana, você pode ter adubo sendo carregado pela chuva pra fossa,
uma lagoa, e você começa um processo de eutroficação etc."
(técnico H)

No contexto atual, onde a informação é algo que circula com uma velocidade considerável, alguns produtores que não fazem parte do projeto "Balde Cheio", também passam a acreditar na necessidade de adotar a irrigação, supondo que ela possa representar a viabilidade e a garantia da sua reprodução material, no que diz respeito à subsistência da sua família por um tempo maior (foto 9).

"Minha intenção é adubar e irrigar... Mas como a área ficou pequena, eu tenho que procurar fazer isso, porque pra poder dá mais tempo lá no pasto, ele vim melhor... porque agora se eu tivesse aguando podia ter até algum pastinho...".

(agricultor familiar $\mathrm{A}$ ) 


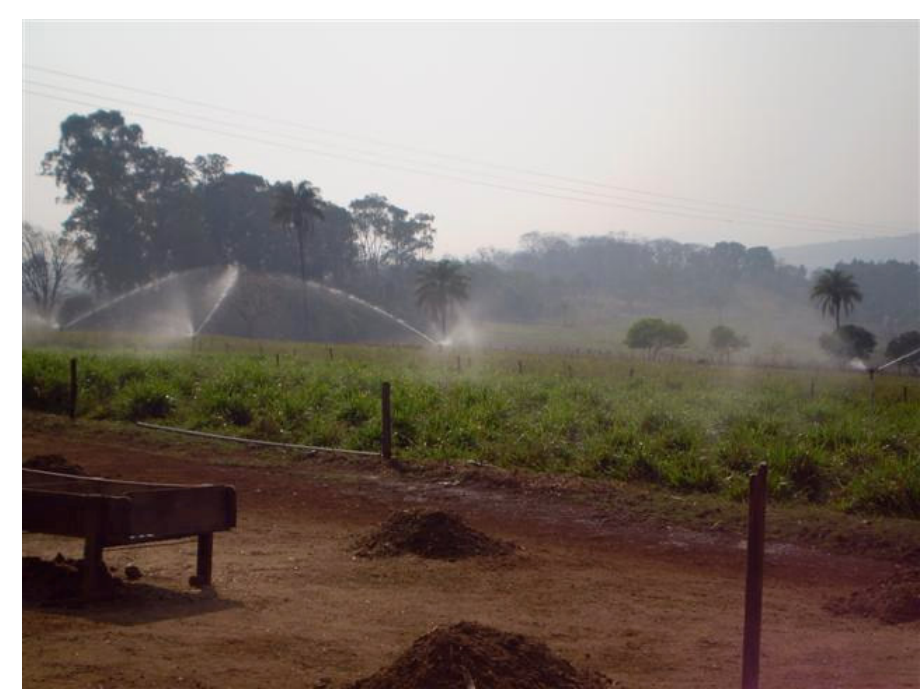

FOTO 9: área de irrigação de capim feita conforme recomendação da Embrapa ao produtor.

Em alguns aspectos, a menor resistência do produtor deve-se à relativa familiaridade com as técnicas apresentadas em roupagem moderna. Entre elas a formação e adubação de "piquetes" (demarcação de pequenas áreas dentro da propriedade). Essa é uma tecnologia antiga, o que o projeto fez foi agrupá-las de maneira sistemática. Porém, essa é a razão mesma, pela qual, o produtor pode prescindir do técnico para levar adiante sua própria experimentação.

Diante de uma sociedade moderna e globalizada, na qual a informação circula facilmente, não é difícil que o produtor a tenha conhecido por outras vias que não seja a partir da instituição pública; pode ser por meio de revistas, publicações ou, até mesmo, a partir do seu vizinho.

\footnotetext{
"O piquete vou fazer pra umas 20 vacas. As outras 20 eu vou ter que vender algumas, eu quero assim melhorar, tirar um pouco de gado, e por mais vaca e procurar melhorar a comida dela pra dá mais leite... Mas, primeiro eu vou andar, vou ver, tirar alguma experiência, ver quem tá dando certo (...)".

(agricultor familiar A - sem interação)
}

"Sobre os piquetes, há um tempo atrás eu comprava a revista da Parmalat, sempre tinha uns projetos de piquete, eu gosto de ficar pesquisando...".

(agricultor familiar E - sem interação) 
Mas, render-se à tecnologia por meio do contato formal, exige confiança, auxílio e cooperação:

"Eu acho que eu faço, se tiver alguma ajuda é melhor, né? Mas eu vou tentar fazer... Aqui na região que eu sei que tá fazendo é a [cooperativa]... Não, mas eles sempre cobram, fala que vai ajudar, ajudar nada no fim cobra isso, cobra aquilo, acaba saindo caro". (agricultor familiar A - sem interação)

No processo de produção leiteira, a ordenha mecânica e o tanque de resfriamento são equipamentos que expressam o que há de mais moderno (para a condição da maioria dos agricultores familiares), no sentido de minimizar os riscos de contaminação do leite e, conseqüentemente, otimizar a segurança alimentar. Porém, concomitante ao uso deles, produtores em interação no projeto "Balde Cheio", mantêm uma das práticas mais antigas como a de amarrar o bezerro ao pé da vaca e a venda do leite em latão, que são práticas tradicionais.

"Na ordenha eu tiro com bezerro ao pé ainda, meus bezerros ainda mamam... Eles já tentaram abolir no caso aqui em casa, tirar, mas é o caso, tem muitas coisas que eu ainda vou chegar, então eu falo paciência... que nós vamos chegar lá".

(agricultor familiar B).

"Eu vendo sozinho, eu vendo leite em Franca, só que é quantidade maior, pra fazer pão de queijo, em latão, sorveteria também". (agricultor familiar C)

Outra prática tradicional observada foi o uso do jornal para enxugar o úbere da vaca. Embora a orientação seja o uso de papel toalha descartável, o fazer enxugando com jornal é comum e recorrente (foto 10).

"Então, põe pra mamar, acabou de mamar eu passo o jornal, um papel toalha, um papel descartável, depois eu ponho a teteira". (agricultor familiar B) 


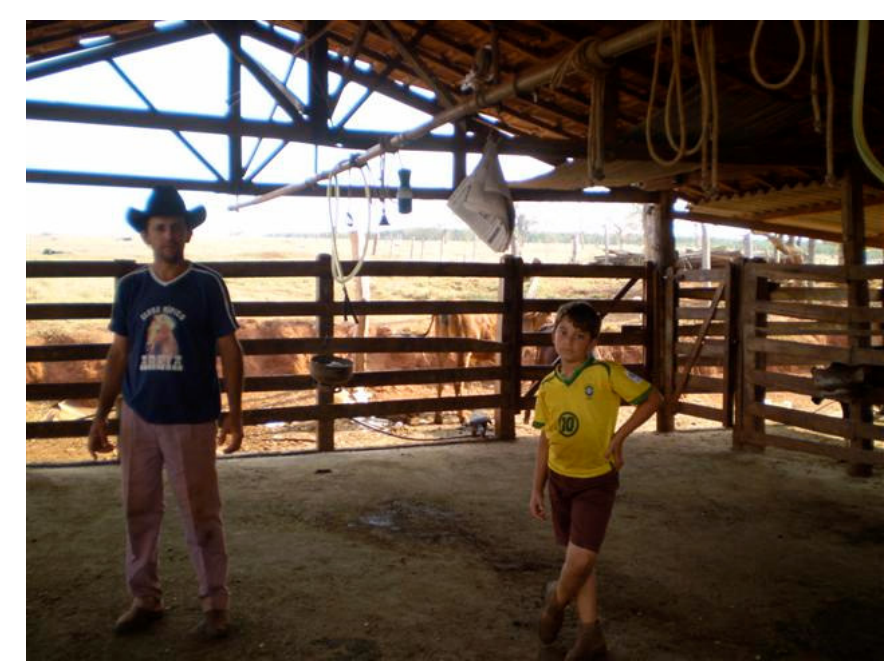

FOTO 10: folhas de jornal presas ao suporte do equipamento da ordenha; é usado para secar o úbere da vaca antes da ordenha.

A persistência de tais práticas retira parcela da efetividade do controle sanitário dos procedimentos produtivos e tais ambigüidades, que também revelam os riscos da manutenção de práticas tradicionais, é algo que exige a busca de novas sínteses, mais sustentáveis.

\subsubsection{A propriedade familiar como produção social do lugar}

A propriedade familiar constitui-se um lugar no qual a família desenvolve suas relações públicas e privadas de trabalho, de afetividade e de integração com seu entorno.

Conforme anunciado por Santos (1992), é preciso diferenciar lugar de localização, pois em função das dinâmicas sociais, o lugar continua como um ponto geográfico, mas a localização tem sua função modificada pelo movimento das relações e interações na sociedade; isto atribui ao lugar novos significados e novos sentidos. Por isso, o espaço rural pode estar, bem ou mal, definido geograficamente, mas suas funções sofreram mudanças no processo de modernização da agricultura.

Para o agricultor familiar, o espaço rural, seu lugar de residência, ainda mantém as mesmas características, ou seja, é o espaço de trabalho, moradia e sociabilidade. Contudo, não se pode dizer que atende apenas à função de produzir alimentos, ao contrário, hoje ele também é um espaço de entretenimento, turismo rural, preservação do meio-ambiente, a manutenção do patrimônio cultural do campo etc, que, na literatura, julgou-se chamar de multifuncionalidade (MALUF, 2002). 
Maluf (2002) considera fundamental as relações estabelecidas pelas famílias rurais em seus territórios, nos quais as dinâmicas ocorridas diferem de regiões ou localidades e contribuem para a conformação dos mesmos.

Neste trabalho, os produtores entrevistados possuem uma relação com a propriedade muito além da dimensão econômica de mercado. Trata-se de um locus que permite aflorar o sentimento de pertencer e a identidade social do grupo, pois na sua grande maioria, constitui um patrimônio de herança, no qual estão presentes suas lembranças de família, no que inclui suas práticas agropecuárias.

"A propriedade nossa tinha 85 alqueires, eu tirava leite com meu pai, tirava leite 70-80 litros, na época o gado era bom, já tinha formação de pasto, mas uns piquetes um pouco maior, nós tirava leite de umas 60 vacas nesses piquetes, e meu pai tinha um pouco de gado de corte, sempre já foi, meu pai a idéia dele já era, ele sempre gostava de ver o gado bonito e bem alimentado, então sempre a gente tratou".

(agricultor familiar A)

"Meu pai dividiu e meu sogro dividiu, faz 12 anos que meu pai dividiu e faz 10 anos que meu sogro dividiu... Primeiro ela [esposa] morou nessa casa, aí quando eu vim eu tirei ela daqui pra mim morar, só que eu já tava de olho nela [na esposa]".

(agricultor familiar E)

Daí, talvez, possa se explicar a ambigüidade vivida pelo produtor. Ao mesmo tempo em que precisa adotar práticas mais modernas para garantir a reprodução social, ele também mantém um fazer tradicional como reafirmação da memória da família, o que permitiu aos seus antecessores sua própria sobrevivência.

Contudo, a racionalidade técnica desconsidera tais significados para sobrepor aos mesmos um dado rigor no controle e organização dos processos, induzindo a dissolução de hábitos dos quais ele não deseja se desprender.

"Eu não queria passar, eu não abro [mão], desculpa é uma ignorância minha. Pra mim eu fazia, toda vida eu fiz. Fazia da minha forma... Então eu falava: não, eu tenho do meu jeito e o meu jeito era 
certo e até batia com o deles, mas eles tinham o modelo que eles queriam lá do computador, conforme eles queriam por".

Quanto eu ganhei eu sabia, quanto me custou eu sabia, quanto eu tava ganhando eu sabia, como eu podia é... eu marcava tudo, eu tenho esse controle faz desde que eu mexo nós tem esse controle, isso vem do pai. Nós tem esse controle anotado, guardado, num caderninho"

(agricultor familiar B)

"Já tem no projeto aí já fizeram, mas nós achava que o poço não dava conta de irrigar, então eu disse deixa de mão...".

(agricultor familiar A).

Sobre a memória, passam a proceder o cálculo, o letramento, a lógica empresarial (Foto 11).

"A anotação é fundamental, porque se não, como você vai gerenciar uma empresa se você não tem dados? Como vai avaliar se aquela atividade é presta ou não presta, se é boa ou ruim? Por isso essa é uma condição básica... Se ele falhar nisso, ele está fora!". (técnico D)

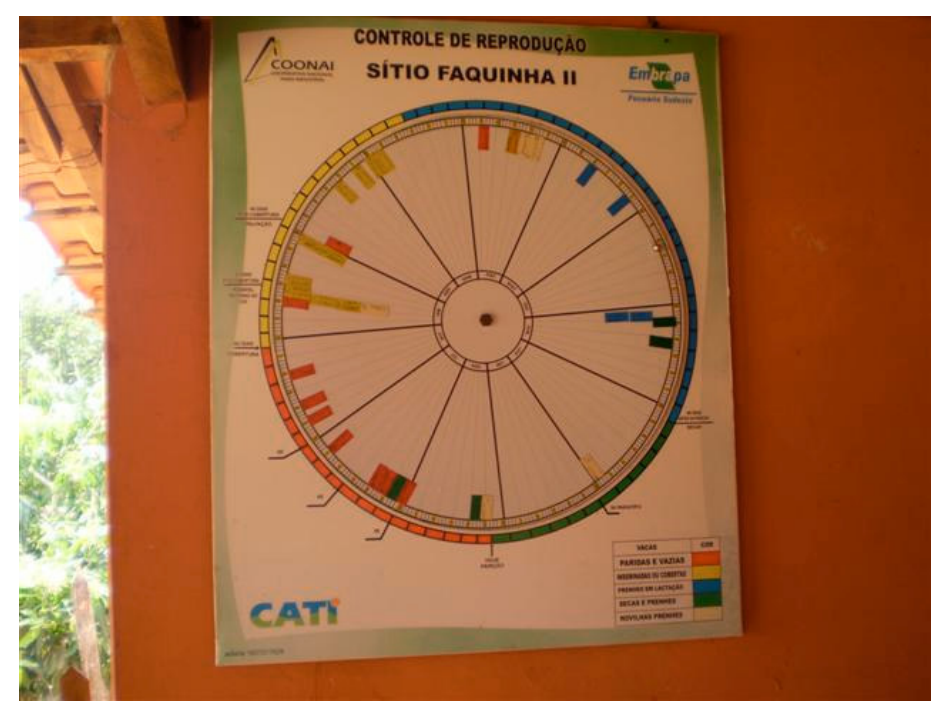

FOTO 11: quadro técnico para anotações afixado na parede da casa do produtor participante do projeto. 
Embora as políticas agrícolas de um passado recente tenham engendrado severos impactos ambientais - como ainda assistimos na monocultura - os programas e projetos em curso, voltados para a agricultura familiar, demonstram relativa preocupação com a questão, recomendando práticas que desacelerem o ritmo da degradação ambiental.

Programas como o de Microbacias, é uma delas, o qual tenciona a práticas de conservação dos recursos naturais por meio da proteção de nascentes, formação de mata ciliar, curva de nível, reflorestamento, entre outras.

No entanto, é no dia a dia da propriedade que se pode verificar o quanto as novas práticas recomendadas pelos técnicos e adotadas pelas famílias rurais podem ter sustentabilidade.

No caso do projeto "Balde Cheio", os efeitos sobre o meio ambiente, segundo os sujeitos envolvidos, são o de recuperação e melhoria das condições do meio ambiente.

"Que tem ganhos ambientais, sem dúvida, quando a gente substitui pastos degradados por pastos de alta produção, isto tem um ganho ambiental muito grande. Porque você protege o solo, você evita lixiviação nutrientes, erosão, você recuperação de fertilidade, você volta com a vida do solo, então são técnicas que realmente acabam protegendo o meio ambiente".

(técnico B)

"O conjunto da técnica permite que ele consiga adotar a legislação ambiental porque sobra área... $\mathrm{O}$ extensivo não permite isso". (técnico G)

"Contribui, assim você tá corrigindo o solo, faz curva de nível, tá ajudando nessa parte né?"

(agricultor familiar C)

Contudo, os riscos, as contradições e a constante reflexividade no âmbito da instituição moderna, podem gerar divergências entre conhecimentos técnicos, recorrentes, o que coloca no interior do sistema perito incertezas que extravasam para a relação com os produtores como se fossem certezas categóricas. 
"Então, pode ter algum problema, você teria, por um lado os benefícios que seria a recuperação do pasto, do solo e a possibilidade de usar áreas menores o que libera área para mata ciliar etc, por outro você tem a questão do insumo, que é externo que é grande que você tem esses riscos de lixiviação de levar isso pra corpos d'água e tem esse problema do esterco".

(técnico H)

O que se observou é que já existe, por parte dos agricultores familiares, tanto àqueles que mantêm vínculo com o projeto "Balde Cheio", quanto àqueles que não o têm, uma preocupação com os problemas ambientais, muito mais pela iminência punitiva na aplicação da legislação ambiental, pelos agentes da fiscalização, do que propriamente pela consciência da necessidade de adoção da técnica.

Entretanto, a recuperação do pasto, aparece como um resultado da técnica diferenciador entre os agricultores familiares em interação com a Embrapa e os que se mantém sem interação na região estudada.

Não se pode negar, todavia, que exista também, por parte do agricultor familiar, um desejo de cuidar do que venha do sentimento de proteger aquilo que é seu patrimônio familiar e que servirá a gerações futuras de sua família (Foto 12).

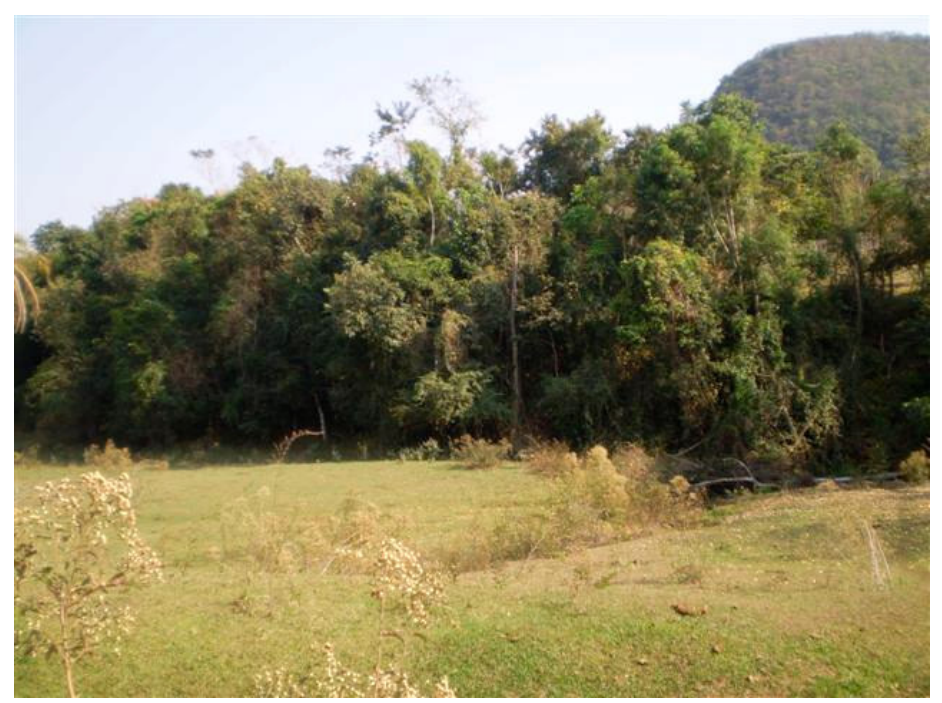

FOTO 12: local da nascente na propriedade do agricultor familiar, protegida por uma vegetação nativa.

Todavia, a preocupação com a preservação de parte da área não coincide com aquilo que o arcabouço legal recomenda, de modo que as instituições ambientais, 
também colocam restrições severas à reprodução social da agricultura familiar, devido ao tamanho da propriedade e sua relação com as necessidades de produção:

\footnotetext{
"Beirada de córrego, a beirada a gente sempre nós cuidamos, sempre nós tivemos essa consciência. Nós ainda não tá realmente $100 \%$ na lei, porque nosso sítio é muito pequenininho, se nós for tirar muito a área nós vamos perder muita terra (...)".

(agricultor familiar B)
}

"Só que agora essa micro bacia, eles mediram pra mim, vai pegar um alqueire, porque tem muita água. A única coisa que eu não sou de acordo, é essa micro bacia, o governo pegar esse tudo de terra (...)".

(agricultor familiar G - sem interação com o projeto)

$\mathrm{Na}$ visita em uma das propriedades, um dos entrevistados mostrou-se preocupado com a presença dos fiscais que naqueles dias, soube ele, encontravamse nas redondezas. A água da sua propriedade é oriunda de poço artesiano e ele estava montando a estrutura de irrigação em atendimento à recomendação do projeto e temia ser multado pelos fiscais. Para a situação descrita, a observação direta da pesquisadora é que permitiu perceber a significativa apreensão do produtor com a situação, numa expectativa de que seria penalizado apesar de estar se modernizando. Ou melhor, porque os requerimentos de aumento de produtividade (via irrigação) fossem incompatíveis com a oferta hídrica, como se a instituição perita em agropecuária, que direcionou-se para uma prática que a instituição perita ambiental, caracterizasse, eventualmente, como degradadora da natureza. A qual delas, porventura, atendeu para o dilema que o produtor antecipava em sua angústia mal encoberta?

O potencial da agricultura familiar para garantir a sustentabilidade ecológica está relacionado com sua capacidade de conviver em equilíbrio dinâmico com o ecossistema natural, pois o percebe como parte constituinte do patrimônio familiar que Ihe foi legado por herança, mas, a literatura revela: "Quando em situação de risco, o que pode ser representado pela escassez de terra frequente com a 
reprodução das famílias, a agricultura familiar pode vir a atuar de forma nociva ao meio ambiente" (ALTAFIN, 2007:16).

Noronha (2003), em seu trabalho realizado em comunidade tradicional, no Vale do Jequitinhonha-MG, cita que existe, no senso comum, uma visão elitizada sobre a preservação do meio ambiente e, por conta disso, algumas políticas de preservação para o meio ambiente podem desconsiderar o conhecimento e a prática conservacionistas das populações rurais tradicionais.

Lá... Onde o sol ainda bem não anunciou se irá brilhar ou não, o galo está cantando e a vaca mugindo, o agricultor e sua família já se preparam para sua rotina. A alimentação do gado ou a ordenha da vaca; seguem os ritmos que não podem ser integralmente submetidos ao industrial, pois estão condicionados aos processos da natureza ao qual a labuta do campo é que vem se ajustar.

Tais ritmos, não são devidamente compreendidos por sujeitos outros que não vivenciam esta realidade, mas a jornada burocrática da pesquisa para quem uma certa concepção de realização no trabalho, não atravessa as dimensões extraeconômicas de grande significação no meio rural.

"O objetivo de fixar o homem do campo, não com aquela visão até poética que o cara é feliz se mantendo na pobreza, ele dá condição do produtor passar por uma visão mais empresarial, visão de negócio mesmo da propriedade dele".

(técnico E).

"Uma das coisas que me entusiasmou nesse projeto foi isso. Usar com os pequenos produtores e técnicos da extensão ferramentas que grandes produtores e indústrias usam pra fazer seus controle, pra saber se estão ganhando dinheiro ou não, ferramentas administrativas: contabilidade dos custos, planilhas de manejo...". (técnico I).

A valorização que o agente da inovação tecnológica e da organização burocrática, que tenta acomodar na lógica de produção da unidade familiar, não se assemelha com a organização e estratégias utilizadas por esta. 
"O [filho] era o tirador de leite e o tratador das vacas, hoje tem um funcionário, parece que vai bem; eu e o [filho] fazemos mais serviço de fora. Eu faço de tudo, faço porteira, capino café, faço de tudo um pouquinho...".

(agricultor familiar E)

"Eu tiro esse leite e ainda vou pro café né? Faço muito serviçinho de café, faço serviço de quintal, que é uma coisa e outra, arruma uma cerca... Você tem que ser cativo, é sábado, domingo, feriado, dia santo você tem que tá ali."

(agricultor familiar B)

No âmbito da unidade familiar, outro aspecto relevante no que tange à organização das atividades, refere-se às tomadas de decisões da família. Os papéis e funções dos membros da família, aparentemente, são bem definidos; contudo, não obedecem padrões de racionalidade burocrática. As decisões centradas na figura do pai, revelam uma estrutura do tipo patriarcal, na qual, embora os relatos sugerem o envolvimento de todo o grupo familiar de forma negociada e cooperada (todo mundo ajuda todo mundo); ainda é o chefe da família que define os rumos que as coisas devem tomar.

"Esposa entra na parte da manutenção da lavagem do tanque da ordenha. Uma vez na semana ela desmonta toda a ordenha, faz a lavagem ficar mais asseada. Meu menino ajuda no leite da tarde, porque aí eu to tomando outras decisões..." (agricultor familiar D)

"Responsabilidade do sítio, no caso, é minha. Tem o meu pai que tá atrás de nós, no caso, atrás de mim, no caso; mas a responsabilidade é minha, ele é aquela pessoa que eu chego pra ele falo na hora de alguma indecisão, de alguma decisão que eu tenho que tomar eu falo: pai o que o senhor acha que eu devo fazer o que eu não devo..." (agricultor familiar B)

É na singularidade que a unidade familiar faz a gestão de seus recursos, na qual espera garantir o sustento da família e a manutenção do seu patrimônio. 
Assim, embora o produtor trabalhe também na perspectiva da geração de excedente, sua ambição em termos de acumulação vai até onde ele consiga manter a família num patamar de bem-estar, que encontra sua suficiência muito aquém do que o consumo desmedido que passaria a ter se mergulhasse inteiramente na lógica de mercado. Daí, porque o caminho pelo qual ele percorre na manutenção da propriedade e num dado ritmo e estratégias de produção, não condiz com uma adaptação irrestrita aos instrumentos e ferramentas utilizados pelas organizações e empresas modernas.

Os técnicos admitem a necessidade de interagir com os produtores levando em consideração os ritmos e autonomia decisória destes.

"Essa é a diferença desse projeto nós não tomamos decisão de nada, a decisão tem que ser dele, quando ele vai mudar o pasto, quando ele vai mudar o gado, quando ele vai comprar ordenhadeira, quando ele vai mudar para inseminação artificial, a decisão é sempre dele pra ele não jogar na sua cara que eu não queria mudar o gado e você me obrigou...".

(técnico D)

Contudo, como disse o produtor, "a prática é diferente da gramática" e a comunicação, visando a deliberação, mantém um fluxo unidirecional.

"Eles (técnicos) ajudam, eles pedem opinião e depois dão as deles, talvez a minha está lá embaixo, as deles é melhor e a gente acata, a maioria das vezes a minha está lá embaixo".

(agricultor familiar E)

"A gente que é da roça, a gente tem a idéia da gente, então eles falavam uma coisa, mas eu quero fazer assim, não mas é assim... Mas chegava sempre no consenso e fazia que era baseado em $98 \%$ naquilo que eles estavam falando, às vezes esses $2 \%$ era só pra não contrariar o produtor (risos)".

(agricultor familiar B) 
Ainda que se encontrem numa "rodada de negociação", a relação de poder é desigual e esta, não necessariamente, aparece de forma ostensiva e objetiva, ou até mesmo intencional, mas velada.

Ao sentar-se para negociar, a relação de forças mostra que, de um lado, os técnicos são portadores de um conhecimento válido para a sociedade macroenvolvente enquanto, do outro, o agricultor familiar, é portador de um senso comum que não é configurado como bom senso. Daí, o estigma de ignorante, coitado, pobre e atrasado.

Este imaginário que se tem a respeito do pequeno produtor é tão arraigado que ele mesmo, algumas vezes, se reconhece assim, numa imagem deletéria de si mesmo.

\footnotetext{
"Eu tive essa dificuldade!! Foi uma ignorância minha, reconheço que é uma ignorância...".

(agricultor familiar B)
}

“(...) você tem uma cobrança, tem uma visita deles, porque a gente é acomodado (...)"

(agricultor familiar A)

“(..) eles explica, dá assistência, o que a gente tem que fazer, porque tem muitas coisinhas que a gente não sabe né? Então pelos estudos deles, eles ensinam a gente".

(agricultor familiar $\mathrm{C}$ )

Neste caso, a interação entre os técnicos - representando a modernidade - e o agricultor familiar - como representante da tradição, pode se caracterizar uma situação de "fachada" (GOFFMAN, 1985), a partir do momento em que ambos, diante um do outro, tendam a desempenhar ou incorporar os valores oficialmente reconhecidos pela sociedade e assimilados por si mesmo para reproduzir uma relação hierárquica.

A situação de "fachada" pode ser vista, a priori, como algo desaconselhável, mas o que é importante reconhecer é que, nos processos interativos, os sujeitos estão sempre a desempenhar papéis que lhes são socialmente atribuídos. Reconhecer isto, pode ajudá-los a melhorar a construção social de suas identidades e qualidade do diálogo entre si. 


\subsubsection{Produção familiar e sua interação com o mercado: a inovação como ponte desejada/eficaz?}

Nos tempos atuais, mudanças profundas vêm ocorrendo nas formas de intermediação entre a produção familiar e o mercado, que são influenciadas por fatores externos e internos. Para os primeiros, verificam-se as novas relações econômicas e políticas e, no segundo caso, é possível que o meio rural passe por um processo de diversificação social, cuja interação com o espaço urbano não será mais antagônica devido às relações de complementaridade (WANDERLEY, 2007). Isto está relacionado com a pluriatividade exercida pela agricultura familiar, como estratégia de reprodução material.

Houve um tempo, entretanto, que as propriedades rurais tinham uma certa autonomia de inserção no mercado; produziam quase tudo e, praticamente, só compravam fora o sal e o querosene. Somente a partir da consolidação do mercado interno, de meados ao final dos anos de 1980 é que há o acesso, no meio rural, a outros itens de consumo menos conhecidos ou completamente novos. Este fato, veio contribuir para estreitar suas relações com as cidades (Cândido, 1964) e, mais recentemente, com a sociedade globalizada encetando uma articulação de técnicas que, no interior da produção, a conecta com a modernidade.

\footnotetext{
"Esse ordenamento que o programa dá, ou seja trabalho com alimentação, depois com genética, depois com qualidade do leite isso favorece o encadeamento, uma coisa já se prepara pra outra tecnologia, então ele rompe bem com o modo tradicional". (técnico A)
}

Apesar do esforço de modernização da pecuária bovina de leite, as negociações do agricultor familiar com o mercado, sempre ocorreram em condições discrepantes entre as formas e condições da aquisição dos insumos e as condições de venda de seu produto na cadeia produtiva.

No caso do leite, os preços de venda são oscilantes e estão sujeitos às alterações do mercado, no qual os produtores não estão devidamente fortalecidos devido à alta perecibilidade de sua mercadoria. 
Segundo um dos entrevistado, uma situação de instabilidade vivida pelos produtores de leite, especialmente os da agricultura familiar, é o fato deles não terem, ao certo, informações sobre o preço real do seu produto, ou seja, há a entrega do produto à cooperativa, mas nunca se sabe quanto irá receber por ele, o que é uma situação comum tanto àqueles que estão no projeto "Balde Cheio", quanto os que não estão.

\footnotetext{
"Você tem que acreditar, você tá aí no meio, que a rentabilidade é muito curta, apesar de agora o leite ter melhorado de preço, toda vida foi bem diminuindo o rendimento... O retorno [risos] parece que é muito pouco...".

(agricultor familiar A)
}

"Porque leite nós nunca tivemos estabilidade, nós tivemos há dois anos atrás nós vendemos leite a $R \$ 0,57$ centavos, deu aquela queda nós veio vender leite a $R \$ 0,29 \ldots$ Agora, segundo a [cooperativa], disse que esse mês que fechou, que é o mês de agosto, diz que tem mais quatro, cinco, seis centavos. A gente não sabe o que é que vem, é ilusório, você manda todo seu produto pra depois saber quanto que vai receber".

(agricultor familiar B - sem interação)

Como se não bastasse a instabilidade quanto à forma de remuneração do seu produto, o agricultor familiar ainda precisa transitar entre um modelo ou outro e preocupar-se, adicionalmente, com as condições sanitárias que garantam a segurança do alimento e amplie o potencial dos elos finais da cadeia produtiva, para atender as demandas dos mercados externos.

A legislação federal criou a classificação A, B e C para produção de leite cru (Decreto 30.691, 29/03/1952), cujo foco era a qualidade da mercadoria; esta preconizava métodos de higiene na ordenha, modo de transporte e de armazenamento. Alguns produtores, então, investiram em infra-estrutura física como tanque de expansão, ordenhadeira mecânica e construção de instalações apropriadas, a fim de adequarem-se a esta realidade. A expectativa de retorno deste investimento seria a forma de uma "melhor" remuneração do leite. 
Porém, ao acreditar, nesta possibilidade, pois, como disse o produtor, "a gente é teimoso", o agricultor familiar buscou adaptar-se ao mercado moderno, mas o mesmo alterou-se antes mesmo que os investimentos dessem o retorno.

\footnotetext{
"Teve uma época que a gente investimos, fizemos estábulo de leite "B". Você já ouviu falar sala de leite B? Nós fizemos estábulo pra ser coisa mais simples, porque no leite B podia fazer estábulo simples, porque o leite $B$, na época, ele tinha outro valor, então a gente investiu por 9/10 anos, a partir daí a [cooperativa] deixou de exigir 0 leite "B" e passou a ser leite por qualidade, então esse investimento todo a gente perdeu ele (...)".

(agricultor familiar B - sem interação)
}

Hoje, os parâmetros exigidos para produzir este mesmo leite sob o mesmo atributo de valor "qualidade", os requisitos são outros. Porém, o argumento para seduzir o produtor continua o mesmo, qual seja: a expectativa de uma melhor remuneração.

"De uma certa forma, existe classificação. É o leite tipo A, B, e C...
Mas, eu acredito que a tendência também disso é acabar. Hoje,
nessa normativa 51 , a tendência é a gente se enquadrar naqueles
parâmetros... Isso aí são fatores que vão contribuir para que você
tenha uma remuneração mais justa no mercado".
(técnico C)

É esta característica de descontinuidade da modernidade, à qual agora é uma coisa, mas dentro de pouco tempo vira outra, que pode gerar desconfiança e insegurança sobre os sistemas peritos e levar o agricultor familiar a manter-se com um pé na modernidade (pois é sua "garantia" de permanência no mercado) e outro na tradição (segurança ontológica).

Uma das alternativas propostas por instituições modernas voltadas para projetos com a agricultura familiar - a exemplo da CATI ou a própria Embrapa Pecuária Sudeste - está relacionada à valorização de formas organizativas via associações ou grupos de produtores. Esta alternativa daria aos produtores um poder maior de barganha em suas negociações com o mercado, ao mesmo tempo 
em que esse coletivo engendraria que todos os seus membros padronizassem suas técnicas gerando, assim, uma auto-fiscalização.

"Seria uma boa idéia de ter uma Associação deles que tivesse derivados de leite, queijo... Produzidos pelos pequenos produtores em determinada região tem um apelo comercial interessante". (técnico E)

"O acesso não é muito fácil, principalmente se o sujeito é pequenininho, mas é outra conseqüência dessas associações... A gente estimula, mas não obrigamos ninguém... Ele só vai pagar pelo individualismo dele".

(técnico D)

Mas, os grupos investigados - com interação e sem interação -têm resistência a esse tipo de organização.

"No ano passado a gente comprou farelo de soja, num grupo... Aí os que entraram comigo, pra comprar comigo o farelo de soja, reclamaram, então não tem jeito de trabalhar em grupo...". (agricultor familiar E)

"Aqui no caso, eu não faço, associação não.. Agora em questão de associação, a minha associação é com esse companheiro meu, o [vizinho], a gente tem esse... ou vai comprar isso, vou, vamos comprar junto... Pra poder dá mais um pouquinho de volume a gente trabalha junto nesse sentido. Quando há necessidade!" (agricultor familiar B)

"Até pra organizar esse tipo de associação é complicadíssimo!! Precisa ter na região uma filosofia de que eu sou seu companheiro e você é meu companheiro, nós trocamos pra conseguir ir melhor". (agricultor familiar F - sem interação).

Ademais, ao lado de outra forma de organização, para a inserção do produtor no mercado moderno, espera-se que ele adquira conhecimentos e competências 
cada vez mais complexos como novos conhecimentos culturais, genético, administrativos e, inclusive, de informática (WANDERLEY, 2007).

Para a síntese desse capítulo, lançaremos mão dos indicadores constantes do projeto "Balde cheio"; no que diz respeito ao conjunto da técnica, o qual pretende intervir junto ao produtor, os quais foram descritos no início deste capítulo de forma mais detalhada, mas agora recuperamos sucintamente e de maneira imbricada: agropecuárias, ambientais e gerenciais. A fim de fazer uma análise mais consistente sobre os resultados dessa interação, ou seja, o que a instituição alcançou ou não.

O padrão produtivo apresentado pelos agricultores familiares demonstra características que se aproximam de um modelo baseado em práticas tradicionais, mas que se revela ou intenciona à incorporação de novas formas de produzir modernas. No entanto, não significa a aceitação pacífica, ela é imbuída de resistências e produzida sob ambigüidades que revelam a sua não sujeição completa e autodeterminação. Tal constatação também é confirmada pelo grupo de controle, no qual o agricultor mantém práticas da tradição, como a ordenha manual, mas adere a outras de padrões modernos, como o tanque de expansão (Foto 13).
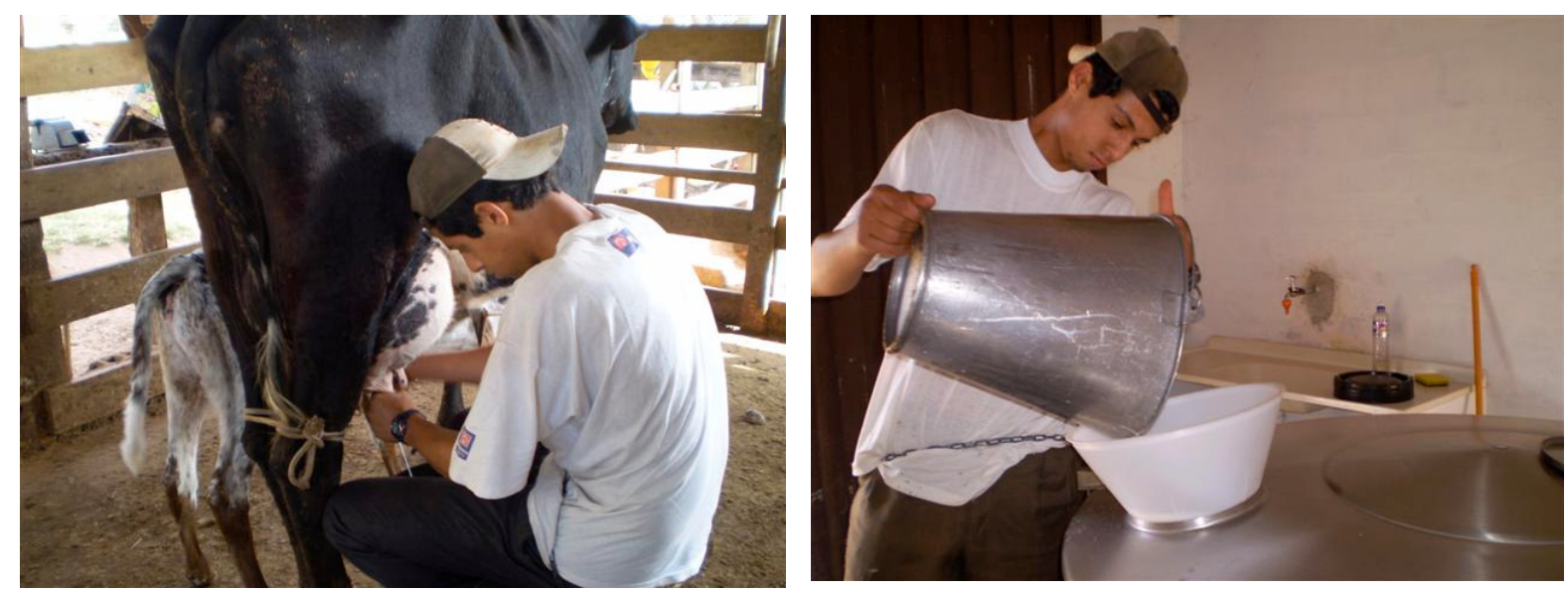

FOTO 13: produtor realizando a ordenha manual, uma prática da tradição, para em seguida, acondicionar o leite no tanque de expansão, uma prática moderna.

A adesão das tecnologias propostas pela instituição pública se acomoda bem em alguns pontos, como, por exemplo, o pastejo rotacionado, mas mostrou-se ineficaz para o controle dos dados de gestão da atividade leiteira, que atende a uma racionalidade empresarial, diferentemente da apresentada pelo produtor. Nos aspectos ambientais, a intervenção da Embrapa pouco fez diferença, pois no 
entendimento do produtor, ele já exerce tal responsabilidade, a exceção do pasto, cuja tecnologia passou a favorecer sua propriedade.

Nestes três itens acima mencionados, para o primeiro, o grupo de controle demonstrou que a adesão ao pastejo rotacionado, alcançou relativo sucesso junto ao produtor com quem interagiu, pois para o primeiro, a prática de soltar o gado a pasto persiste:

"Aqui, tirar o leite é normal, tudo é manual, agora o pasto, não tem igual, a reforma do pasto eu não faço, não tem recurso pra isso, a renda é muito pouca... As vacas, solto pro pasto".

(agricultor familiar G - sem interação)

"Faz todo dia, nós não tem pasto mesmo, ainda mais nessa época, eu tratado o gado no cocho".

(agricultor familiar C - sem interação)

"Porque nas águas praticamente a vaca enche a barriga no pasto, ela vem no curral só pra tirar o leite, tirou leite, outra vez, você não vê vaca mais..."

(agricultor familiar B - sem interação)

no caso do segundo, controle dos dados, o grupo de controle corrobora uma prática de gestão que não se aproxima da visão empresarial. Neste sentido, assemelha-se ao grupo com interação:

"Papai fazia muitas coisas, ele não era bobo não... Esse negócio de inseminar vaca mesmo, por vaca com boi, agora eu e o [irmão] acaba bagunça um pouco... Acaba bagunçando, não é certinho... Aí tem que melhorar muitas coisas, às vezes é falta de tempo".

(agricultor familiar D - sem interação)

"A gente controla isso mensal, é um negócio pequeno então dá pra saber, tem anotado tudo que está se passando...".

(agricultor familiar B - sem interação) 
"As contas eu mesmo anoto. Eu anoto tudo, os gastos que eu faço, se não fizer conta... O gado eu faço relatório, faço as vacas que nasce, as vacas que dá, sempre pra ter o controle".

(agricultor familiar E - sem interação)

Quanto ao meio ambiente, salvo a recuperação do pasto, o grupo de controle mantém práticas muito próximas do grupo com interação:

\footnotetext{
"Tem mina! É muito boa, tem córrego, tem muita água, nós protege a mina, tem cama de frango pra esterco, esterco verde pra tratar de minhoca, ajuda né?"

(agricultor familiar C - sem interação)

As nascentes nossas são muito próxima de brejo, então elas estão tudo mais ou menos assim como diz, com a vegetação bem adiantada, tem muita vegetação a gente vem deixando já há muito tempo, beirada de córrego, quando a gente vai roçar, você pode ver que já está bem arborizada".

(agricultor familiar B - sem interação)
}

As práticas aqui observadas, da pecuária leiteira em estabelecimentos familiares, apresentam semelhanças e diferenças entre os produtores participantes do projeto e o de controle. Assim como o primeiro, o segundo também combina formas tradicionais e modernas na condução das suas atividades. No que tange as representações acerca das suas relações interpessoais, ambos mantêm estreito vínculo com valores e crenças tradicionalmente herdados, bem como se assemelham quanto às características produtivas: propriedade, trabalho e família caminham juntos, ratificando o referencial teórico consultado.

Na seqüência, faremos algumas considerações finais acerca deste trabalho. 


\section{CONSIDERAÇÕES FINAIS}

Neste trabalho buscamos analisar a qualidade da interação entre estes agricultores familiares e a Embrapa Pecuária Sudeste, no âmbito do projeto "Balde Cheio", no qual se ensejou descrever as relações entre o moderno e o tradicional, e até que ponto o primeiro é capaz de influenciar o segundo por meio de suas práticas.

No capítulo 1 levantamos a problemática de um modelo econômico baseado na modernização da agricultura, o qual, no Brasil, a preocupação do estado foi em criar instituições que modificassem o campo colocando-o plenamente na lógica capitalista, para tanto, valorizou a grande produção e esqueceu a pequena produção. Entretanto, mais tarde, a partir da mobilização de movimentos sociais, o Estado reconhece que a pequena produção também era importante e cria política pública específica, como o PRONAF. Esta reorientação produziu algum horizonte de êxito relativo para a agricultura familiar. Contudo, no tempo em que vivemos um ambiente de modernidade, esta não consegue conviver lado a lado com a tradição, sem desqualificá-la. No Brasil, isto também vem a partir do Estado, que com suas instituições burocráticas, quiseram reconformar não apenas o espaço da cidade, mas o do campo também. Tem-se, então, que a intervenção do Estado, viabilizando a modernização, orientou-se no sentido que favorecesse o capital, em detrimento de políticas efetivas que tivessem sustentabilidade econômica, social, cultural e ambiental.

No capítulo 2 mostramos aspectos da criação da instituição pública Embrapa, como política e instrumento do Estado para o projeto de modernização da agricultura. Concluímos que é por meio do Estado, ou seja, da Embrapa, que se materializa parte da intervenção estatal na forma de seus pacotes tecnológicos e estabelecimento de padrões do uso de determinadas inovações técnicas, configurando-se como uma instituição moderna.

No capítulo 3 buscamos caracterizar a agricultura familiar em seus aspectos qualitativos, ou seja, focado em seus saberes e suas práticas, que contemplem questões da sua subjetividade e que the confere diferenciações (modo de fazer, modo de vida, pensar, valores etc.). A agricultura familiar constitui-se um modo de vida, no qual, sustenta suas relações interpessoais e de trabalho. Muitas das suas práticas são baseadas naquelas advindas de sua herança familiar, cujo valor afetivo 
é relevante. No mundo da modernidade, é capaz de desenvolver formas adaptativas de resistência e autodeterminação no sentido de garantir a sobrevivência da família e da propriedade. Dada a sua heterogeneidade, não é possível atribuir um conceito que a caracterize como uma "categoria" social, porém três aspectos são básicos: trabalho, família e propriedade.

No capítulo final, debruçamo-nos no estudo de caso, o qual partiu de duas perspectivas:

1- as representações sociais que os sujeitos envolvidos têm um do outro e;

2- as práticas da agricultura familiar relacionadas à produção, propriedade e mercado.

Tais perspectivas tiveram como base, o conjunto de técnicas abordado pelo projeto "Balde Cheio" que suscita mudanças nos aspectos agropecuários, ambientais e gerenciais com seus respectivos atributos; conforme descrito no capítulo quatro e nos quais a Embrapa Pecuária Sudeste aspira obter sucesso. Aqui eles serão analisados imbricadamente.

Sobre o primeiro item, o estudo revelou que a qualidade dessa interação é preocupante no que concerne aos juízos prévios que o meio perito tem dos produtores, vistos como coitados que precisam ser salvos deles mesmos; isso é impeditivo do estabelecimento de empatia, reciprocidade, entendimento e melhor conciliação entre os conhecimentos das partes.

O ritmo próprio da unidade familiar não é o da racionalidade moderna (embora contenha aspectos dela), mas de um modo de ser e fazer imbuídos de sentimentos que valorizam a herança e o pertencimento.

O grupo de controle permitiu verificar, para a tecnologia em questão, que existem outras formas de acessá-la que não passa, necessariamente, pela interação com a Embrapa e seu projeto. Mas, também, que tem suas razões para resistir ao contato direto.

Também o grupo com interação, apesar de respeitar e reconhecer o papel social da Embrapa na modernização do campo, não deposita nela a confiança total que a instituição esperaria. Os produtores mantêm-se cautelosos e reticentes, pois preferem, muitas vezes, preservar saberes e conhecimentos acumulados na sua herança familiar.

Quando o Estado, na figura das suas instituições modernizadoras, acredita e reforça a idéia que resolverá os problemas da sociedade, sem, contudo, reconhecer 
as diferenças que facilitarão seus pontos de acesso, dificilmente obterá sucesso nas suas formas de intervenção e de interação. Ao contrário, promoverá o distanciamento na interlocução que visa promover.

Observou-se que, para a instituição modernizadora, o "outro" é sempre alguém que está lá, num lugar tal que ela possa chegar e levar "soluções", numa relação de subalternidade que não se revela objetivamente; embora no discurso, são ditas relações nas quais o ponto de vista do outro é respeitado e valorizado aguarda-se, de fato, pelo seu adestramento voluntário. Aos peritos, é importante crer que o outro necessita de sua intervenção irrestrita, pois desta crença resulta o sentido da manutenção da instituição, como estrutura e dinâmica. Porém, para a agricultura familiar, o conhecimento perito se coloca não como possibilidade única da relação e prática, mas como uma alternativa frente a outras.

$\mathrm{Na}$ análise conjunta do segundo item - produção, propriedade e mercado embora a influência de práticas modernas sobre as tradicionais como, por exemplo, no melhoramento do pasto, não houve ruptura dos produtores com a forma tradicional de organizar sua rotina de trabalho reveladas quando, por exemplo, na ordenha, o bezerro é amarrado ao pé da mãe como estratégia, na qual se crê que a vaca sente-se bem para oferecer mais leite; além de questões raciais que influenciam esse aspecto da vaca e bezerro.

Tais práticas não significam, uma ignorância ou uma insegurança em relação ao objeto de trabalho - a vaca e seu meio ambiente, mas o entendimento de um trabalho que se realiza e se reelabora considerando a dinâmica ecossistêmica.

No que se refere à gestão da unidade, observou-se uma racionalidade própria do agricultor familiar, ratificada pelo grupo de controle, e que é, essencialmente, diferente da requerida pelos técnicos.

Enquanto para estes, suas ações sugerem cálculos quantitativos, com o objetivo de maximizar os lucros e diminuir os custos para o agricultor familiar; para aquele, sua lógica está baseada na melhoria das condições de produção da sua propriedade relacionada à melhoria do bem estar da sua família a um patamar de aspirações materiais que, aos técnicos, podem parecer modestos, mas que entremeiam a manutenção de diversas habilidades no exercício da jornada de trabalho; a autodeterminação, as dimensões econômicas e extra-econômicas no sentido do produzir. Isso significa que o interesse do produtor em permanecer como 
tal não é render-se à busca da imagem de empresário e de uma racionalidade condizente com a mesma.

Durante este estudo, verificou-se que este é um ponto de maior exigência, por parte do técnico, quando da sua interação com o produtor, levando a cessar a interação caso o segundo não aceite a plena acomodação aos ideários do primeiro.

O técnico ao impor esta condição ao produtor, desqualifica a lógica ou o modo de fazer que não converge aos seus propósitos, mas, que sob o ponto de vista do produtor, são saberes e fazeres com sua importância e confia neles.

Em relação ao mercado, a agricultura familiar vem sendo instada a ampliar a oferta de leite e os tanques de expansão são a técnica a qual muitos aderiram.

Os tanques de expansão, presentes hoje, na maioria das propriedades entrevistadas, significam garantia de venda, mas não necessariamente, melhoria de preço, pois este é definido pelos agentes do topo da cadeia produtiva. Os tanques, uma exigência legal e não apenas do projeto, otimizaram a aproximação entre as cooperativas e os produtores; porém como se trata de uma relação na qual os preços finais são variáveis, as incertezas quanto ao retorno dos investimentos, coloca novas desconfianças em relação às inovações tecnológicas que lhes são oferecidas.

Para o produtor, seu mercado é a cooperativa; então, o fascínio por grandes mercados é algo que não está presente no seu imaginário. Sobre este aspecto, o projeto da Embrapa, que focalizamos nesse trabalho, não contribuiu diretamente para que as cooperativas da região discriminassem os produtores segundo as inovações incorporadas, tendo todos a sua oferta de leite acolhida indiscriminadamente.

A modernização da agricultura suscitou críticas, severas, de teóricos, ambientalistas e outros grupos sociais preocupados com os efeitos danosos que ela causou ao meio ambiente. O conjunto da técnica proposto pela Embrapa sugere um alento para tais efeitos pautado na sustentabilidade ambiental, conferida a partir da recuperação do pasto degradado por práticas tradicionais, recomposição da mata ciliar, manutenção ou ampliação da área de preservação permanente, enfim, contribui para o cumprimento da legislação ambiental.

Este é um ponto considerado positivo para o conjunto da técnica. Todavia, existem controvérsias entre esse mesmo corpo perito, o qual levanta alguns pontos negativos e potencialmente de risco que estão relacionados à insustentabilidade da 
atividade em função da dependência externa de insumos, da concentração de esterco em áreas menores, com perigo de contaminação de corpos d'água e o estímulo ao uso da irrigação. Estas considerações são potencializadoras de consequências tardias, para as gerações futuras das famílias, que permanecerão na propriedade. Por outro lado, o arcabouço legal ambiental muito estrito coloca o produtor em dilemas na forma adequada de utilização da área.

O estudo revelou que o grupo considerado "com interação" já adotava algumas práticas conservacionistas que, então, estavam no escopo de sua própria cultura como, por exemplo, foco na preservação das nascentes, por estas significarem condições de sobrevivência do núcleo familiar. Eles dizem: "nós sempre cuidamos". Mas, no que se refere à conservação do pasto, o capital cultural dos produtores entrevistados pareceu valer-se favoravelmente ao conjunto da técnica voltado para a sua recuperação; por exemplo, evitando a queima e perda de nutrientes do solo daí decorrente.

A interação, com os técnicos da Embrapa, pouco mudou as práticas ambientais adotadas pelos agricultores familiares, afora o pasto. Mesmo porque, no projeto focalizado, os cuidados com o meio ambiente não é considerado prioritário ou motivo de exclusão do produtor caso não adote, como ocorre com as anotações dos dados da contabilidade. Ele é considerado uma conseqüência no conjunto da adoção da técnica agropecuária assim como a melhoria de renda, melhorias que não foram observadas pelas razões expostas ao longo do estudo.

Outras técnicas aparecem indistintamente nos dois grupos de agricultores familiares - demonstrando que a interação direta não é a forma de convencimento mais eficaz - assim como resistências que aparecem como conflito e desejo de isolamento.

Se pensarmos na organização das tarefas e papéis na unidade familiar, ela se caracteriza por uma estrutura do tipo patriarcal, cujo poder decisório é centrado na figura do pai. Em alguns poucos casos a mulher e filhos são chamados a opinar, porém a decisão final ainda é paterna. Desta forma, seu entendimento do mundo e do processo de decisão, não se concilia, de partida, com uma dominação racional ou técnica científica, que o faça aceitar uma autoridade exógena à família. Tais racionalidades vão se antagonizar a princípio e a submissão peculativa do primeiro ao segundo, ocorre conforme incorpora a imagem de ignorante, portador de uma cultura destituída de valor e sentido. Mas, tal incorporação é sempre parcial e as 
mudanças materiais vêm acompanhadas da sua nulificação. Isso decorre, em muito, também, quando o próprio Estado e os meios de comunicação contribuem para apresentarem o rural como espaço "menor" da sociedade.

Daí, porque o produtor pode inicialmente aceitar sua subjulgação, mas sempre como algo provisório, algo que pode vir a abandonar.

Nesta oportunidade, parece salutar retornar a atenção para o caráter da gestão patriarcal que ainda persiste subjacente em algumas situações como, por exemplo, em relação às vozes das mulheres, quando lhes são concedido breves momentos de "permissão" ou onde lhe é autorizado o uso da palavra apenas para explicar os seus afazeres domésticos e "ajudas" nas atividades da propriedade; mas quase nunca sobre sua contribuição efetiva na economia familiar. $\mathrm{Na}$ atividade econômica, lhe é atribuído apenas o papel de "ajudante", não aquele remunerado, mas o que aparece na forma de contribuição.

Muitas dessas mulheres assumem o papel de gestora, não apenas na ausência do marido, mas também quando este titubeia na tomada de decisão ou mesmo, quando, na intimidade familiar, de fato, é ela quem decide os rumos a seguir, mas que não deve ser revelado publicamente.

Desta forma, num outro momento, fica a sugestão para uma análise de gênero na interpretação do modo de vida dessa população rural, no sentido de pensar programas que valorizem o trabalho da mulher com vistas a gerar certa eqüidade nesta relação.

Ao concluir, registramos que apesar do reconhecimento dos grupos em interação dos benefícios inerentes ao conjunto das inovações, que lhes foram ofertadas, na análise das representações dos sujeitos acerca de suas relações, pôde-se perceber as tensões subjacentes que denotam a ausência de uma efetiva dialogicidade entre os sujeitos envolvidos.

É possível afirmar, que há paulatina influência das práticas modernas sobre as tradicionais; contudo, esta não se rende completamente. Ela sobrevive em função de sua lógica de reprodução social, bem como de uma herança cultural, nos quais o produtor deposita plena confiança, por serem eles, também, um fator identitário.

Ao Estado cabe, por meio de suas instituições, ampliar seu horizonte de compreensão em relação à agricultura familiar, entendendo-a como um modo de vida, constituído de fazeres que tem valor histórico, de memória e de identidade e 
que, portanto, não deve ser confundido com uma empresa e sua racionalidade burocrática, no que concerne aos projetos voltados para este segmento produtivo.

$E$, por fim, espera-se que as análises das divergências explicitadas quando à visão do problema e das soluções havidas entre a instituição pública Embrapa Pecuária Sudeste e os agricultores familiares, possam ser úteis ao aprimoramento da qualidade da interação num futuro próximo. 


\section{REFERÊNCIAS BIBLIOGRÁFICAS}

ABAG - Associação Brasileira de Agribusiness (1993). Segurança alimentar: uma abordagem de agribusiness. São Paulo: edições Abag.

ABRAMOVAY, R. (1997). Agricultura familiar e uso do solo. São Paulo em Perspectiva - Abr/jun, vol. 11, no 2: 73-78. Disponível em:

$<$ http://www.econ.fea.usp.br/abramovay/artigos_cientificos/1997/Agricultura_familiar. pdf>, acesso em 24/09/2007.

(2001). Conselhos além dos limites. In: Estudos Avançados, Scielo, vol. 15, № 43, São Paulo, setembro/dezembro.

AGUIAR, R. C. (1986). Abrindo o pacote tecnológico: Estado e pesquisa agropecuária no Brasil. São Paulo: Polis; Brasília, CNPq.

ALBERGONI, L. (2007). Da revolução verde à transgenia: ruptura e continuidade de paradigmas tecnológicos. Disponível em: <http://www.peteconomia.ufpr.br/textos/relatorio_evinci_leide.htm>, acesso em 16/04/2007

ALENCAR, M. M. de et al (1988). UEPAE de São Carlos: 13 anos de pesquisa. São Carlos, EMBRAPA/UEPAE de São Carlos, Documentos 10.

ALTAFIN, I. (2007). Reflexões sobre o conceito de agricultura familiar. Professora da Faculdade de Agronomia e Medicina Veterinária da Universidade de Brasília, FAV/UnB. Doutora em Desenvolvimento Sustentável - CDS/UnB. Disponível em: $<$ http://www.agroecologia.cnptia.embrapa.br/biblioteca/agriculturafamiliar/CONCEITO\%20DE\%20AGRICULTURA\%20FAM.pdf>, acesso em 29/09/2007.

ALVES, E. R. A. (1979). O sistema cooperativo de pesquisa do Ministério da Agricultura. In: IV Reunião Anual de Dirigentes da Embrapa. EMBRAPA, Brasília.

ARRUDA, A. (2002). Teorias das representações sociais e teorias de gênero. Cadernos de Pesquisa, n117, p. 127-147. Disponível em:

$<$ http://www.acaoeducativa.org.br/downloads/teoria_das_representacoes.pdf>. Acesso em 03/05/2006.

BADALOTTI, R. M. e REIS, M. J. (2005). Representações dos agricultores familiares sobre programas de cooperação agrícola e agroecologia. In.: Juliana Silvia Guivant, Luiz Fernando Scheibe e Selvino José Assmann (org.), Desenvolvimento e conflitos no ambiente rural., Florianópolis: Insular, 296 p.

BECKER, H. S. (1997) Métodos de pesquisa em Ciências Sociais. São Paulo: Hucitec.

BERMAN, M. (1996). Tudo o que é sólido desmancha no ar. Companhia das Letras, São Paulo. 
BIANCHINI, V. (2007). O universo da agricultura familiar e sua contribuição ao desenvolvimento rural. Disponível em:

familiar<http://www.agroecologia.cnptia.embrapa.br/biblioteca/agriculturafamiliar/AgriFam\%20texto\%20CNA\%20Bianchini.pdf>, acesso em 30/09/2007.

BNDES (2007). A empresa. Disponível em:

<http://www.bndes.gov.br/empresa/default.asp>, acesso em 13/06/2007.

BONNAL, P. et al (1994). Modernização da agricultura camponesa e estratégia dos produtores: projeto Silvânia, Estado de Goiás, Brasil. Planaltina: EMBRAPA-CPAC, 24 p. (EMBRAPA-CPAC. Documentos, 55).

BONNY, S. (1993). A padronização tecnológica na agricultura: formas, origem e perspectivas a partir do caso francês. Cadernos de Ciência e Tecnologia, Brasília, v. 10, n. 1/3, p. 9-34.

BOURDIEU, P. (2001). O poder simbólico. Tradução Fernando Tomaz (português de Portugal), 4 ed, Rio de Janeiro: Bertrand Brasil.

BRASIL (1970). Ministério do Planejamento e Coordenação Geral. Metas e Bases para a Ação de Governo. Brasília, MINIPLAN, 126p.

BRASIL (1971). Ministério do Planejamento e Coordenação Geral. I Plano Nacional de Desenvolvimento - 1972/74. Brasília, MINIPLAN, 77p.

BRASIL (1973). Ministério do Planejamento e Coordenação Geral. I Plano Nacional de Desenvolvimento - 1973/74. Brasília, MINIPLAN, 155p.

BRASIL (2006). Lei 11.326, de 24 de Julho de 2006. Estabelece as diretrizes para a formulação da Política Nacional da Agricultura Familiar e Empreendimentos Familiares Rurais. Diário Oficial da União, dia 25/07/2006.

BRASIL (2008). Lei no 11.105, de 24.03.2005. Portal do Ministério da Ciência e Tecnologia. Disponível em:

<http://www.mct.gov.br/index.php/content/view/1034.html>, acesso em 05/01/2008.

CABRAL, J. I. (2005). Sol da manhã: memória da Embrapa. Brasília: UNESCO, 344.

CANDIDO, A. (1964). Os parceiros do rio bonito. Coleção Documentos Brasileiros, Rio de Janeiro: Livraria José Olympio.

CARNEIRO, M. J. (2005). Significados da pluriatividade para a família rural. Trabalho apresentado no Seminário Nacional de Desenvolvimento Rural Sustentável, Brasília, 23 a 25 de agosto de 2005.

CATI (2007). Coordenadoria de Assistência Técnica Integral: Relatório apresentado ao Instituto Econômico Agropecuário, Campinas, SP. 
CNUMAD (1992). Agenda 21. Disponível em:

<http://www.crescentefertil.org.br/agenda21/index2.htm>. Acesso em 19/04/2006.

EMBRAPA (1986). Embrapa hoje. Ministério da Agricultura - MA. Assessoria de Imprensa e Relações Públicas - AIRP, Brasília.

EMBRAPA (1993). Centro de Pesquisa de Pecuária do Sudeste. Plano Diretor do Centro de Pesquisa de Pecuária do Sudeste - CPPSE. São Carlos, SP, 37p.

EMBRAPA (2000). Embrapa Pecuária Sudeste. II Plano Diretor: Embrapa Pecuária Sudeste 2000-2003 / Embrapa Pecuária Sudeste. - São Carlos, SP: Embrapa Pecuária Sudeste, 43p, Documentos 28.

EMBRAPA (2002). Pesquisa agropecuária e qualidade de vida: a história da Embrapa / Embrapa. - Brasília, DF, 244p.

EMBRAPA (2004a). Embrapa Pecuária Sudeste. Relatório final do projeto Implantação, acompanhamento e avaliação de tecnologias com produção de leite no Estado de São Paulo, São Carlos, SP.

EMBRAPA (2004b). Supervisão de Atos de Gestão. Ano XXX - BCA № 5, de 02.02.2004 -SMS, Resolução 01.

EMBRAPA (2004c). Manual do Sistema Embrapa de Gestão: características e gestão do Macroprograma 6: apoio ao desenvolvimento da agricultura familiar e à sustentabilidade do meio rural. Resolução Normativa no 1 de 29/01/2004.

EMBRAPA (2005). Embrapa Pecuária Sudeste. III Plano Diretor: Embrapa Pecuária Sudeste 2004-2007. - São Carlos, SP: Embrapa Pecuária Sudeste, 44p, Documentos 41 .

EMBRAPA (2006a). Embrapa: nace la nueva agricultura de los trópicos. In: El negocio del agro en Brasil. Ministerio de Relaciones Exteriores, editora Pap. Expansão Ltda.

EMBRAPA (2006b). Agricultura familiar na dinâmica da pesquisa agropecuária. Editor Técnico, Ivan Sergio Freire de Sousa. - Brasília, DF: Embrapa Informação Tecnológica, 434p.

FAPESP (2007). Revista Ciência e Tecnologia no Brasil. Abril, oo 134.

FERNADES, F. (1979). Mudanças sociais no Brasil. Série Corpo e Alma do Brasil, v. 3, 3 ed., São Paulo: DIFEL.

FERREIRA, C. R. C. (2007). Como o agricultor familiar pode conseguir e manter o financiamento rural e como se dá à relação com os bancos. Ministério do Desenvolvimento Agrário - MDA, Secretaria da Agricultura Familiar. Disponível em: <http://www.mda.gov.br/saf/arquivos/1137912740.doc>, acesso em 01/10/2007. 
FLORES, M. X. (1991). A pesquisa agropecuária no Brasil. Brasília: EMBRAPA-SEA, 23p. Documentos 6.

FREIRE, P. (1983). Extensão ou comunicação? Tradução Rosisca Darcy de Oliveira, 8 ed, Rio de Janeiro: Paz e Terra, 93 p., (O Mundo, Hoje, vol. 24).

(1996). Pedagogia da autonomia: saberes necessários à prática educativa. São Paulo: Paz e Terra, 33ª̣ ed - (Coleção Leitura).

FREITAS, E. de (2007). Revolução Verde. Disponível em:

$<$ http://meuartigo.brasilescola.com/geografia/revolucao-verde.htm>, acesso em 28/12/2007.

FREYRE, G. et al (1971). Sociologia do açúcar. Recife: Instituto do Açúcar e do Álcool, $106 \mathrm{p}$.

GIDDENS, A. (1991). As conseqüências da modernidade. Tradução de Raul Fiker. São Paulo: Editora da Universidade Estadual Paulista.

BECK, U. e LASH, S. (1997). Modernidade reflexiva: trabalho e estética na ordem social moderna. São Paulo: Unesp.

(2002). Modernidade e Identidade. Rio de Janeiro: Jorge Zahar Editor.

GOFFMAN, E. (1985). A representação do eu na vida cotidiana. Tradução de Maria Célia Santos Raposo. Petrópolis, Vozes, 236p.

(1988). Estigma: notas sobre a manipulação da identidade deteriorada.

Tradução Márcia Bandeira de M. L. Nunes, 4aㅡ ed, Editora Guanabara, Rio de Janeiro, RJ.

GOODMAN, D.; SORJ, B. e WILKINSON, J. (1990). Da lavoura às biotecnologias: agricultura e indústria no sistema internacional. Tradução Carlos Eduardo Baesse de Souza e Carlos Schlottfeldr, Rio de Janeiro: Campus.

SILVA, J. G. (1982). A pequena produção e as transformações da agricultura brasileira. In: Modernização dolorosa. Rio de Janeiro : Zahar.

GUILHOTO, J. J. M., AZZONI, C. R. et al. (2007). PIB da Agricultura Familiar: Brasil Estado. Brasília: MDA; 172 p; (NEAD Estudos; 19).

HENK, H. (1990). Biotecnologia: muito além da revolução verde. As novas tecnologias genéticas para a agricultura: desafios ou desastre? Tradução: Sebastião Pinheiro, Sert Roland Fischer, Jacques Saldanha. Porto Alegre, Riocell.

IANNI, Octavio. (1998). Teorias da globalização. 5 ed. Rio de Janeiro: Civilização Brasileira. 
IPES, (2002). Instituto de Pesquisas Econômicas e Sociais: Boletim informativo de Franca, no 49, FACEF. Disponível em:

<http://200.170.150.33:8084/site2006/franca/dados.htm>, acesso em 07/03/2008.

JODELET, D. (2002). As Representações sociais: um domínio em expansão. In: JODELET, D. (org.). As Representações sociais. Rio de Janeiro: Eduerj, p.17-44.

KAGEYAMA, A. et al (1982). Tecnologia e campesinato: o caso brasileiro. Universidade Estadual de Campinas, Instituto de Filosofia e Ciências Humanas (IFCH), Departamento de Economia e Planejamento Econômico. Proyecto Cooperativo de Investigación sobre Tecnologia Agropecuaria en America Latina (PROTAAL), José Graziano da Silva (coord.), Campinas-SP.

KATTAH, E. (2007). PF desmonta quadrilha que adulterava leite. Jornal Estadão, São Paulo, 23/10/2007. Disponível em:

<http://www.estadao.com.br/estadaodehoje/20071023/not_imp69124,0.php>, acesso em 27/12/2007.

LAMARCHE, H. (coord.) (1993). A agricultura familiar: comparação internacional. Vol I: uma realidade multiforme. Tradução: Angela Maria Naoko Tijiwa,. Campinas, SP: Editora da UNICAMP.

LATOUR, BRUNO (2001). A Esperança de Pandora: ensaios sobre a realidade dos estudos científicos, Bauru, SP: EDUSC.

(2000). Ciência em ação. São Paulo: Edunesp.

MALUF, R. S. (2002). O enfoque da multifuncionalidade da agricultura: aspectos analíticos e questões de pesquisa. In: Dalmo M. de A. Lima e John Wilkinson et al (orgs.) Inovações nas tradições da agricultura familiar, Brasília: CNPq/Paralelo 15, 400p.

MARTINS, J. S. (1986). Os camponeses e a política no Brasil. Petrópolis: Vozes.

MEDEIROS, L. S. de (1997). Trabalhadores rurais, agricultura familiar e organização sindical. São Paulo em Perspectiva, 11, p. 65-72.

MOSCOVICI, S. (2005). Representações sociais: investigações em psicologia social. 2 ed. Petrópolis: Vozes.

MÜLLER, G. (1989). Complexo agroindustrial e modernização agrária. São Paulo:HUCITEC:EDUC - (Estudos rurais; 10).

NEAD Estudos (2007). Estudo sobre as convenções coletivas da categoria canavieira: São Paulo, Pernambuco e Goiás, 1989-2005 / Departamento Intersindical de Estatística e Estudos Socioeconômicos; Ministério do Desenvolvimento Agrário, Núcleo de Estudos Agrários e Desenvolvimento Rural. Brasília: MDA; São Paulo: DIEESE, 88 p; (NEAD Estudos; 17). 
NETO, C. C. (1999). Agricultura sustentável, tecnologias e sociedade. In: Mundo rural e tempo presente/Organizadores: Luiz Flávio Carvalho Costa, Regina Bruno e Roberto José Moreira, Rio de Janeiro: Mauad, 352 p.

NORONHA, A. G. B. (2003). O tempo de ser, fazer e viver: modo de vida de populações rurais tradicionais do Alto do Jequitinhonha, MG. Dissertação de Mestrado, Lavras:UFLA, 140p.

OLIVEIRA, M. M. de (2005). Como fazer pesquisa qualitativa. Recife: Editora Bagaço, 192p.

OLIVEIRA, de M. \& VASCONCELOS, Y. (2006). Revolução no canavial. In: Revista Pesquisa Fapesp, abril 2006, nº 122, p. 62-70.

OLIVEIRA, R. D. (2007). Inovação e ciências sociais: considerações sobre conhecimento e desenvolvimento. Monografia de conclusão de curso para a obtenção do título de Bacharel em Ciências Sociais. Universidade Federal de São Carlos - UFSCar, São Carlos, SP.

PARENTE, A. (2000). Pensar em rede. Do livro às redes de comunicação. In: Revista Brasileira de Ciências da Comunicação. Vol. XXIII, n1, janeiro/junho de 2000, p. 167-174.

(2007). Rede e subjetividade na filosofia francesa contemporânea. In: Revista Eletrônica de Comunicação, Informação \& Inovação em Saúde. Rio de Janeiro, v. 1, n. 1, p. 101-105, jan-jun, 2007. Disponível em:

<http://www.reciis.cict.fiocruz.br/index.php/reciis/issue/view/9/showToc>, acesso em 29/12/2007.

ROMEIRO, A. R. (1998). Meio ambiente e dinâmica de inovações na agricultura. São Paulo:Annablume: FAPESP.

RUAS, E. D. et al (2006). Metodologia participativa de extensão rural para o desenvolvimento sustentável - MEXPAR. Belo Horizonte: EMATER, março, $134 \mathrm{p}$.

RUZZA, R. C. P. de; BATISTA, L. A. R. (1986). UEPAE de São Carlos, localização, justificativa da criação, projetos de pesquisa e trabalhos publicados. EMBRAPA, Departamento de difusão de Tecnologia, Brasília, DF, 97 p.

SACHS, I. (1986). Ecodesenvolvimento: crescer sem destruir. São Paulo: Vértice.

SALMAN, A. K. D. (2007). Instrução normativa 51: um desafio para os pequenos produtores de leite em Rondônia. Artigo: Embrapa Rondônia, 28 de junho.

Disponível em: <http://www.clicnews.com.br/artigos/view.htm?id=62289>, acesso em 08/01/2008.

SANTOS, M. (2002). O país distorcido: o Brasil, a globalização e a cidadania / Milton Santos; organização, apresentação e notas de Wagner Costa Ribeiro; ensaio de Carlos Walter Porto Gonçalves, São Paulo: Publifolha. 
(1992). Espaço e método. 3 ed, SP:Nobel.

SANTOS, C. E. S. (1999). Agricultura familiar, marketing e inserção nos mercados: o sonho possível? Dissertação de Mestrado. Universidade Federal de Lavras - UFLA, Lavras, MG, $87 \mathrm{p}$.

SANTOS, B. S. (2008). Para além do pensamento abissal: das linhas globais a uma ecologia de saberes. Disponível em:

http://www.ces.fe.uc.pt/bss/documentos/Para_alem_do_pensamento_abissal_RCCS 78.PDF, acesso em 12/03/2008.

SCHNEIDER, S. (2003). Teoria social, agricultura familiar e pluriatividade. Revista Brasileira de Ciências Sociais, RBCS, vol. 18 №. 51, p. 99-121, fevereiro/2003.

SILVA, G. S. (1981). Progresso técnico e relações de trabalho na agricultura. Coleção Economia e Planejamento. Série "Teses e Pesquisas". Editora Hucitec, São Paulo.

SILVA, J. G. da. (1996). A nova dinâmica da agricultura brasileira. Campinas, SP: UNICAMP, IE.

Pesquisas, 1.

(1999a). O novo rural brasileiro. Campinas, SP: UNICAMP.IE, Coleção

SILVA, O. H. da (1999b). Agricultura familiar: diversidade e adaptabilidade. Revista de Sociologia e Política, no 12: 161-167, junho, Curitiba-PR.

SILVA, M. A. de M. (1999c). Errantes do fim do século. São Paulo: Fundação Editora da UNESP, (Prismas).

SILVA, M. A. de M. (2004a). A luta pela terra: experiência e memória. São Paulo: UNESP, 136 p. (Coleção Paradidáticos; Série Poder).

SILVA, F. C. (2004b). Sustentabilidade no espaço rural: um novo paradigma organizacional - II. Revista Agropecuária Catarinense, v. 17, no 2, julho.

SILVA, N. J. R. da (2004c). Sistema local de inovação da piscicultura: entender para desenvolver a atividade. In: Revista Panorama da Aqüicultura, Rio de Janeiro, v. 14, p. 37-41.

SILVA, A. O. (2006). Revista espaço acadêmico, no 47, abril de 2005, mensal, ISSN 1519.6186, ano IV. Disponível em:

<http://www.espacoacademico.com.br/047/47pol.htm\#_ftnref1>, acesso em 18/11/2006.

SILVA, M. A. de M. (2007a). Canavieiro. Entrevista concedida a Renato Touzpin, em 09/04/2007. Disponível em:

$<$ http://www.emdiacomacidadania.com.br/post.php?titulo=experta-em-cana-deacucar-maria-aparecida-moraes-fala-ao-site>, acesso em 06/12/2007. 
SILVA, E. L. da (2007b). Rede científica e a construção do conhecimento. Extraído da Tese de Doutorado "A construção dos fatos científicos: das práticas concretas às redes científicas. Disponível em:

<http://www.ies.ufpb.br/ojs2/index.php/ies/article/viewPDFInterstitial/156/150>, acesso em 28/12/2007.

SOUZA, N. (2007). Leite: qualidade desde o campo. Jornal O Estado de São Paulo, 14/11/2007. Disponível em:

<http://txt.estado.com.br/suplementos/agri/2007/11/14/agri-

1.93.1.20071114.38.1.xml>, acesso em 27/12/2007.

TAVARES, M. C. (1983). Da Substituição de importações ao capitalismo financeiro. Rio de Janeiro: Zahar.

TAYLOR, S. J. e BOGDAN, R. (1992). Introdución a los métodos cualitativos de investigación: la búsqueda de significados, ediciones PAIDOS, Barcelona, Buenos Aires, México.

TRIPOLDI, T. et al. (1981). Análise da Pesquisa Social. Rio de Janeiro:Francisco Alves.

VALENCIO, N. F. L. da S. et al (2005). Diagnóstico dos conflitos e das potencialidades na gestão do trabalho: o caso da Embrapa Pecuária Sudeste. Universidade Federal de São Carlos - UFSCar, São Carlos, SP.

VEIGA, J. E. da; ABRAMOVAY, R. e EHLERS, E. (2003). Em direção a uma agricultura mais sustentável. In.: Patrimônio ambiental brasileiro. Wagner Costa Ribeiro (org), São Paulo: Editora da Universidade de São Paulo: Imprensa Oficial do Estado de São Paulo - (Uspiana: Brasil 500 anos), p. 305-332.

VEIGA, J. E. da (2003a). Agricultura no mundo moderno: diagnóstico e perspectiva. In: TRIGUEIRO, A., coord. Meio Ambiente no século 21. Rio de Janeiro: Sextante.

VEIGA, J. E. da, et al (2003b). Em direção a uma agricultura mais sustentável. In: Patrimônio Ambiental Brasileiro / organização Wagner Costa Ribeiro, São Paulo: Editora da Universidade de São Paulo: Imprensa Oficial do Estado de São Paulo (Uspiana: Brasil 500 anos).

WANDERLEY, M. de N. B. (1999). Raízes Históricas do Campesinato Brasileiro. In: TEDESCO, João Carlos (org.). Agricultura Familiar Realidades e Perspectivas. $2^{\text {a. }}$ ed. Passo Fundo: EDIUPF. Cap. 1, p. 23-56.

(2000). A emergência de uma nova ruralidade nas sociedades modernas avançadas - o "rural" como espaço singular e ator coletivo. In.: Estudos Sociedade e Agricultura, 15, outubro 2000: 87-145. Disponível em:

http://bibliotecavirtual.clacso.org.ar/ar/libros/brasil/cpda/estudos/quinze/nazare15.htm acesso em 09/11/2007.

(2007). A emergência de uma nova ruralidade nas sociedades modernas avançadas - o "rural" como espaço singular e ator coletivo. Estudos Sociedade e Agricultura, 15, outubro 2000: 87-145. Disponível em: 
http://bibliotecavirtual.clacso.org.ar/ar/libros/brasil/cpda/estudos/quinze/nazare15.htm acesso em 09/11/2007.

WEBER, M. (1981). A ética protestante e o espírito do capitalismo. Tradução de M. Irene de Q. F. Szmrecsányi e Tomás J. M. K. Szmrecsányi. Coleção Weberiana, 1, Editora Universidade de Brasília, São Paulo, Pioneira. 


\section{ANEXO I}

\section{ROTEIRO DE ENTREVISTA}

\section{TÉCNICOS ENVOLVIDOS NO TRABALHO DO PROJETO DA AGRICULTURA FAMILIAR DA PECUÁRIA SUDESTE}

\section{Identificação do entrevistado:}

1.1 nome

1.2 idade

1.3 escolaridade/formação

1.4 gênero

1.5 tempo na empresa

1.6 cargo/função que exerce na empresa

1.7 área de atuação

\section{Sobre o projeto:}

2.1 quando surgiu? O que propõe?

2.2 Como? Por que/qual preocupação? Qual motivação?

2.3 Quanto tempo está vinculado ao projeto?

2.4 Qual a estrutura (seleção dos municípios, produtores, critérios etc)?

2.5 Qual sua responsabilidade/contribuição?

2.6 Quais são os parceiros/membros da equipe: qual papel?

2.7 Qual a relação do projeto com a missão da Unidade?

\section{Sobre o conjunto da técnica:}

3.1 o que propõe?

3.2 Quais as favorabilidades e os obstáculos no emprego da técnica?

3.3 A técnica em si tem algum ponto negativo? Em relação ao desenvolvimento do produtor (mudança no modo de fazer).

3.4 Qual a relação com as práticas tradicionais do produtor? Elas vêm no sentido de valorizar ou suplantar técnicas tradicionais.

3.5 Em relação ao produtor e em relação ao extensionista.Quais fatores que interferem na adoção/resistência?

3.6 Como a técnica, quando da sua adoção, contribui para a relação: tecnologia $X$ produtividade $\mathrm{X}$ rentabilidade? Visto em comparação com o estágio anterior.

3.7 Existe na técnica algo que, embora não haja ganho de produtividade ou rentabilidade, mas que produza ganhos ambientais que vale a pena incentivar 0 produtor a utilizá-la?

3.8 Como a técnica ajudou no controle sanitário/saúde humana.

\section{Sobre o mercado:}

4.1 Dentro da visão da cadeia produtiva (certificação, legislação, ganho mercado internacional, acesso fornecedor/comprador etc), em que sentido o conjunto da técnica favorece ou incentiva a atividade produtiva?

$4.2 \bigcirc$ que o conjunto da técnica contribui para a sustentabilidade (relação à certificação)/continuidade da atividade (se existem outras atividades rurais que, por mais que a técnica dê vantagens ao produtor, ele está sempre seduzido a migrar para outra atividade - biomassa, energia, outro tipo de alimento). 
5. Sobre a ocupação de mão-de-obra:

5.1 Em que medida o conjunto desta técnica contribui com a redução do esforço físico, da redução da jornada de trabalho, redução do contato com as condições do ambiente (intempéries, ambientes adversos, sujeito à contaminação saúde humana)?

5.2 Como o conjunto da técnica influencia nas formas de organização da rotina do trabalho, suas fases, no conjunto de trabalhadores envolvidos (+ gente - gente). Inclusão/exclusão/novos postos: como?

5.3 Como o conjunto da técnica amplia ou reduz a participação dos membros da família no trabalho rural. Qual importância dessa participação?

5.4 A nova forma de trabalho que o conjunto da técnica requer, incita ou eleva o estímulo do produtor em relação a suas atuais tarefas ou reduz este estímulo? Por que, como ele se sente?

6. Sobre a propriedade:

6.1 Como o conjunto da técnica contribuiu para a permanência na propriedade ou se o produtor teria que se desfazer dela e adquirir mais terra ou menos terra para permanecer na atividade.

6.2 Como o conjunto da técnica favorece a melhoria da gestão da unidade produtiva?

6.3. O modelo de gestão requerido, para o conjunto da técnica, se torna um impedimento ou é motivo de resistência para a adoção da técnica?

6.4 Como o conjunto da técnica ajuda na obtenção mais rápida dos resultados: o que interfere?

6.5 Você conhece as condições de deslocamento/mobilidade; em relação ao produto: consumidor, cooperativa, fornecedor (qual regularidade).

6.6 Você conhece as relações de vizinhança: como se dá? Se estão identificados do que produzem e da forma como fazem, eles aderiram a técnica e a relação com a CATI.

6.7 Você sabe se os produtores participam de eventos sociais/viagem que dizem respeito a congressos, exposições que ajudam na atividade produtiva.

\section{Sobre o Estado}

7.1 Qual a importância da Embrapa Pecuária Sudeste no cumprimento da sua missão institucional. Papel da Embrapa: contribuição/elaboração políticas públicas. Você acha que ela cumpre sua missão?

7.3 Qual a importância da CATI no cumprimento da sua missão institucional. Qual seu papel?

7.4 Qual a importância e o papel da Prefeitura/Secretaria Municipal da Agricultura envolvidos no projeto? 


\section{ANEXO II \\ ROTEIRO DE ENTREVISTA}

\section{AGRICULTORES FAMILIARES}

\section{Identificação do entrevistado:}

1.1 nome;

1.2 idade;

1.3 gênero

1.4 posição da estrutura da família em relação ao chefe na atividade produtiva.

1.5 escolaridade/formação;

1.6 tempo na produtividade e na atividade atual;

1.7 tamanho da propriedade e a evolução: se foi maior ou menor;

1.8 mão-de-obra e parentesco (quantos, se são membros da família e quem faz o quê).

\section{Sobre o Estado:}

2.1 o que sabe sobre a Embrapa/Embrapa Pecuária Sudeste? Qual vinculação?

2.2 O que sabe sobre a CATI? Qual vinculação?

2.3 O que sabe sobre a Secretaria Municipal da Agricultura. Qual vinculação em relação à atividade.

\section{Sobre o projeto:}

3.1 Você sabe quando surgiu este projeto?

3.2 Como? Por que/qual preocupação? Qual motivação?

3.3 Quanto tempo está vinculado ao projeto?

3.4 Você conhece a estrutura (seleção dos municípios, produtores, critérios etc)?

3.5 Qual sua responsabilidade/contribuição (você participa das decisões, é consultado sobre os próximos passos a ser seguidos ect)?

3.6 Você conhece quem são os parceiros: qual papel?

3.7 Como conheceu o projeto? O que mais considera importante?

3.8 Como aconteceu sua participação/adesão (houve resistência, quais motivações etc)?

\section{Sobre o conjunto da técnica:}

4.1 O que você acha que o conjunto desta técnica propõe?

4.2 Quais os benefícios (o que mais gosta) e os obstáculos (o que menos gosta) no emprego da técnica? Por que?

4.3 A técnica em si contribuiu positiva ou negativamente para seu desenvolvimento (autonomia, independência financeira/decisão, participação etc)?.

4.4 Qual a relação com as práticas tradicionais do produtor? Elas vêm no sentido de valorizar ou suplantar técnicas tradicionais. Como era feito antes/o que acha agora?

4.5 Quais fatores que interferem na adoção/resistência? Em relação ao produtor e em relação ao extensionista.

4.6 Como a técnica, quando da sua adoção, contribui para a relação: tecnologia $X$ produtividade $\mathrm{X}$ rentabilidade? Visto em comparação com o estágio anterior (o que aconteceu com os ganhos/custos, tempo livre etc). 
4.7 Existe na técnica algo que, embora não haja ganho de produtividade ou rentabilidade, mas que produza ganhos ambientais que valha a pena utilizá-la?

4.8. Como a técnica ajudou no controle sanitário/saúde humana.

\section{Sobre o mercado:}

4.1 Dentro da visão da cadeia produtiva (adesão cooperativas, certificação, legislação, ganho mercado nacional/internacional, acesso fornecedor/comprador etc), em que sentido o conjunto da técnica favorece ou incentiva a atividade produtiva?

$4.2 \bigcirc$ que o conjunto da técnica contribui para a sustentabilidade (relação à certificação, legislação, controle sanitário)/continuidade da atividade (se existem outras atividades rurais que, por mais que a técnica dê vantagens ao produtor, ele está sempre seduzido a migrar para outra atividade - biomassa, energia, outro tipo de alimento).

\section{Sobre a ocupação de mão-de-obra:}

6.1 Em que medida o conjunto da técnica contribui com a redução do esforço físico, da redução da jornada de trabalho, redução do contato com as condições do ambiente (intempéries, ambientes adversos, sujeito à contaminação saúde humana)?

6.2 Como o conjunto da técnica influencia nas formas de organização da rotina do trabalho, suas fases, no conjunto de trabalhadores envolvidos (+ gente - gente). Inclusão/exclusão/novos postos: como?

6.3 Como o conjunto da técnica amplia ou reduz a participação dos membros da família no trabalho rural. Qual importância dessa participação?

6.4 A nova forma de trabalho que o conjunto da técnica requer, incita ou eleva o estímulo do produtor em relação a suas atuais tarefas ou reduz este estímulo? Por que, como ele se sente?

\section{Sobre a propriedade:}

7.1 Como o conjunto da técnica contribuiu para a permanência na propriedade ou se o produtor teria que se desfazer dela e adquirir mais terra ou menos terra para permanecer na atividade.

7.2 Como o conjunto da técnica favorece a melhoria da gestão da unidade produtiva?

7.3. O modelo de gestão requerido, para o conjunto da técnica, se torna um impedimento ou é motivo de resistência para a adoção da técnica?

7.4 Como o conjunto da técnica ajuda na obtenção mais rápida dos resultados: o que interfere?

7.5 condições de deslocamento/mobilidade; em relação ao produto: consumidor, cooperativa, fornecedor (qual regularidade)

7.6 relações de vizinhança: como se dá? Se estão identificados do que produzem e da forma como fazem, eles aderiram a técnica e a CATI

7.7 Participação em eventos sociais/viagem que dizem respeito a congressos, exposições que ajudam na atividade produtiva.

\section{Perguntas para o produtor sem vínculo:}

8.1 Como são as coisas que o senhor faz agora, qual mercado, quais as técnicas que o senhor tem mesmo, de quem adquiriu e com isso o que faz; de que forma acessa o mercado, com relação à propriedade e o trabalho? 